VINICIUS DE ANDRADE OLIVEIRA

ÁCIDOS GRAXOS DE CADEIA CURTA,

PRODUTOS DO METABOLISMO DA MICROBIOTA INTESTINAL,

PROTEGEM DA LESÃO RENAL AGUDA

Tese apresentada ao Programa de Pós-Graduação em Imunologia do Instituto de Ciências Biomédicas da Universidade de São Paulo, para obtenção do Título de Doutor em Ciências 


\section{ÁCIDOS GRAXOS DE CADEIA CURTA, PRODUTOS DO METABOLISMO DA MICROBIOTA INTESTINAL, PROTEGEM DA LESÃO RENAL AGUDA}

Tese apresentada ao Programa de Pós-Graduação em Imunologia do Instituto de Ciências Biomédicas da Universidade de São Paulo, para obtenção do Título de Doutor em Ciências

Área de concentração: Imunologia

Orientador: Prof. Dr. Niels Olsen Saraiva Câmara

Versão original 
DADOS DE CATALOGAÇÃO NA PUBLICAÇÃO (CIP)

Serviço de Biblioteca e Informação Biomédica do

Instituto de Ciências Biomédicas da Universidade de São Paulo

reprodução não autorizada pelo autor

Oliveira, Vinicius de Andrade.

Ácidos graxos de cadeia curta, produtos do metabolismo da microbiota intestinal, protegem da lesão renal aguda / Vinicius de Andrade Oliveira. -- São Paulo, 2014.

Orientador: Prof. Dr. Niels Olsen Saraiva Câmara.

Tese (Doutorado) - Universidade de São Paulo. Instituto de Ciências Biomédicas. Departamento de Imunologia. Área de concentração: Imunologia. Linha de pesquisa: Imunologia das doenças renais.

Versão do título para o inglês: Short chain fatty acid, a metabolism product from gut microbiota, protect from acute kidney injury.

1. Ácido graxo de cadeia curta 2. Epigenética 3 . Lesão renal aguda 4. Inflamação 5. Acetato 6. Microbiota I. Câmara, Prof. Dr. Niels Olsen Saraiva II. Universidade de São Paulo. Instituto de Ciências Biomédicas. Programa de Pós-Graduação em Imunologia III. Título. 
Candidato(a): $\quad$ Vinicius de Andrade Oliveira.

Título da Tese: $\quad$ Ácidos graxos de cadeia curta, produtos do metabolismo da microbiota intestinal, protegem da lesão renal aguda.

Orientador(a): $\quad$ Prof. Dr. Niels Olsen Saraiva Câmara.

A Comissão Julgadora dos trabalhos de Defesa da Tese de Doutorado, em sessão pública realizada a .................., considerou
( ) Aprovado(a)
( ) Reprovado(a)

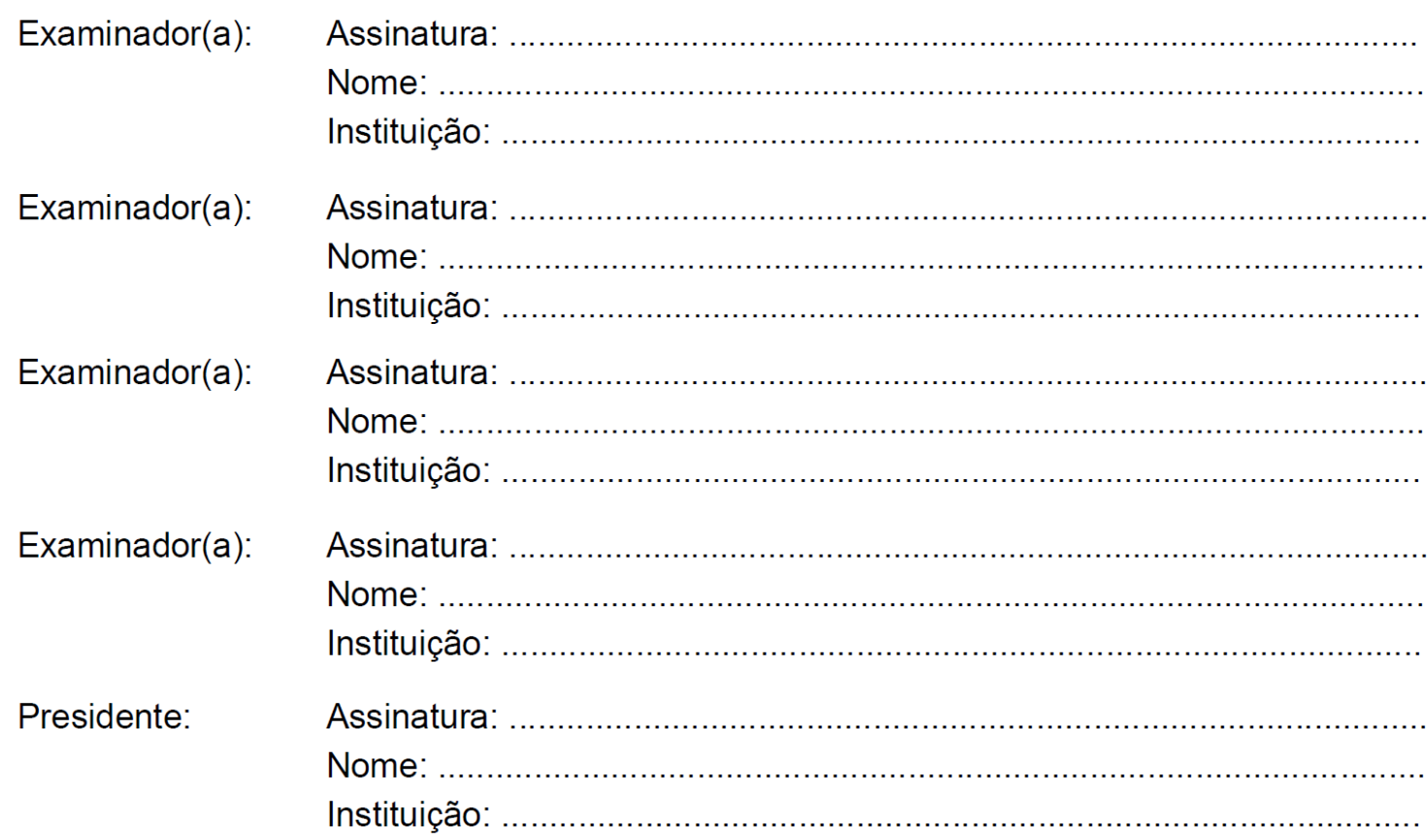




\section{Certificado}

Certificamos que o protocolo registrado sob n 121 nas fls. 109 do livro 02 para uso de animais em experimentação, sob a responsabilidade do Prof(a) $\operatorname{Dr}(a)$ ) Niels Olsen Saraiva Câmara, Coordenador (a) da Linha de pesquisa "Ácidos graxos de cadeia curta (AGCC) como moduladores da resposta inflamatória na lesão renal aguda e crônica experimental" do qual participam o(s) aluno(s) Vinícius de Andrade Oliveira, está de acordo com os Princípios Éticos de Experimentação Animal adotado pela Sociedade Brasileira de Ciência de Animais de Laboratório (SBCAL) e foi aprovado pela COMISSÃO DE ÉTICA NO USO DE ANIMAIS (CEUA) em 05.10.2011, com validade de 3 anos.

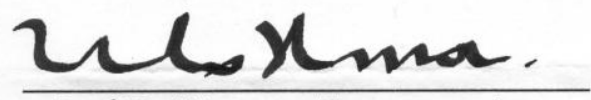

Prof.Dr.Wothan TAVARES DE LIMA Coordenador CEUA - ICB/USP
São Paulo, 10 de outubro de 2011.

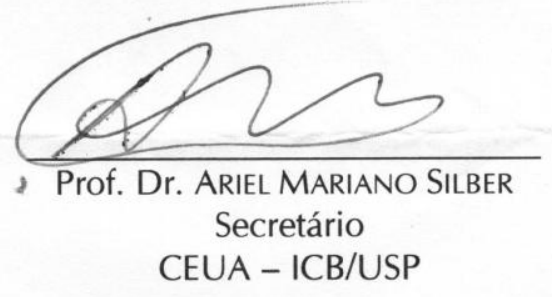


Dedico este trabalho a minha esposa Camila, aos meus pais Djalmir e Lucilene, ao meu irmãos Anderson, a minha irmã Camila (in memorian) e ao meu sobrinho Henrico . 


\section{AGRADECIMENTOS}

Ao Niels, por me mostrar o que é ser um pesquisador genial, por ter sido um grande amigo e por me dar apoio incondicional em todos os percalços fora da pós-graduação que passei. Por ter acreditado, confiado em mim como seu aluno e por me auxiliar na escrita da tese, mas principalmente, por ter sido sempre presente em grande parte do tempo no laboratório muito mais como amigo do que como chefe;

Aos amigos de laboratório Pedro, e principalmente ao meu grande amigo Ênio que já saíram do laboratório, mas que contribuíram de maneira especial para o desenvolvimento do projeto;

Aos amigos Tarcio, Reinaldo, Daniel, Angela, Danilo, Felizardo, Felipe, Pereira, Angela, Cris, Marina, Clarice, Carlinha, Andrea Rodas, Marizinha, Maristella, Marcela, Yuri, Marcelle pelo excelente convívio nestes anos de laboratório e compartilhar as frustrações;

Aos novos membros do LIT Aline, Cris Naffah, Iris, Felipe Valença, Flavia, Fernanda Terra que entenderam a atmosfera do LIT e continuam fazendo dele um lugar agradabilíssimo de trabalhar;

Ao meu grande amigo Matheus, por tudo que fez por mim no laboratório neste período, por ter me ajudado na grande parte dos experimentos, desmistificando-os. E por ouvir as minhas lamentações. Você foi o meu braço direito.

A Mariane, desde seus primeiros ensinamentos de como cultivar células dendríticas quando entrei no laboratório até sua grande contribuição para o meu desenvolvimento na pós-graduação e por também ouvir minhas lamentações, mas principalmente pelo seu rigor e senso crítico apurados, e por sua honestidade e senso de justiça ilibados.

À Meire e à Claudinha, por suas contribuições para que o laboratório estivesse sempre em condições ideais de trabalho;

Ao Milton, Otacílio e aos demais colaboradores da portaria, pela alegria com que recebem as pessoas fazendo você chegar e sair sorrindo, mesmo quando os dias não caminhavam para tal; 
A todos os Profs do departamento de imunologia que contribuíram para o meu crescimento intelectual e me mostraram o caminho para que um dia eu possa me tornar um imunologista;

À Maria Eni, por sempre me lembrar de datas e prazos e me auxiliar com todos os trâmites da pós-graduação;

Aos colaboradores do CEFAP Fernando e Mário, ao Israel e ao Paulo Albe, por contribuírem para que este trabalho pudesse acontecer;

Ao Prof Jonathan Powell, pelo período de estágio em seu laboratório, e por ser um cientista entusiasmado;

À minha esposa, que foi a pessoa que mais participou das minhas frustrações e também abdicou de muitas coisas para que eu pudesse me dedicar ao projeto e à pósgradução, obrigado pela compreensão;

A meus pais e irmão e sobrinho que sempre me apoiaram e acreditaram em mim, ainda que eu tenha estado ausente em muitas ocasiões;

E finalmente a Deus, por me proteger, me dar saúde e sabedoria para tentar trilhar o caminho das melhores escolhas. 


\section{APOIO FINANCEIRO}

Este trabalho recebeu auxílio da Fundação de Amparo a Pesquisa do Estado de São Paulo (FAPESP)

Processo: 2011/01016-2 
"Talvez não tenha conseguido fazer o melhor, mas lutei para que o melhor fosse feito. Não sou o que deveria ser, mas Graças a Deus, não sou o que era antes".

(Marthin Luther King) 


\section{RESUMO}

Oliveira VA. Ácidos graxos de cadeia curta, produtos do metabolismo da microbiota intestinal, protegem da lesão renal aguda. [tese (Doutorado em Imunologia)]. São Paulo: Instituto de Ciências Biomédicas, Universidade de São Paulo; 2014.

Introdução: Os ácidos graxos de cadeia curta (AGCC) são produtos liberados a partir da fermentação de carboidratos complexos pela microbiota intestinal. Eles possuem papéis antiinflamatórios e ação inibitória sobre histona deacetilases. A lesão renal aguda (LRA) é caracterizada por uma inflamação renal que influencia a função do rim. Assim, nós formulamos a hipótese de que os AGCC melhorariam os desfechos da LRA ao modular o processo inflamatório, por mecanismos epigenéticos ou não. Objetivo: projeto avaliou se o tratamento com os AGCC impactaria positivamente ou não nos desfechos inflamatórios da LRA. Métodos. Camundongos ( $\mathrm{n}=5$ por grupo, em cada experimento) foram submetidos a dois modelos de LRA, o induzido por isquemia e reperfusão renal (IRI) e outro por sepse polibacteriana. Os AGCC foram dados individualmente $(200 \mathrm{mg} / \mathrm{kg}), 30$ minutos antes da isquemia e no momento da reperfusão. No modelo de sepse polimicrobiana, os camudongos foram tratados com acetato $(400 \mathrm{mg} / \mathrm{kg}$ ) um dia antes, no momento e $6 \mathrm{~h}$ após a cirurgia. Após 24h, foram coletadas amostras para análises protéicas, gênicas e bioquímicas. Em um grupo específico, bactérias produtoras de acetato foram usada como ferramentas terapêuticas. Células dendríticas foram pré-tratadas com acetato e estudadas em relação ao fenótipo e função durante ativação. Estresse oxidativo foi estudado num modelo in vitro de hipóxia em células tubulares. Um valor de $\mathrm{p}$ foi considerado significativo quando $\leq 0,05$. Resultados. AGCC diminuíram os níveis séricos de creatinina e ureia após IRI ( $p<0,0001)$. Esta melhora foi associada a menores expressões de moléculas pró-inflamatórias no rim e sistemicamente. Redução no influxo de células inflamatórias, diminuição da ativação da via do NF-kB e menor taxa de apoptose também foram observadas nos animais tratados. Além disso, foi verificado que o tratamento com acetato diminuiu a atividade de histona deacetilase e modulou a expressão de genes relacionados à modificação da cromatina. Administrando bactérias produtoras de acetato, foi possível observar um aumento da concentração do acetato e uma proteção da LRA, junto de uma menor inflamação sistêmica In vitro, verificouse que o tratamento com os AGCC modularam a ativação das células dendríticas e inibiram a proliferação de linfócitos. Em células epiteliais renais submetidas à hipóxia ou a um estímulo inflamatório, os AGCC reduziram a produção de espécies reativas de oxigênio, diminuindo os efeitos da hipóxia e também a ativação de NF-кB. Já no modelo de sepse, a presença do acetato promoveu uma melhora da função renal e diminuiu os níveis de moléculas próinflamatórias sistemicamente, bem como o infiltrado inflamatório no lavado peritoneal. Conclusão. AGCC modulam processos inflamatórios no rim via ações epigenéticas ou não, podendo ser considerado como uma ferramenta promissora na proteção da LRA.

Palavras-chave: Ácido graxo de cadeia curta. Epigenética. Lesão renal aguda. Inflamação. Acetato. Microbiota. 


\begin{abstract}
Oliveira VA. Short chain fatty acid, a metabolism product from gut microbiota, protect from acute kidney injury. [Ph. D. thesis (Immunology)]. São Paulo: Instituto de Ciências Biomédicas, Universidade de São Paulo; 2014.

Introduction: The short-chain fatty acids (SCFA are products released from the fermentation of complex carbohydrates by intestinal microbiota. They have antiinflammatory and histone deacetylases inhibition properties. Acute kidney injury (AKI) is characterized by a kidney inflammation which is strongly associated with kidney function. Thus, immune system cells have been classically related to the inflammatory process in the LRA. Thus, we hypothesized that SCFA could improve the outcomes of AKI by modulating the inflammatory process, by epigenetic mechanisms or not. The objective of this project was to evaluate whether treatment with the SCFA could improve AKI. Methods. Mice $(n=5$ per group in each experiment) were subjected to two models of AKI, being one induced by ischemia and reperfusion and another from sepsis. Dosages of the SCFAs were given alone (200 mg / kg) 30 'before ischemia and during reperfusion. In polymicrobial sepsis model, mice were treated with acetate $(400 \mathrm{mg} / \mathrm{kg}$ ) the day before, at the time and 6 hours after surgery. After 24 hours, samples were collected for protein, genetic and biochemical analyzes. A p value was considered significant when $\leq 0.05$. Results. Treatment with SCFA decreased serum levels of creatinine and urea after ischemia and reperfusion compared with the untreated group ( $\mathrm{p}<0.0001)$, the best protection was observed with treatment with acetate. This improvement was associated with lower protein levels of inflammatory molecules. A reduction in the influx of immune cells was also observed in animals treated with acetate. The systemic inflammatory response was also decreased in treatment with acetate. Together, these data were corroborated by a decrease in the activation of the NF-kB and lower rate of apoptosis in the kidneys of animals treated with acetate. Furthermore, it was found that treatment with acetate decreased the activity of histone deacetylase whereas modulated the expression of genes related to chromatin modification. Giving to mice acetate-producing bacteria was possible to observe an increase in the concentration of acetate and a protection from AKI along with a lower systemic inflammation. In vitro, it was found that treatment with SCFAs modulate the activation of dendritic cells and inhibit lymphocyte proliferation. In renal epithelial cell line subjected to hypoxia or to an inflammatory stimulus, the treatment reduced the production of reactive oxygen species, decreasing the effects of hypoxia and also the activation of NF-kB, respectively. In the sepsis model, the presence of acetate promoted an improvement of renal function, and decreased levels of pro inflammatory molecules systemically as well as the inflammatory infiltrated in the peritoneal cavity. Conclusion. AGCC modulates inflammatory processes in the kidney via epigenetic modificatons, could be considered as a promising tool in the protection of the AKI.
\end{abstract}

Keywords: Short chain fatty acid. Epigenetics. Acute kidney injury. Inflammation. Acetate. Microbiota. 


\section{LISTA DE FIGURAS}

Figura 1. Esquema de tratamento dos camundongos no modelo de lesão de isquemia e reperfusão (IRI) renal bilateral

Figura 2. Função renal dos camundongos submetidos à IRI renal e tratados com os AGCC.

Figura 3. Função renal e de parâmetros inflamatórios nos camundongos tratados com os AGCC sem IRI renal.

Figura 4. Necrose tecidual, níveis de citocinas, quimiocinas e do estresse oxidativo na IRI após o tratamento com o acetato

Figura 5. Nível de mRNA de moléculas pró-inflamatórias e de marcadores celulares e ativação da via de sinalização $\mathrm{NF}-\kappa \mathrm{B}$

Figura 6. Avaliação do infiltrado de leucócitos no rim em camundongos submetidos à IRI renal e tratados com acetato.

Figura 7. Níveis de expressão gênica de receptores da imunidade inata e de seus ligantes endógenos

Figura 8. Avaliação do grau de apoptose e de proliferação celular e do conteúdo de DNA mitocondrial.

Figura 9. Nível de expressão gênica dos receptores para os

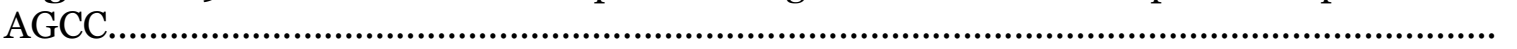

Figura 10. Avaliação da expressão de genes relacionados com modificação epigenética, da atividade da histona deacetilase e do perfil de metilação

Figura 11. Avaliação do tratamento com AGCC na maturação de células dendríticas derivadas da medula óssea.

Figura 12. Avaliação da proliferação de esplenócitos in vitro na presença dos AGCC......

Figura 13. Proliferação de células $\mathrm{CD} 4+$ e CD8+ em um contexto alogênico quando cocultivadas com células apresentadoras de antígenos tratadas com AGCC.

Figura 14. Avaliação da inflamação em linhagem de células epiteliais renais. Figura 15. Hipóxia em células epiteliais tratadas com AGCC. epiteliais tratadas

Figura 16. Análise de ativação de HIF-1a, expressão de VEGF e dosagem de lactato.

Figura 17. Tratamento com próbiotico Bifidobacterium longum (BL) e Bifidobacterium adolescentis (BA) aumenta os níveis de acetato sem prejudicar a função renal. 
Figura 18. Tratamento com próbiotico Bifidobacterium longum (BL) e Bifidobacterium adolescentis (BA) protege os animais da IRI............................................

Figura 19. Função renal e sobrevida nos camundongos tratados com acetato e

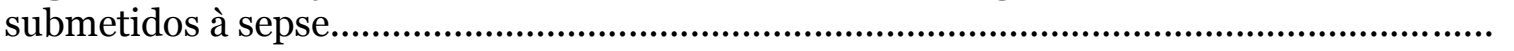

Figura 20. Níveis de citocinas sistemicamente e do infiltrado na cavidade peritoneal e no rim dos animais submetidos à sepse e tratados com acetato 


\section{LISTA DE ABREVIATURAS E SIGLAS}

$7 \mathbf{T M}$ - 7 trasmembrane receptor

AGCC - ácidos graxos de cadeia curta

ATCC - American Type Culture Collection

ATG - autophagy related protein

BM-DC - células dendríticas derivadas da medula óssea

DRC - Doença renal crônica

ERO - Espécie reativa de oxigênio

FID - Flame ionization detector

GPCR - receptores acoplados à proteína-G

GSH - glutationa reduzida

GSSG - glutationa oxidada

HDAC - histone deacetilase

HIF-1a - Hypoxia inducible factor

IRA - Insuficiência renal aguda

IRI - lesão de isquemia e reperfusão

$\mathbf{K O}-$ knockouts

LRA - Lesão renal aguda

NLRP6 - NOD-like receptor family pyrin domain containing 6

NO - óxido nítrico

OVA - ovalbumina

PBMC - peripheral blood mononuclear cells

SBF - bactéria filamentosa segmentada

TEM - Transição epitélio-mesenquimal 
Th1 - T helper do tipo 1

Th17 - T helper do tipo 17

Th2 - T helper do tipo 2

Tregs - células T reguladoras 


\section{SUMÁRIO}

1 INTRODUÇÃo.

1.1 Insuficiência Renal Aguda.

1.2 Microbiota intestinal, resposta imune e doença renal rim.

1.3 Ácidos graxos de cadeia curta (AGCC), receptores acoplados à proteína- G e a resposta inflamatória.

2.1 Gerais

2.2 Específicos.

3 MATERIAL E MÉTODOS.

3.1 Camundongos

3.2 Indução da lesão renal através da lesão de IRI e séptica e tratamento com os AGCC.

3.3 Avaliação histológica do tecido renal.

3.4 Cultivo e administração dos probióticos Bifidobacterium longumm e Bifidobacteruim adolescentis.

3.5 Geração/maturação de células dendríticas derivadas da medula óssea (BMDC).

3.5.1 Co-cultivo de células pré-tratadas com AGCC e esplenócitos de camundongos Balb/c para análise da proliferação frente a um estímulo aloespecífico.

3.6 Dosagens dos Ácidos graxos de Cadeia Curta. 
3.8 Modelo de hipóxia em linhagem de células tubulares renais

3.9 Extração do RNA, Transcrição Reversa, Real-time PCR e PCRarray.

3.10 Avaliação da função renal pelos níveis de ureia e creatinina.

3.11 Dosagem de glutationa reduzida e oxidada.

3.12 Bioplex.

3.13 Avaliação da apoptose 36

3.14 Imunohistoquímica.

3.15 Citometria de fluxo.

3.15.1 Análise das células dendríticas derivadas da medula óssea

3.15.2 Análise da fosforilação de $N F-k B$ em linhagem de célula tubular renal.

3.16 Produção de óxido nítrico.

3.17 Western Blot.

3.18 Microscopia confocal e medida de lactato

3.19 Detecção da Mieloperoxidase (MPO) no tecido renal.

3.20 Ensaio da atividade de histone deacetilase (HDAC)

3.21 Avaliação do status global de metilação do DNA nas amostras de tecido renal e do conteúdo de DNA mitocondrial.

3.22 Análise estatística

4.1 Tratamento dos animais com AGCC na IRI.

4.2 Avaliação, da necrose tecidual, do estado inflamatório local e sistêmico e do estresse oxidativo nos camundongos submetidos à IRI renal e tratados com acetato.

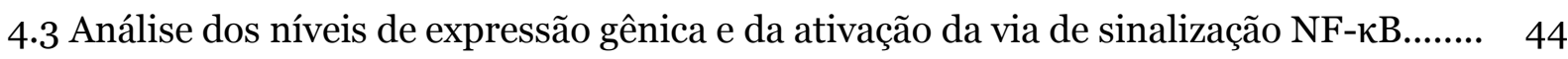

4.4 Avaliação do infiltrado de leucócitos celular nos camundongos tratados com acetato.. 
4.6 Avaliação da apoptose e da proliferação/regeneração tecidual e conteúdo de DNA mitocondrial.

4.7 Expressão dos receptores para AGCC no tecido renal

4.8 Avaliação da metilação do DNA, expressão gênica de moléculas envolvidas na modificação da cromatina e da atividade de histona deacetilase no tecido renal.

4.9 Avaliação do tratamento de AGCCs na maturação de células dendríticas derivadas da medula óssea

4.10 Avaliação da capacidade proliferativa de esplenócitos frente a um estímulo específico e a um estímulo policlonal.

4.11 Avaliação na modulação da maturação das células apresentadoras de antígenos pelos AGCCs na sua capacidade de induzir a proliferação de células alogênicas

4.12 Avaliação da inflamação em linhagem de célula epitelial renal após o tratamento com os AGCC.

4.13 Avaliação do processo de hipóxia, da ativação de HIF-1a e da produção de lactato em células epiteliais renais

4.14 Administração dos probióticos Bifidobacterium longum e Bifidobacterium adolescentis na LRA.

4.15 Avaliação da lesão renal secundária à sepse em camundongos tratados com acetato. 62

4.16 Avaliação da inflamação sistêmica, do infiltrado inflamatório no lavado peritoneal e no rim dos camundongos submetidos à sepse...

6 CONCLUSÕES

APÊNDICE - Trabalhos publicados no doutorado 
1 INTRODUÇÃO 


\subsection{Lesão Renal Aguda}

A lesão renal aguda (LRA) é uma desordem caracterizada por uma abrupta deterioração da função renal que prejudica a homeostasia metabólica, o balanço eletrolítico e dos fluídos por um período de horas a dias, e pode ser originada por causas diversas, como drogas e perdas volêmicas (1-4). A importância clínica da LRA é exemplificada com dados mostrando consistente associação da LRA e aumento do risco de piores desfechos para o paciente, como morte, doença renal crônica (DRC) e, em segundo plano, maior utilização de recursos públicos (5). Não à toa, a LRA vem sendo considerada como um preocupante problema de saúde global (4). A prevalência de LRA em pacientes internados está entre 6$19 \%$, e sua taxa de mortalidade entre esses pacientes está entre 40-70\% (6, 7). Uma revisão sistemática recente da literatura, na qual se incluiu 49 milhões de pacientes (a maioria de países ricos) apontou que um em cada cinco adultos e uma em cada três crianças hospitalizadas com enfermidades agudas desenvolvem LRA (8).

O desenvolvimento da LRA origina-se a partir da lesão de isquemia e reperfusão (IRI) e da lesão secundária à sepse. O mecanismo de IRI envolve a lesão isquêmica, na qual ocorre a depleção de ATP nas células epiteliais e endoteliais no rim, juntamente com liberação de moléculas que contribuirão para a defosforilação do ATP em ADP, exacerbando a deficiência deste último, o que diminui ainda mais a energia para as células $(9,10)$. Esta depleção de ATP também ocorre porque as mitocôndrias, que são as principais fontes para geração de ATP, na lesão de IRI sofrem encurtamento e fragmentação, perdendo o seu potencial de membrana. Isto acarreta em uma menor respiração celular e maior produção de espécie reativa de oxigênio (ERO), culminando com uma maior morte celular apoptótica via mitocondrial (11). As ERO reagem com diversas regiões e moléculas das células, como membrana plasmática e proteínas, causam dano no DNA e fazendo que a célula libere componentes endógenos que ativarão receptores da imunidade inata (12). As células endoteliais também são ativadas aumentando a expressão de moléculas de adesão, que facilitarão o recrutamento leucocitário, culminando com dano tecidual após a reperfusão (13). Células dendríticas também são grandes produtoras de TNF no início da IRI, o que contribui tanto para o processo inflamatório quanto para a morte apoptótica independente da mitocôndria (14). Portanto, na lesão isquêmica pode ocorrer tanto a morte apoptótica pela via extrínseca (TNF) como pela via intrínseca (mitocôndria). Na lesão agravada pela reperfusão, além da ativação das células dendríticas, ocorre o recrutamento de neutrófilos, que quando ativados também liberam ERO $(3,13)$.

Modelos experimentais de IRI já demonstraram a importância de subpopulações de células mononucleares como linfócitos $\mathrm{T}$ e linfócitos $\mathrm{B}$, macrófagos e polimorfonucleares (neutrófilos) como contribuidores nesta lesão (14-18). Ambas as lesões, isquêmica e de 
reperfusão, culminam com o dano tecidual (13). Trabalhos do nosso grupo também demonstraram que na lesão IRI renal ocorre participação das células T regulatória (19), de citocinas como IL-12 e IFN- $\gamma$, responsáveis pela polarização das células T CD4+ para T helper do tipo 1 (Th1) $(20,21)$, e que os tratamentos com inibidores das ciclooxigenases (22) e com antagonistas para receptores de bradicinina do tipo 1 (23) seriam benéficos para lesão. Outros fatores e componentes como idade, vitamina E (24) e a suplementação combinada de magnésio e N-acetilcisteína (25) são fatores que podem proteger o órgão da LRA, demonstrando que a ela é uma entidade multifatorial, onde muitos mecanismos estão envolvidos em seu processo.

A LRA é uma doença sistêmica e o nosso grupo também observou que a IRI renal induz inflamação no pulmão, com aumento na produção de citocinas inflamatórias e da reatividade pulmonar (26). De fato, a ocorrência de LRA está relacionada a lesões em outros órgãos, dentre os quais coração, fígado e cérebro $(17,27)$. O mecanismo de lesão nos diversos órgãos não é bem estabelecido, mas sabe-se que a liberação de citocinas pró-inflamatórias, mediadores lipídicos, bradicinina e de ERO oriundas da LRA são mediadores importantes nas disfunções em outros órgãos $(17,27)$.

Outra causa freqüente de LRA em pacientes hospitalizados é a secundária a sepse. No ambiente de terapia intensiva, a sepse tem se tornado a principal causa de IRA, sendo que a dupla ocorrência, de sepse e de LRA, eleva as taxas de mortalidade em 70 \% (28). A sepse resulta de uma amplificação da resposta do hospedeiro frente uma infecção que se torna desregulada e tem como principal agente etiológico as bactérias (29). Os mecanismos de LRA secundária a sepse ainda não são esclarecidos, mas os mediadores resultantes do processo amplificado de resposta à infecção como liberação de citocinas pró-inflamatórias, ROS, substâncias vasoativas, são apregoados como participantes do processo de lesão renal secundária a sepse (30).

As consequências da LRA também são particularmente visíveis no transplante renal, onde a LRA presente em órgãos oriundos de receptores de doador falecido (clinicamente conhecida como função retardada do enxerto), é fator de risco para eventos adversos póstransplante como pior sobrevida do enxerto a curto e longo prazo $(31,32)$.

Recentemente, alguns estudos experimentais e clínicos vêm demonstrando que os eventos desencadeados na LRA podem contribuir para o desenvolvimento da DRC, com o aparecimento de componentes característicos de cronicidade (33-35). A produção de citocinas pró-inflamatórias, pró-fibróticas e ERO pelas células residentes no rim e pelo infiltrado leucocitário, após um dano agudo severo, ativam as células mesangiais, fibroblastos e células tubulares a produzirem grande quantidade de componentes de matriz extracelular como colágeno e fibronectina. Esses componentes depositam-se continuamente no compartimento extracelular e, juntamente com a deficiência na degradação desses 
componentes, resulta na modificação da arquitetura do parênquima renal por fibrose e conseqüente perda da função renal (36-38). Outro evento importante desencadeado pela LRA é a transição epitélio-mesenquimal (TEM), na qual ocorre a transformação das células epiteliais em miofibroblastos. Esse processo é regulado por diversos fatores frequentemente combinados, entre os quais estão fatores de crescimento, citocinas e hormônios (39). A TEM ocorre em algumas etapas essenciais como: 1) perda de propriedades adesivas, 2) expressão de novo de a-SMA e reorganização de actina, 3) ruptura da membrana basal glomerular e 4) aumento da migração e invasão celular. Essas etapas juntamente com a proliferação dos fibroblastos no rim resultam na produção de moléculas pró-fibróticas tais como colágenos do tipo I e III e fibronectina, que são depositadas progressivamente no parênquima renal, prejudicando a funcionalidade do órgão. A sinalização via TGF- $\beta$ está entre as principais vias de indução e de manutenção da TEM $(37,39)$. No entanto, um elegante trabalho pôs em cheque a presença de TEM após o dano isquêmico. Yang e colegas observaram que o dano agudo também acarretava no aumento de células epiteliais tubulares com ciclo celular interrompido na fase G2/M. Essas células produziriam fatores pró-fibróticos que agiriam em células de origem mesenquimal presentes no interstício renal, promovendo a síntese de colágeno (35).

Embora haja grande conhecimento acerca do mecanismo da lesão renal que culmina na IRA através de estudos experimentais, as intervenções farmacológicas em humanos não têm obtido mesmo êxito que os observados em camundongos (40). Portanto, o avanço no conhecimento de novos mecanismos fisiopatogênicos envolvidos na lesão é de grande importância para a prevenção e ou diminuição da lesão, com consequente benefício à população de pacientes hospitalizados.

1.2 Microbiota intestinal, resposta imune e doença renal rim

A microbiota intestinal é a composição das bactérias que habitam os intestinos delgado e grosso e pode ser considerada saudável (simbiótica) ou patogênica (disbiótica) (41). Trabalhos têm buscado compreender a influência da microbiota intestinal na resposta imune e vice-versa. Até o momento, estas relações entre microbiota e resposta imune estão sempre relacionadas à disbiose. Porém, não está estabelecido quem é causa ou consequência. Por exemplo, camundongos knockouts (KO) para o gene NLRP6 (do inglês, NLR family, pyrin domain containing 6, também conhecido como NALP6) do sistema imune inato estão associados ao desenvolvimento de colite severa espontaneamente (42), podendo transferir este fenótipo para animais germ-free ou selvagem simplesmente através da transferência da microbiota. Neste caso, há um indício de que o sistema imune pode influenciar na composição da microbiota intestinal. Também, moléculas ou determinados tipos de bactéria 
podem aumentar diferentes tipos de células do sistema imune. A molécula PSA da B. fragilis está associada com aumento das células Foxp3+ (células T reguladoras -Tregs- produtoras de IL-10)(43), bem como um coquetel de várias espécies de Clostridium também aumenta a frequência de Tregs e induzem os níveis de IgE após estímulos favoráveis a indução do padrão Th2 (44). Por outro lado, bactéria filamentosa segmentada (SBF) induz células do padrão Th17 (45).

O sistema imunológico no intestino é regulado por diversas moléculas antibacterianas como REgIIIY, que se acopla às bactérias e evita que elas adiram as células epiteliais intestinais (46). Outras moléculas como as defensinas também possuem papel semelhante (47). Além disso, células B na lâmina própria podem ser ativadas nas placas de Payer por células dendríticas e ou macrófagos que capturaram bactérias que conseguiram atravessar a parede intestinal e esta interação induz a produção de moléculas de IgA por plasmócitos, que por sua vez, serão secretadas para a luz intestinal e servirão como neutralizantes, também evitando que essas bactérias rompam a barreira epitelial intestinal (48). O sistema imune da mucosa também limita a resposta ao tecido linfoide, não o espalhando a outros órgãos linfoides periféricos porque as células dendríticas e macrófagos possuem receptores para homing nos tecidos linfoides intestinais, evitando inflamação sistêmica (48).

Ainda que o avanço esteja ocorrendo rapidamente em relação ao entendimento das interações entre o sistema imune e a microbiota intestinal, pouco é sabido da repercussão em outros órgãos quando ocorre esta mudança.

A mais conhecida associação entre microbiota e doença renal vem da presença no intestino da bactéria gram negativa Oxalobacter formigenes e a ocorrência de nefrolitíase pelo oxalato de cálcio $(49,50)$. Ainda, estudos experimentais mostram que camundongos germ-free são susceptíveis a LRA induzida por isquemia reperfusão (51) enquanto que a composição da microbiota intestinal também tem sido associada com a proteção da nefropatia causada por IgA (52).

Nos últimos dois anos, novos dados têm surgido associando a composição da microbiota intestinal à barreira intestinal e à DRC $(53,54)$. Neste contexto a DRC pode produzir moléculas (toxinas urêmicas) que caem na corrente sanguínea e no intestino, influenciando na barreira intestinal e também na composição da microbiota, permitindo a entrada de bactérias patogênicas na corrente sanguínea e potencializando o processo inflamatório.

Além da composição da microbiota, metabólitos produzidos por essas bactérias, como os ácidos graxos de cadeia curta (AGCC) também tem funções em doenças intestinais e atuam diretamente na modulação de células do sistema imune, como inibição da proliferação de linfócitos e modulação da ativação de células dendrítica (55-58). Esses metabólitos podem ser modificados pela simples mudança na ingestão de alimentos. Além disso, a utilização de 
espécies específicas de bactéria produtoras de AGCC pode servir como forma alternativa para a utilização terapêutica. Recentemente foi reportado que a administração de bactéria do gênero Bifidobacterium aumenta a concentração de acetato no intestino(59). Este maior nível de acetato foi benéfico em modelo de infecção enterohemorrágica por E.coli fazendo com que os camundongos tivessem maior sobrevida. Estas bactérias aparentemente possuem uma ilha em seu genoma que codifica transportadores de carboidratos, o que facilitaria a captação e consequente produção de AGCC (6o). Entretanto, até o momento não se tem descrito o uso desta estratégia para tratamentos em outros modelos de doença além do intestino.

1.3 Ácidos graxos de cadeia curta (AGCC), receptores acoplados à proteína-G e a resposta inflamatória

Os AGCC são produtos finais da fermentação de carboidratos produzidos pela microbiota intestinal, constituídos por cadeia alifática contendo até 6 carbonos. Os AGCC mais abundantes encontrados no intestino são o acetato, propionato e o butirato e sua produção no intestino está relacionada a diversas funções intestinais como motilidade e absorção, além de servir como fonte de energia para os colonócitos (61). Além da sua grande contribuição no intestino, os AGCC podem tomar rapidamente a corrente sanguínea (62), mas a sua repercussão em outros órgãos e doenças ainda encontra-se em fase inicial de investigação. Os AGCC se ligam aos receptores GRP41 e 43 (63-65). Também ocorre uma ordem de potência de ativação em relação ao AGCC, sendo que o GPR43 é ativado igualmente por acetato, propionato e butirato, sendo estes maiores que pentanoato, hexanoato e formiato, ao passo que GPR41 possui ordem diferente de potência de ativação, na qual a maior potência de ativação é ordenada como segue: propionato $=$ pentanoato $=$ butirato $>$ acetato $>$ formiato (63).

Os receptores acoplados à proteína-G (GPCRs), também conhecidos atualmente como 7TM (do inglês, 7 trasmembrane receptor) são formados por 5 famílias e possuem aproximadamente 800 membros conhecidos. Os GPCRs estão localizados na membrana plasmática e possuem uma estrutura composta de sete domínios transmembrânicos, interligados por domínios intra e extracelulares, podendo ser ativados por diversos ligantes, entre os quais aminoácidos, ácidos graxos e neurotransmissores (66). Os GPCRs são alvos potenciais, pois um terço de todas as terapias atuais é direcionado a eles. Muitos deles ainda são descritos como órfãos, pois não possuem ligantes descritos. Entretanto, para alguns receptores já foram descritos ligantes específicos (66). Um subconjunto desses receptores, o GPR41-43, são receptores dos AGCC.

O GPR40 possui como ligantes os ácidos graxos de cadeia longa (64). Ele está expresso em células $\beta$ do pâncreas e está envolvido com a secreção de insulina, mas também 
pode ser expresso em células do sistema imune (67). Já os receptores GPR41, também expresso no tecido adiposo, e o GPR43 estão expressos em células do sangue periférico (PBMC), como neutrófilos, monócitos e linfócitos $(63,65,67,68)$. Ainda, não há na literatura dados sobre a regulação da expressão desses receptores em rins em condições de isquemia, de inflamação e na sepse.

Estudos demonstraram que os AGCC, principalmente o butirato, estão envolvidos em diferentes frentes como na liberação de ERO, na fagocitose dos neutrófilos e na migração deles para sítios inflamatórios (69, 70) em parte mediada pelo GPR43 (71), nas inibições da proliferação e da produção das citocinas IL-2 e IFN- $\gamma$ dos linfócitos in vitro (55), na diferenciação e maturação da célula dendrítica pela atividade de inibidor das histonas deacetilases (72), na secreção de leptina no tecido adiposo (73) e na apoptose de linhagens de células tumorais humanas de cólon (74). Portanto, os AGCC podem ter papel importante para a resposta inflamatória presente na LRA experimental, de forma direta ou indireta.

Alguns aspectos em relação ao uso e atuação dos AGCC ainda não estão totalmente esclarecidos. Por exemplo, em quais circunstâncias os AGCC atuariam via receptor GPRs ou como inibidor de histonas deacetilases. O que se tem acreditado que é que a atuação dos AGCC como inibidor de enzimas de deacetilação de histonas seja independente do receptor (75).

Considerando os AGCC como fonte de energia, seu metabolismo pode ser utilizado para alimentar o ciclo de Krebs, transformando o Acil-CoA, produto da $\beta$ oxidação de ácidos graxos, em acetil-CoA. Neste caso, quando houver saturação da via metabólica de $\beta$ oxidação, e esta não fosse a principal via de fonte de energia, os AGCC acumulariam nas células e atuariam como inibidores de acetilação de histonas(76). É sabido que células em proliferação como células cancerígenas e linfócitos ativados demandam mais glicólise que células em repouso. Estas células em proliferação estão sob efeito Warburg, que é quando mesmo na presença de oxigênio, o produto do metabolismo da glicose gera mais lactato em detrimento do acetil-CoA, fosforilação oxidativa e cadeia respiratória(77). Na IRI ocorre um estágio de proliferação das células tubulares para repopular as células mortas, mas ainda não foi reportado se estas células estão sob o Efeito Warburg.

Ainda, tem sido descrito que os AGCC poderiam induzir a autofagia como estratégia para retardar o processo apoptótico via mitocôndria em linhagem celular de colon(74). A autofagia é o processo que ocorre em nível basal na maioria das células, que auxilia na homeostasia celular, eliminando proteínas e organelas danificadas em condições fisiológicas ou patológicas como, por exemplo, em condições de estresse $(78,79)$. Brevemente, o processo inicia-se pela formação do fagóforo. $O$ elongamento e o fechamento do fagóforo gera $o$ autofagossomo e este por sua vez fundirá com o lisossomo e dará origem ao autofagolissomo, no qual as proteínas e organelas danificadas serão processadas (78) Este processo é mediado 
por diversas proteínas relacionadas a autofagia entre elas as ATG (autophagy related protein) envolvidas em etapas diferentes do processo (80).

Estudos funcionais sobre o receptor GPR43 demonstram que, a ativação deste por AGCC conduz a ativação celular através do aumento de mensageiros secundários como influxo de cálcio e AMP cíclico $(57,65)$. Camundongos germ-free, que produzem pouco ou nenhum AGCC, submetidos ao modelo de colite apresentam lesões mais severas, em relação aos camundongos germ-free tratados com AGCC, ou seja, o AGCC teve papel protetor em relação ao desenvolvimento da colite (57). Corroborando estes dados, camundongos geneticamente deficientes para GRP43 apresentam uma colite mais severa (57, 81), e também desenvolvem outras patologias com características inflamatórias como artrite de forma mais severa $(57,82,83)$. Os AGCC podem ter um importante papel na regulação da resposta imune neste modelo de lesão, já que a proliferação de linfócitos, presente na lesão de IRI renal, pode ser inibida pelo butirato (55).

Como a LRA oriunda da lesão de IRI e da séptica possui um importante componente inflamatório com liberação de citocinas pró-inflamatórias e ativação de neutrófilos e é considerada como fator de risco para o desenvolvimento de DRC e, por outro lado, têm sido demonstrados que os AGCC podem ter papel anti-inflamatório em diversos contextos, a nossa hipótese para o presente trabalho é que o tratamento com os AGCC diminua as lesões aguda e crônica nos modelos estudados, com preservação da função e do tecido renal via diminuição do processo inflamatório e do estresse oxidativo. 
2 OBJETIVOS 


\subsection{Geral}

Verificar se o tratamento com os ácidos graxos de cadeia curta protegem da lesão renal aguda induzida pela isquemia reperfusão e secundária à sepse.

\subsection{Específicos}

Nos modelos de LRA induzido por IRI e por sepse nos animais tratados ou não com AGCC, objetivamos:

$\checkmark$ Analisar a função renal e os parâmetros de morte e regeneração celular;

$\checkmark$ Verificar a expressão gênica e proteica de moléculas pró- e anti-inflamatórias no tecido renal e sistemicamente e a característica do infiltrado inflamatório;

$\checkmark$ Verificar se a administração de bactéria produtora de acetato pode proteger da LRA induzida pela isquemia e reperfusão, e;

$\checkmark$ Verificar a expressão de enzimas relacionadas à remodelação da cromática e o grau de metilação global nos rins;

Posteriormente, num modelo in vitro de ativação celular, intencionamos:

$\checkmark$ Verificar a capacidade dos AGCCs em modular a ativação e função das células dendríticas e a proliferação de linfócitos T CD4+ e CD8+.

Finalmente, num modelo de hipóxia celular in vitro que reproduz alguns eventos na LRA, objetivamos:

$\checkmark$ Analisar se o tratamento com AGCCs é capaz de modular a resposta celular à hipóxia. 
3 MATERIAL E MÉTODOS 


\subsection{Camundongos}

Camundongos $\mathrm{C}_{57} \mathrm{BL} / 6\left(\mathrm{H}-2 \mathrm{~A}^{\mathrm{b}}\right)$ foram adquiridos da Universidade Federal de São Paulo ( $\mathrm{n}=5$ por grupo, por experimento). As linhagens animais Balb/c, RAGKO, OT-II (animais com células T CD4 com TCR transgênico específico para ovabulmina, OVA) utilizadas no estudo foram adquiridas no biotério do Departamento de Imunologia, do Instituto de Ciências Biomédicas da Universidade de São Paulo (ICB/USP). Todos os animais foram mantidos em caixas adequadas e tiveram acesso à comida e a água ad libitum. Todos os procedimentos foram submetidos à aprovação junto ao comitê de ética para uso de animais da Universidade de São Paulo (n ${ }^{\circ} 121$ fls. 109 livro 02).

3.2 Indução da lesão renal através da lesão de IRI e séptica e tratamento com os AGCC

Os animais foram anestesiados com uma injeção intraperitoneal de Quetamina (100 $\mathrm{mg} / \mathrm{kg}$ ) e Xilazina (10 mg/kg) (Agribands do Brasil, São Paulo, Brasil). Uma incisão mediana foi realizada e os pedículos renais foram ocluídos com clampes para interrupção do fluxo sanguíneo por 45 minutos (tempo de isquemia). Durante este período, os animais foram hidratados com salina $0.9 \%$ e tiveram mantida constante sua temperatura $\left(\sim 37^{\circ} \mathrm{C}\right)$. Após os grampos microcirúrgico terem sido removidos, o abdome foi fechado. Os animais controles foram submetidos apenas ao processo cirúrgico, sem a interrupção do fluxo sanguíneo.

Para obtenção do modelo de LRA secundária a sepse foi realizada uma laparotomia com incisão de aproximadamente $1 \mathrm{~cm}$ e subseqüente exposição e ligadura não-obstrutiva do ceco, abaixo da válvula íleo-cecal. Para indução da septicemia o ceco dos animais foi perfurado (2 vezes) com agulha $23 \mathrm{G}$, seguido de leve compressão para assegurar a saída de conteúdo intestinal. Após a perfuração do ceco, o intestino foi recolocado na cavidade abdominal e a musculatura e a pele suturadas. Após a sutura, os animais foram mantidos em ambiente aquecido até a recuperação da anestesia (60 a 120 minutos). No modelo de IRI, o tratamento com AGCCs foi realizado na dose de $200 \mathrm{mg} / \mathrm{kg}$ de animal tanto por $1 \mathrm{X}$, sendo esta administrada 30 minutos antes da indução da isquemia ou por 2x, sendo uma 30 minutos antes da isquemia e a outra no momento da reperfusão. Em um grupo específico de animais, foi realizado o mesmo protocolo de tratamento com os AGCC, mas os animais não foram submetidos à cirurgia, a fim de verificar se somente o tratamento com os AGCC afetaria algum parâmetro na função renal e/ou na inflamação. As análises posteriores in vivo neste modelo foram realizadas somente nos animais tratados com acetato, por conta da observação de maior proteção com este tratamento. Já no modelo de sepse, realizamos dois tratamentos com acetato. O primeiro foi na dose de $200 \mathrm{mg} / \mathrm{kg} 1$ e $6 \mathrm{~h}$ após a cirurgia. No segundo tratamento, os animais foram tratados com $400 \mathrm{mg} / \mathrm{kg}$ de acetato um dia antes, no 
momento e após seis horas da cirurgia. A eutanásia dos animais foi realizada com quetamina e xilazina, $24 \mathrm{~h}$ após as cirurgias, e foi realizada a coleta do material (sangue e rim).

3.3 Avaliação histológica do tecido renal

O material foi fixado em formol a 10\% tamponado, até a montagem em blocos de parafina. Após processamento habitual, foi estudado pelo menos um corte de cada fragmento, na coloração de hematoxilina-eosina. O estudo histomorfométrico avaliou a presença e quantificação de necrose tubular (NT) na medula externa (ME) na coloração hematoxilina-eosina. Utilizou-se o programa KS30o (Zeiss) e um microscópio de luz comum. Após a digitalização da imagem dos campos, foi feita a seleção das áreas com características de necrose ou regeneração tubular, que eram então contabilizadas pelo programa. Os resultados foram expressos em percentagem de área acometida em relação à área total do campo avaliado (145.846,7 $\mu \mathrm{m} 2)$. Foram avaliados 25 campos de aumento de 835X por lâmina, escolhidos aleatoriamente, que praticamente cobriram toda a medular externa dos cortes. Com este número de campos avaliou-se uma área de 3.646.167,5 um² ou 3,65 mm² em cada animal por lâmina. A análise foi feita sem que o observador tenha acesso à identificação de qual grupo pertencia o material analisado. Os resultados encontrados foram validados na totalidade dos casos por análise quantitativa feita por patologista, também sem identificação dos casos. Foram consideradas alterações compatíveis com necrose tubular: perda da borda em escova, perda da integridade citoplasmática e nuclear, perda de células tubulares individuais, presença de cilindros hialinos preenchendo a luz tubular em substituição às células tubulares perdidas.

3.4 Cultivo e administração dos probióticos Bifidobacterium longumm e Bifidobacteruim adolescentis

A espécie de bifidobactéria (Bifidobacterium longum) utilizada no estudo, gentilmente cultivado e cedido pela Dra. Caroline Marcantônio Ferreira, do Departamento de Farmacologia, do ICB/USP), foi isolada e caracterizada no Laboratório de Ecologia e Fisiologia de Microorganismos do Instituto de Ciências Biológicas da Universidade Federal de Minas Gerais. A Bifidobacteria longum foi isolada a partir das fezes de uma criança de 5 anos saudável, da cidade de Salvador, Bahia, e identificada através de testes morfológicos, colorimétricos, respiratórios e bioquímicos seguido por análise de PCR multiplex, conforme Kwon et al. (84). Já a Bifidobacterium adolescentis foi adquirida da ATCC (Manassas, VA, USA). As bactérias foram replicadas em meio MRS broth (Difco, Detroit, MI, USA) e colocadas em condições de crescimento anaeróbico através do uso de uma jarra anaeróbica a 
$37^{\circ} \mathrm{C}$ sem agitação por $48 \mathrm{~h}$. A administração dos probióticos foi realizada por gavagem, com um inóculo de aproximadamente $10^{8}$ de bactéria diariamente, durante 10 dias até o dia do sacrifício. Amostras de plasma e fezes foram coletadas antes e após o tratamento, mas antes da cirurgia para dosagem de acetato e dos níveis de ureia e creatinina.

3.5 Geração/maturação de células dendríticas derivadas da medula óssea (BM-DC)

As células dendríticas foram geradas a partir de células da medula óssea (BM-DC) na presença de GM-CSF (20 ng/mL, da R\&D, R\&D Systems ${ }^{\circledR}$, Minneapolis, MN, USA) por 7 dias em meio IMDM suplementado com 10\% de soro bovino fetal. BM-DC foram estimuladas com LPS (20 ng/mL) (Sigma, Sigma-Aldrich, St.Louis, MO, USA) na presença e/ou ausência de acetato $(25 \mathrm{mM})$, propionato $(12 \mathrm{mM})$ e butirato $(3,2 \mathrm{mM})$ todos da Sigma, diluídos em PBS, com pH ajustado em 7,4 com hidróxido de sódio ( $\mathrm{NaOH}$ a 10 e 1 N). Após, as células foram coletadas e marcadas com anticorpos específicos congugados com fluorocromo para as moléculas CD8o CD86 e CD40 e a aquisição dos dados foi realizada por citometria de fluxo no aparelho FACS Canto II (BD Bioscence, San Jose, CA, USA)

3.5.1 Co-cultivo de células pré-tratadas com AGCC e esplenócitos de camundongos Balb/c para análise da proliferação frente a um estímulo alo-específico

Esplenócitos de animais RAG KO de C57BL/6 (APC como doador) foram pré-tratados com AGCC por 24 h. Após lavagem, estas células foram co-cultivadas com esplenócitos de animais Balb/c marcados com CFSE, do inglês Carboxyfluorescein succinimidyl Ester, (Sigma) por 4 dias na proporção de 1:3, respectivamente ( $2 \times 10^{5}$ células/ poço no total) em placa de fundo "U" de 96 poços. O CFSE foi utilizado na concentração final de $5 \mu \mathrm{M}$, diluído em PBS pré-aquecido por 10 minutos a $37{ }^{\circ} \mathrm{C}$. A densidade de células para realização da marcação foi de $1 \times 10^{7}$ células/mL. Ao final de 4 dias, células foram marcadas com anticorpos específicos conjugados com fluorocromo para CD4-PE e CD8-APC e a avaliação da proliferação foi realizada usando FACS Canto II (BD Bioscience).

\subsubsection{Ativação de esplenócitos frente a estímulso policlonais e específicos}

Esplenócitos de camundongos C57BL/6 OTII (5x105) marcados com CFSE (Sigma) foram estimulados com anti-CD3 e anti-CD28 (estímulo policlonal) ou com peptídeo Ovalbumina ( $2 \mu \mathrm{g} / \mathrm{mL}$, Proteimax, Cotia,SP, Brasil) como estímulo específico na presença de acetato $(25 \mathrm{mM})$, propionato $(12 \mathrm{mM})$ e butirato $(3,2 \mathrm{mM})$ por 4 dias. A avaliação da proliferação foi realizada por citometria de fluxo no aparelho FACS Canto II (BD Bioscence) 
3.6 Dosagens dos Ácidos graxos de Cadeia Curta

Para a dosagem dos AGCCS foram utilizados os seguintes reagentes: ácidos acético, butírico, propiônico e cítrico, todos adquiridos da Sigma, butanol da Carlo Erba (Cornaredo, Milão, Itália), acetonitrila da Merck (Darmstadt, Alemanha) e Tetrahidrofurano da Acros Organics (Fair Lawn, NJ, USA). As dosagens foram realizadas pela professora Dra Claudete Valduga e seu aluno Willian Ribeiro do departamento de farmácia e biotecnologia da Universidade Anhanguera de São Paulo.

\subsubsection{Cromatografia}

As análises cromatográficas foram realizadas usando um detector de ionização em chama (FID, Flame ionization detector) de injeção líquida automática, equipado com uma coluna capilar de sílica. A temperatura inicial de $100{ }^{\circ} \mathrm{C}$ (mantida por 7 minutos) foi elevada a $200{ }^{\circ} \mathrm{C}$ a uma taxa de $25{ }^{\circ} \mathrm{C} /$ min e mantida por 5 minutos. A temperatura do FID foi mantida a $260{ }^{\circ} \mathrm{C}$. As amostras $(5 \mu \mathrm{L})$ foram injetadas a $250{ }^{\circ} \mathrm{C}$ e o nitrogênio foi utilizado como gás carreador e as amostras foram dosadas em triplicata.

\subsubsection{Preparação do padrão e da curva de calibração}

Acetato, propionato e o butirato foram diluídos na concentração de $1,0 \mathrm{mg} / \mathrm{mL}$ em solução com bunatol, tetrahidrofurano e acetonitrila na proporção de (5:3:2, respectivamente). Após a diluição, foram realizadas outras para obtenção de solução padrão em diferentes concentrações. A curva padrão foi preparada com plasma humano livre de AGCCs e foram adicionados os AGCCs na concentração de $1 \mathrm{mg} / \mathrm{mL}$. Após, foi realizada diluições seriadas em uma faixa de $0,015^{-1} \mathrm{mg} / \mathrm{mL}$ seguida de homogeneização por $1 \mathrm{~min}$ e centrifugação a 10,000 rpm por 10 minutos. O sobrenadante foi transferido para microtubos e $5 \mu \mathrm{L}$ foram injetados em triplicata na cromatografia gasosa. Para a quantificação dos AGCCs, uma curva de calibração na mesma faixa de concentração anterior foi construída. 


\subsubsection{Preparação da amostra}

As amostras de plasma foram processadas conforme procedimento anterior, exceto para o volume de amostra utilizado, que foi de $100 \mu \mathrm{L}$ e todos os outros componentes foram reduzidos a metade. A concentração está expressa em mM. Já as amostras de fezes foram pesadas e homogeneizadas em $100 \mathrm{~mL}$ água destilada. Subsequentemente, $40 \mathrm{mg}$ de cloreto de sódio, $20 \mathrm{mg}$ de ácido cítrico, $40 \mu \mathrm{L}$ de ácido hidroclórico a 0,1 M e $200 \mu \mathrm{L}$ de butanol: tetrahidrofurano: acetonitrilo $(5: 3: 2)$ foram adicionados. Os tubos foram homogeneizados por 1 minuto e centrifugado a $10.000 \mathrm{rpm}$ por 10 minutos. O sobrenadante foi transferido para um microtubo de $1,5 \mathrm{~mL}$ e $5 \mu \mathrm{L}$ foram injetados em triplicata

3.7 Cultura de linhagem de célula epitelial renal e modelo de lesão celular

Células epiteliais renais camundongos (MM55.k) foram semeadas em meio DMEMhigh com 10\% soro fetal bovino em placas de 6 poços de fundo chato e estimuladas com uma mistura de estímulos a fim de mimetizar a ocorrência do processo inflamatório in vivo (LPS: $10 \mu \mathrm{g} / \mathrm{mL}$ (Sigma); Zymosan: $10 \mu \mathrm{g} / \mathrm{mL}$ (Sigma); e as seguintes citocinas recombinantes rIL6:50 ng/mL; rIL-1 $\beta$ : $50 \mathrm{ng} / \mathrm{mL}$ and rTNF- $\alpha$ : $100 \mathrm{ng} / \mathrm{mL}$, todas da R\&D , na presença e/ou ausência de acetato $25 \mathrm{mM}$, propionato $12 \mathrm{mM}$ e butirato 3,2 $\mathrm{mM}$ por 24h. Após foi avaliada a fosforilação de NF-kB por citometria de fluxo utilizadno o aparelho FACS Canto (BD Bioscience).

3.8 Modelo de hipóxia em linhagem de células tubulares renais

Células HK-2 ou MM55.k, obtidas pela American Type Culture Collection (ATCC), entre a passagem 10 e 20, foram cultivadas em meio DMEM-High glucose com $10 \%$ soro bovino fetal, semeadas sobre lâminas de vidro (para microscopia confocal) ou plaqueadas em placas de 6 poços de fundo chato e submetidas a hipóxia (1\% O2; 5\% CO2; N2 balanceado) em incubadora (Ruskinn Technology, Bridgend, UK) durante 24 horas ou deixadas em normóxia, tratadas ou não com AGCC desde o início da hipóxia. Após 30 e 10 minutos antes das $24 \mathrm{~h}$ de hypoxia, células foram tratadas com hipoxiprobe (50 $\mu \mathrm{M})$ e mitosox $(5 \mu \mathrm{M})$, respectivamente. As células foram fixadas com formaldeído, bloqueadas com PBS contendo $0.15 \%$ gelatina, $0.1 \% \mathrm{NaN}_{3}$ e permeabilizadas com PGN+ saponina. As células então foram incubadas com Anticorpo primário para HIF-1a (Abcam, abcam $囚$, Cambridge, MA, USA) overnight a $4{ }^{\circ} \mathrm{C}$ seguido por incubação com anticorpo secundário anti-humano conjugado com FITC e realizado microscopia eletrônica. 
3.9 Extração do RNA, Transcrição Reversa, Real-time PCR e PCRarray

Os tecidos coletados foram imediatamente imergidos em nitrogênio liquido e armazenados a $-80{ }^{\circ} \mathrm{C}$. O RNA total foi extraído pelo método do Trizol@ (Invitrogen, Carlsbad, CA, USA) e quantificação foi realizada no NanoDrop® ND10oo (Thermo Scientific, Rockford, IL, USA). O DNA complementar (cDNA) foi reversamente transcrito com $2 \mu \mathrm{g}$ de RNA total utilizando a enzima Moloney Murine Leukemia Virus Reverse Transcriptase MMLV (Promega, Madison, WI, USA) e primer oligo-dT. Taqman Real time PCR foi empregado, utilizando primers e sondas comercialmente disponíveis (Life Technologies) para os seguintes genes: IL-6 (Mmo0446190_m1); KC (Mm04207460_m1); CD68 (Mmo3047340_m1); MCP-1 (Mmoo441242_m1); TNFa (Mmo0443258_m1); BCL-2 (Mmoo477631_m1), VEGF (Mmo1281449_m1); TLR4 (Mmo0445273_m1); TLR2 (Mmo1213946_g1); MYD88 (Mmoo440338_m1); HSP70 (Mm; HMGB1 (Mmo0849805_gh); Biglicano (Mmo1191753m1), todos da Life Technologies ${ }^{\mathrm{TM}}$, Carlsbad, CA, USA). A actina-beta foi utilizada como gene controle (Invitrogen). A detecção dos genes foi realizada no aparelho ABI Prism 7300 (Life Technologies). Os genes GPR41 (Ffar3) e GPR43 (Ffar2) tiveram suas detecções realizadas com SybrGreenß (Life Technologies) com os seguintes sequências de pares de primers: GPR41S 5'TGCCTTGGACTCAGCAAGTCA3' and GPR41AS 5'CCTGCGGTCCACTCTTTTCTCT'; GPR43S 5'TTTGTACATG TGCTCCGCTGAT3' e GPR43AS 5'CCAGTGACTGGTGACACAGAGG3' e HPRT (gene controle) HPRTS 5'CTGATGGACTGATTATGGACAGGAC3';HPRTAS5'GCAGGTCAGGAAAGAACTTATAGCC3'. O nível de expressão relativa foi calculado através do método $2^{-\Delta \Delta C t}$, e o grupo controle foi utilizado como grupo referência. Um total de 96 genes que codificam para enzimas associadas com modificação da cromatina (PAMM-085) foram medidas utilizando PCRarray da SABiosciences (Qiagen, Venlo, Netherlands). A detecção foi realizada no ABI730o (Life Technologies) e as analises foram realizadas online no site disponível pela SABioscence.

3.10 Avaliação da função renal pelos níveis de ureia e creatinina

Creatinina sérica foi medida através do método de Jaffé's e a ureia sérica foi mensurada usando o kit ureia (Labtest, Minas Gerais, Brasil). 
3.11 Dosagem de glutationa reduzida e oxidada

A medida da glutationa reduzida (GSH) e da glutationa oxidada (GSSG) no realizada no extrato do tecido renal utilizando o kit Glutatione (GSH/GSSG/Total) Fluorometric Assay, (BioVision, Milpita, CA, USA) seguindo as instruções do fabricante.

\subsection{Bioplex}

O tecido renal lisado em tampão RIPA ou o soro dos animais submetidos à indução de doença foram utilizados para realização do BioPlex mice Plex cytokine assay kit (BioRad Laboratories Inc., Hercules, CA, USA) para a detecção de citocinas e quimiocinas simultaneamente. A leitura do ensaio foi realizada no BioPlex suspension array syste e os dados foram analisados usando software BioPlex Manager version 4.o. As curvas-padrão abrangeram a detecção entre 32.000 a $1.95 \mathrm{pg} / \mathrm{mL}$.

\subsection{Avaliação da apoptose}

A avaliação da apoptose foi realizada através da técnica de TUNEL, usando o Cell Death Detection Kit TMR Red (Roche Diagnostics GmbH, Mannheim, Germany).

\subsection{Imunohistoquímica}

Fragmentos renais de todos os grupos experimentais foram fixados em solução formaldeído tamponado $4 \%(\mathrm{pH}=7,0)$, emblocados em parafina e submetidos a banhos seriados de xilol e álcool. Cortes histológicos foram realizados e as amostras foram desparafinizadas, rehidratadas e submetidas a tampão citrato a temperatura de $96{ }^{\circ} \mathrm{C}$ para recuperação antigênica. A atividade de peroxidase endógeno foi bloqueada com peróxido de hidrogênio (3\%) e solução de bloqueio de proteína (Dako, Glostrup, Denmark) foi adicionada. Anticorpos primários (diluição 1:100) para PCNA, MPO ou controle negativo foram incubados em câmara escura umidificada a $4{ }^{\circ} \mathrm{C}$ overnight, seguido por uma incubação com um polímero marcado (Dual Link System-HRP, DAKO), usando duas incubações de 30 minutos a temperatura ambiente. A marcação com substrato cromógeno 3,3-0diaminobenzidina (DAB) foi realizada por incubação de 1-3 minutos a temperatura ambiente (cor marrom) seguida por uma contracoloração com hematoxilina. A análise da marcação positiva para estas moléculas foi realizada de ao menos 20 fotos por rim usando o programa de análise de imagens image $\mathrm{J}$ (KS300, Zeis system). 
3.15 Citometria de fluxo

Para análise dos leucócitos infiltrantes no rim, os órgãos foram coletados, cortados em pedaços menores e colocados em $3 \mathrm{~mL}$ de PBS contendo DNAse $(1 \mathrm{mg} / \mathrm{mL})$ e Colagenase tipo IV $(2 \mathrm{mg} / \mathrm{mL})$ por $1 \mathrm{~h}$ a $37{ }^{\circ} \mathrm{C}$. Posteriormente, essa digestão foi peneirada (70-100 $\left.\mu \mathrm{m}\right)$ e separada por gradiente Percoll. O anel de células foi coletado, centrifugado e ressuspendido em $20 \mathrm{~mL}$ de tampão FACS. As marcações com anticorpos monoclonais foram realizadas para as seguintes moléculas de superfície: anti-CD11b APC, anti-F4/80 PERCP, anti-CD11c Pacific Blue e anti-CD40 PE (BD Biosciences, San Jose, CA, USA). A aquisição das amostras foi realizada no aparelho FACS Canto II usando o software FACSDIVA (ambos BD Biosciences) e então analisadas utilizando o programa FlowJo (Tree Star, San Carlo, CA). O nível da fluorescência basal foi determinado utilizando células não marcadas e a compensação foi realizada usando células marcadas individualmente com cada fluorocromo (APC, PE, PercP e Pacific Blue). Foram analisados 50.0oo eventos.

\subsubsection{Análise das células dendríticas derivadas da medula óssea}

As células foram coletadas e centrifugadas por 5 minutos a $1,500 \mathrm{rpm}$ a $4{ }^{\circ} \mathrm{C}$. Após desprezar o sobrenandate, anticorpos conjugados com fluorocromos foram para as moléculas CD11c-pacific blue; CD80-PercP; CD86-APC e CD40-PE foram adicionados na diluição de 1;100 em volume de $20 \mu \mathrm{L}$ e incubados por 30 minutos em tampão FACS (PBS, 2\% soro bovino fetal e $0,02 \%$ de ázida sódica) a $4{ }^{\circ} \mathrm{C}$. Após, as amostras foram lavados com tampão FACS, centrifugadas mais uma vez por 5 minutos a $1,500 \mathrm{rpm}$ a $4{ }^{\circ} \mathrm{C}$ e ressuspendidas com $200 \mu \mathrm{L}$ de Tampão FACS. A leitura foi realizada no FACS Canto II (BD Bioscience)

\subsubsection{Análise da fosforilação de NF-kB em linhagem de célula tubular renal}

Para a detecção da ativação de NF- $\mathrm{B}$, foi utilizado kit de permeabilização usado na detecção do fator de transcrição foxp3 (Ebioscence, Ebioscience, San Diego, CA, USA), seguindo as recomendações do fabricante. Anticorpo específico para a região fosforilada (Ser536) da subunidade p65 do complexo foi adquirido, conjugado com o fluorocromo APC (Cell signalling Technology®, Danvers, MA, USA, \#4887, diluição 1:50). 
3.16 Produção de óxido nítrico

Para a produção de Oxido Nítrico (Nitric Oxide, NO), uma medida indireta (DAF, diaminofluoresceína diacetato) foi realizada e a leitura foi realizada por citometria de fluxo no aparelho FACS Canto II no canal FL1.

\subsection{Western Blot}

Extrato renal foi obtido através da lise com tampão RIPA contendo inibidores de protease e fosfatase (Roche, Indianapolis, IN, USA). A quantificação da proteína foi realizada com BCA Protein Assay Reagent (Thermo Scientific). Um total de $50 \mu \mathrm{g}$ de proteína por amostra foi utilizado em um gel de SDS-PAGE e transferido para uma membrana de nitrocelulose (Millipore, Billerica, MA, USA). Anticorpos primários foram empregados para detecção das moléculas IKBa (diluição 1:1000, Cell Signaling) e ATG-7 (diluição 1:100o, abcam) e $\beta$-actina (diluição 1:1000, Sigma).

3.18 Microscopia confocal e medida de lactato

Imagens confocais foram obtidas usando o aparelho Zeiss LSM 780 (Carl Zeiss, Jena, Germany) no Centro de facilidades e apoio a pesquisa (CEFAP/USP). As imagens foram adquiridas com uma objetiva de 63x (1.4NA) utilizando o programa Zen (Carl Zeiss). A dosagem do lactato no sobrenadante de cultura foi realizada usando kit comercialmente disponível (Labtest), seguindo as instruções do fabricante.

3.19 Detecção da Mieloperoxidase (MPO) no tecido renal

A dosagem no tecido renal foi estimada como descrito por Hillegass et al., 1990 (85). A leitura foi realizada no espectofotômetro a um comprimento de onda de $460 \mathrm{~nm}$.

3.20 Ensaio da atividade de histone deacetilase (HDAC)

A dosagem da atividade da histone deacetilase no tecido renal foi realizada com um total de $70 \mu \mathrm{g}$ de proteína utilizando o HDAC activity colorimetric assay kit (K-331-100), seguindo as instruções do fabricante (Biovision, Biovision Inc., Milpitas, CA, USA). Os dados são expressos como média da concentração em $\mu \mathrm{M}$ de lisina deacetil. 
3.21 Avaliação do status global de metilação do DNA nas amostras de tecido renal e do conteúdo de DNA mitocondrial

O DNA foi obtido a partir da extração do tecido renal com o kit DNeasy® Blood and Tissue Kit (Qiagen) e quantificado no NanoDrop® ND10oo. A metilação do DNA no tecido renal foi avaliada através do protocolo adaptado de Sharma et al., 2011 (86). O DNA extraído (400 ng) foi digerido ou com Hpa I, ou Msp II (New England, New England Biolabs Inc, Ipswich, MA, USA) overnight a $37{ }^{\circ} \mathrm{C}$ com posterior incubação a $80{ }^{\circ} \mathrm{C}$ para inativação das enzimas. Essas enzimas de restrição reconhecem a mesma sequência no DNA, que é 5' CCGG 3' e ambas são capazes de clivar a sequência quando não está metilada. Entretanto, quando a citosina interna da sequência está metilada, somente a enzima Msp I é capaz de clivar a sequência. Após a digestão o produto digerido foi submetido à eletroforese em gel de agarose (1\%) e a imagem do gel foi adquirida no aparelho Gbox (Syngene, Synoptics Ltd, Cambridge, England). Foi realizada a quantificada de cada banda originada da digestão ou não com a enzima. A metilação global do DNA foi obtida a partir da fórmula: \% metilação $=[(\mathrm{H}-$ M)/G] ${ }^{*}$ 100, no qual H é a densidade da banda digerida com Hpa II, M é a densidade da banda digerida com Msp I e G é a densidade da banda do DNA genômico (sem digestão). O conteúdo de DNA mitocondrial (mtDNA) no rim foi avaliada por PCR em tempo real com primers específicos desenhados para o gene presente no mtDNA: sense 5'CCCAATCTCTACCAGCATC-3' e antisense 5'-GGCTCATAGTATAGCTGGAG-3'. A normalização foi realizada a partir da amplificação de um gene presente no DNA genômico da célula (gDNA) utilizando os seguintes primers: sense 5'-GTACCCACCTGTCGTCC-3', e antisense 5'-GTCCACGAGACCAATGACTG-3'. Os dados são apresentados como a razão entre mtDNA pelo gDNA.

3.22 Análise estatística

Os dados são apresentados com média e desvio padrão. Para comparação entre dois grupos foi empregado teste - $T$ de student enquanto nas análises de comparação entre três ou mais grupos foi empregado o teste de ANOVA com correção de Bonferroni. A curva de sobrevida foi avaliada utilizando o teste de Kaplan-Meier. O valor de $\mathrm{p}<0,05$ foi considerado significante. Todos os gráficos e análises estatísticas foram realizados utilizando o programa Graph-Pad PRISM (GraphPad Software Inc., LaJolla, CA, USA). 
4 RESULTADOS 
4.1 Tratamento dos animais com AGCC na IRI

Até o momento, não havia na literatura protocolos de tratamento com os AGCC em modelo de IRI. Apenas um trabalho no qual foram administrados ácidos graxos nitrados, que são derivados do ácido linoleico e neste modelo e foi realizado por via intraperitoneal (87). Outros estudos dos AGCCs também foram realizados em modelo de colite $(57,81)$ e sepse $(88,89)$, sendo a administração neste último, também por via intraperitoneal. Diante disso, resolvemos iniciar nossos estudos tratando os camundongos por via intraperitoneal. Inicialmente, tratamos os camundongos com $200 \mathrm{mg} / \mathrm{kg}$ de cada AGCC. A escolha da dose foi realizada a partir de um único estudo realizado com butirato em modelo de sepse $(13,88)$. O esquema de tratamento está ilustrado na figura 1.

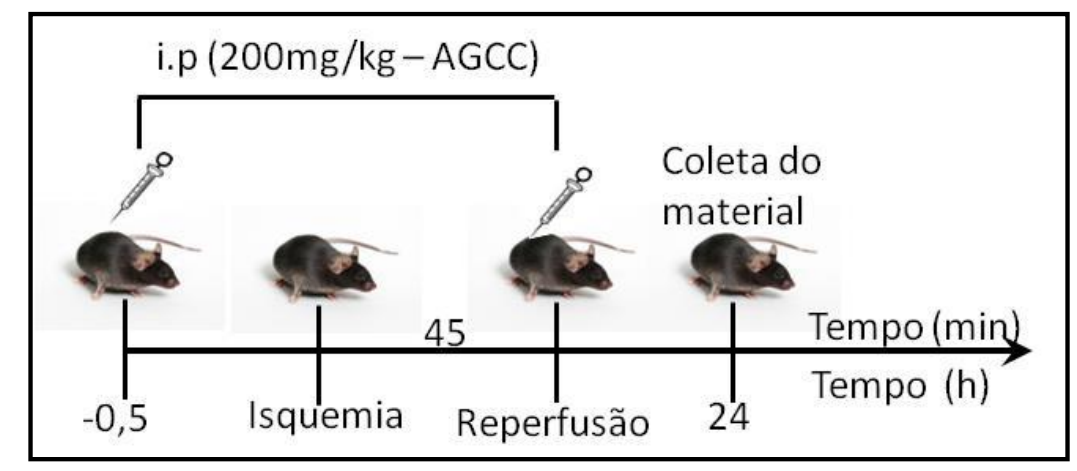

Figura 1. Esquema de tratamento dos camundongos no modelo de lesão de isquemia e reperfusão (IRI) renal bilateral. Camundongos $\mathrm{C} 57 \mathrm{BL} / 6(\mathrm{n}=5$ por grupo) foram submetidos a isquemia por 45 minutos e após esse período foram submetidos a $24 \mathrm{~h}$ de reperfusão. Ao fim das $24 \mathrm{~h}$ foi realizada a coleta do material. O tratamento com o pool (200 mg/kg de cada AGCC) dos três ou separadamente, foi realizado na dose de $200 \mathrm{mg} / \mathrm{kg}$ de animal por $2 \mathrm{X}$, sendo uma dose $0,5 \mathrm{~h}$ antes da isquemia e a outra dose no momento da reperfusão.

Observamos que o tratamento com o pool dos três AGCC juntos na dose de 200 $\mathrm{mg} / \mathrm{kg}$ cada um administrado somente $1 \mathrm{x}$ antes da isquemia não protegeu os camundongos da lesão renal, pois os níveis de uréia e creatinina séricas foram semelhantes ao grupo IRI não tratado. Entretanto, o tratamento com o pool dos AGCC em duas doses diminuiu os níveis de creatinina e uréia séricas (Figura 2A). 

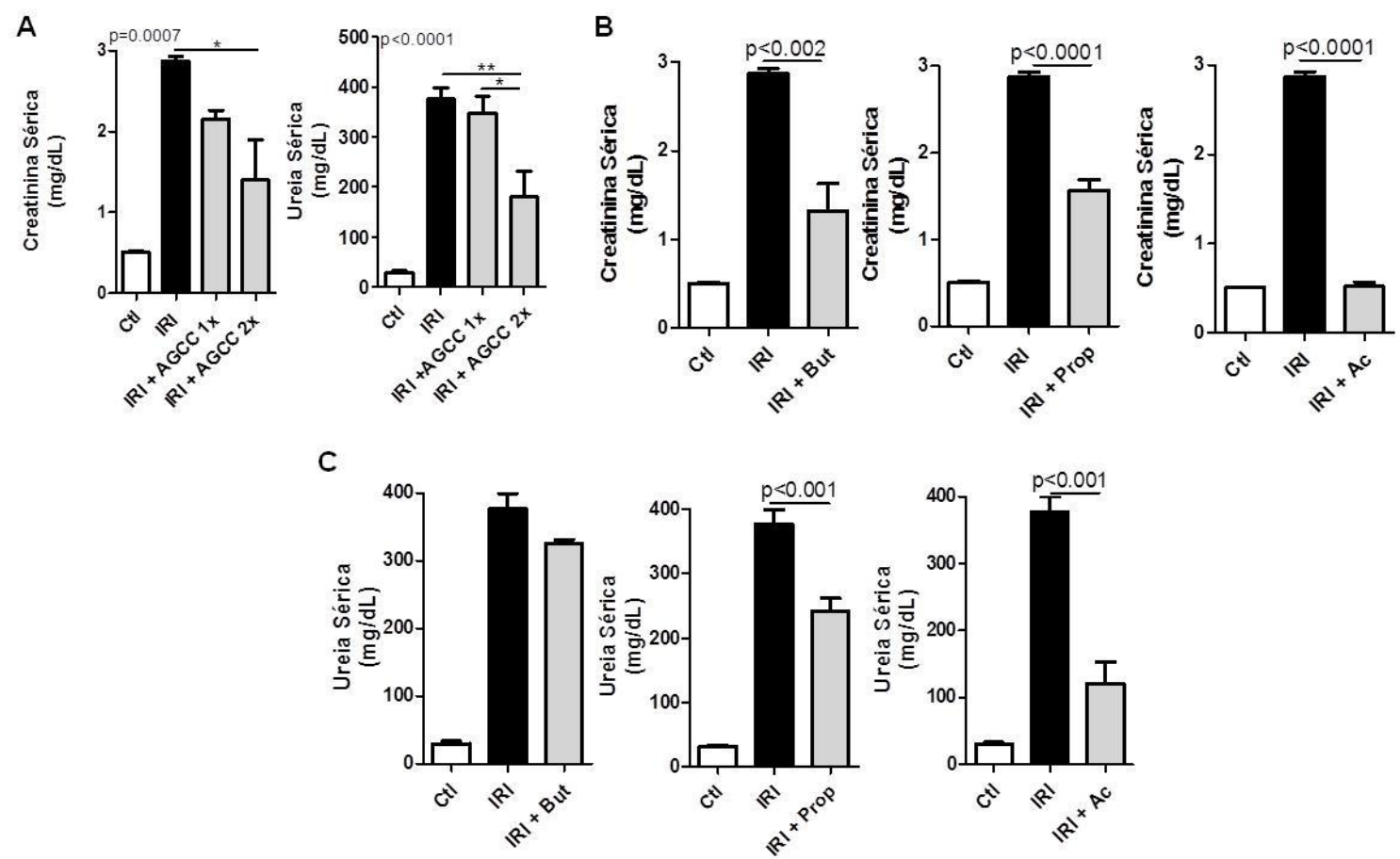

Figura 2. Função renal dos camundongos submetidos à IRI renal e tratados com os AGCC. Camundongos foram tratado com pool dos Ácidos Graxos de Cadeia Curta (AGCC) por 1 ou $2 \mathrm{X}$ ou com os AGCC separadamente por 2X. (A) níveis de creatinina e ureia sérica no soro de camundongos submetidos à IRI bilateral tratados ou não com AGCC por 1 ou $2 X$. (B-C) níveis de creatinina (B) e ureia (C) séricas no soro de camundongos submetidos à IRI bilateral e tratados ou não com acetato, butirato ou propionato, individualmente por 2 X. Dose do tratamento: $200 \mathrm{mg} / \mathrm{kg}$ de animal. Teste $t$ de student em B. ${ }^{*}=\mathrm{p}<0,05 ;{ }^{* *} \mathrm{p}<0,01 . \mathrm{n}=5$ por grupo. Ctl: controle; IRI: ischemia reperfusion injury; Ac: acetato; Prop: propionato; But: butirato.

Após a verificação de que o pool de AGCC administrados 2x protegeu os camundongos da IRI, nós avaliamos se os AGCC administrados individualmente também protegeriam da lesão. Como mostrado na figura 2B, após a administração da dose de $200 \mathrm{mg} / \mathrm{kg}$ (2x) individual de acetato, butirato e propionato, foi possível observar uma redução nos níveis de creatinina sérica para todos os tratamentos. Já nos níveis de ureia, apenas no tratamento com butirato não foi observada redução (figura $2 \mathrm{C}$ ). Importante ressaltar que os AGCC não foram tóxicos para os animais, ao menos nessa dose, pois o tratamento com os AGCC em animais não submetidos à IRI renal não alterou os níveis de creatinina e ureia séricas tampouco níveis de expressão de mRNA e de proteínas de moléculas relacionadas com o processo inflamatório (Figura 3A-D). 
A
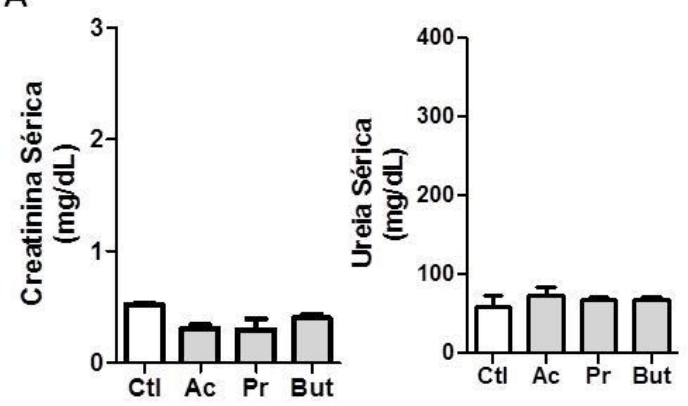

B
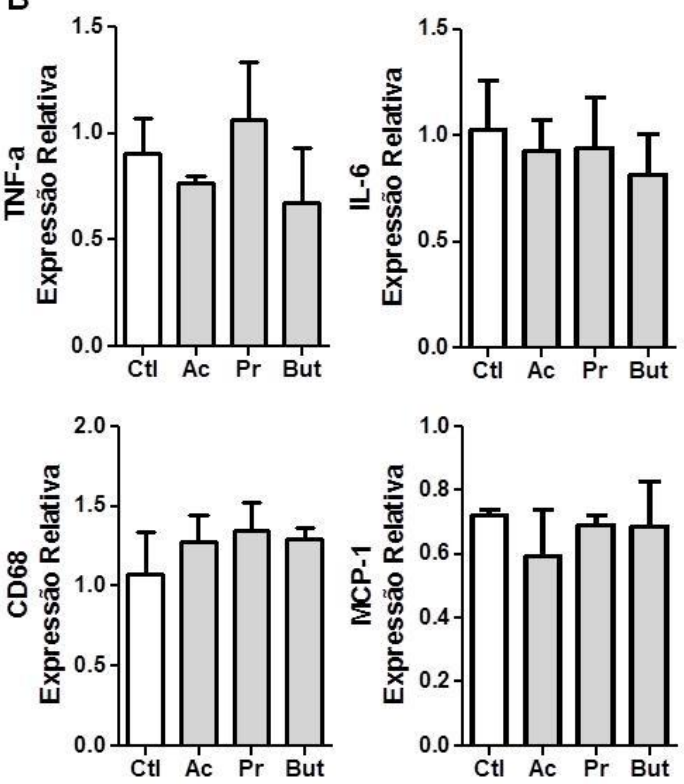

C
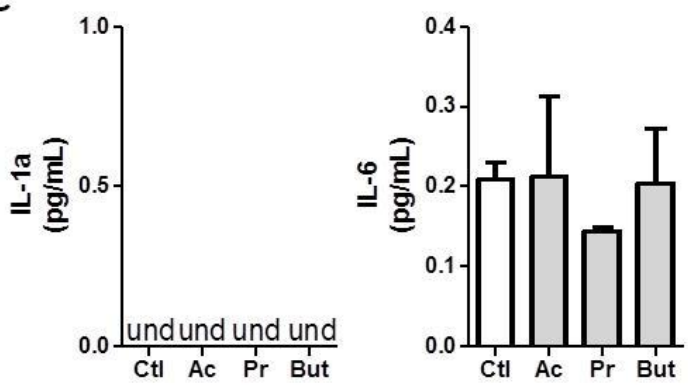

D
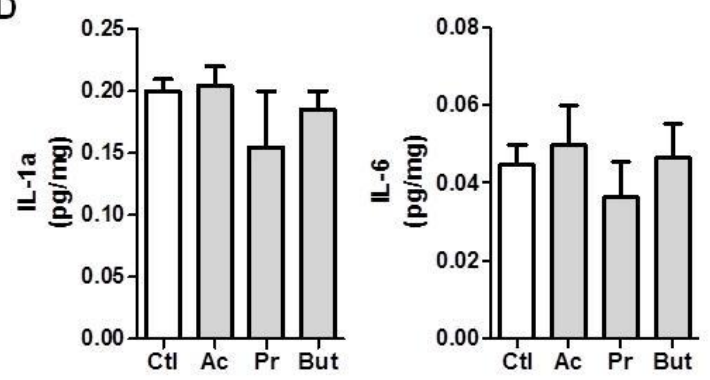

Figura 3. Função renal e de parâmetros inflamatórios nos camundongos tratados com os AGCC sem IRI renal. Camundongos foram tratados com os Ácidos Graxos de Cadeia Curta(AGCC) por 2X, em mesma dose, mas sem submetê-los à IRI renal e função renal e parâmetros inflamatórios foram avaliados. (A) níveis de creatinina e ureia sérica no soro de camundongos. (B,D) expressão gênica (B) e expressão proteica (D) no rim. (C) níveis de citocinas no soro dos animais. AGCC 2X: Camundongos tratados com AGCC 30 minutos antes da isquemia e no momento da reperfusão. Os dados são expressos como média \pm desvio padrão. Teste ANOVA em A com correção pós-teste. Ctl: controle; IRI: ischemia reperfusion injury; Ac: acetato; Prop: propionato; But: butirato.

Considerando os dois parâmetros, a administração do acetato foi a que mais protegeu os animais da lesão. Tendo observado a melhor função renal após o tratamento com o acetato, através dos níveis de creatinina, nós avaliamos outros parâmetros somente neste grupo de animais.

4.2 Avaliação, da necrose tecidual, do estado inflamatório local e sistêmico e do estresse oxidativo nos camundongos submetidos à IRI renal e tratados com acetato

É sabido que neste tipo de lesão ocorre um aumento da necrose tecidual, dos níveis de citocinas inflamatórias e quimiocinas local e sistemicamente, sendo estes últimos os 
mecanismos proclamados como participantes no processo de lesão em outros órgãos $(26,27)$. Análises histológicas realizadas por patologista, sem o prévio conhecimento da identificação das amostras, mostraram um aumento da necrose tecidual no grupo submetido à IRI e, no grupo tratado com acetato uma diminuição da necrose tecidual (Figura 4A).

$\mathrm{Na}$ avaliação da produção de citocinas inflamatórias e quimiocinas, verificamos que o tratamento com acetato diminui os níveis protéicos das citocinas IL-1 $\beta$, IL-6, TNF- $\alpha$ e da quimiocina MCP-1 no rim (Figura 4B), além de diminuir os níveis protéicos das citocinas IL6, IL-1a, e das quimiocinas RANTES e MCP-1 no soro (Figura 4C).
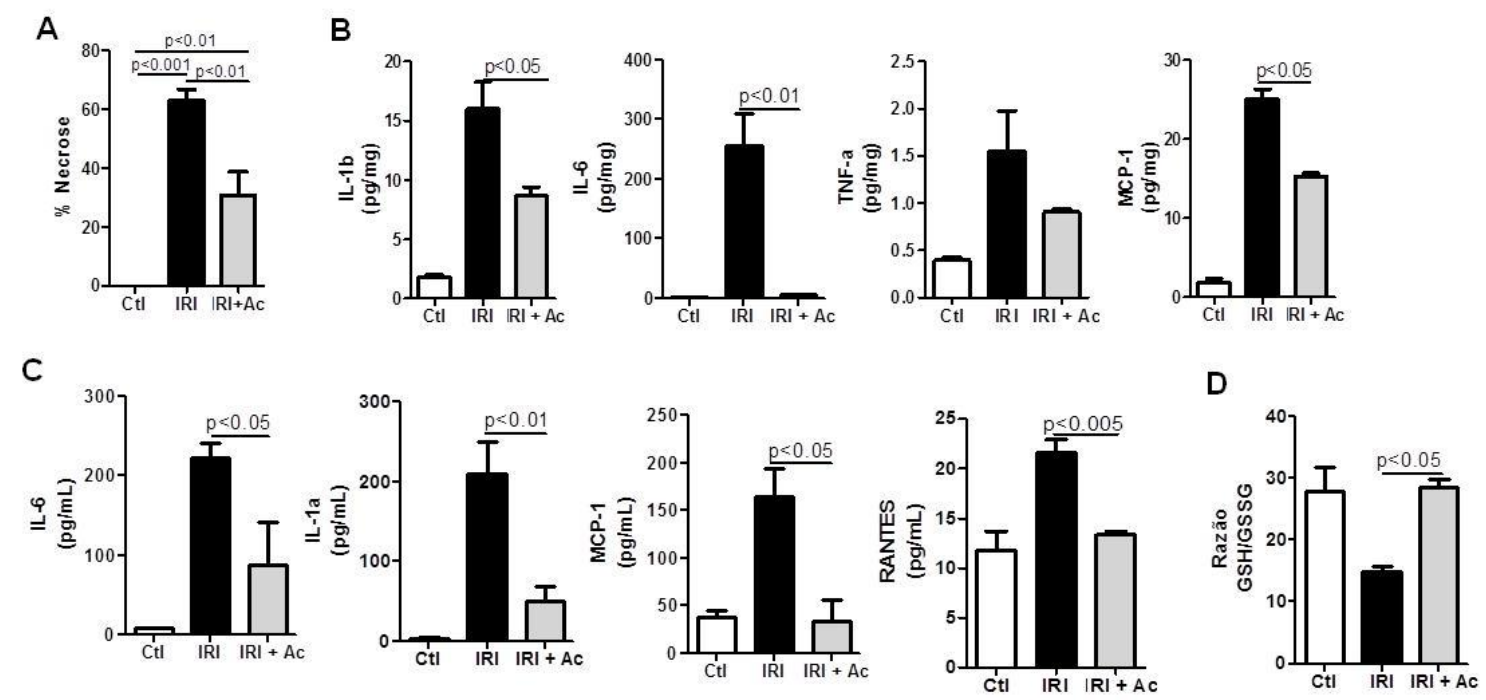

Figura 4. Necrose tecidual, níveis de citocinas, quimiocinas e do estresse oxidativo na IRI após o tratamento com o acetato. (A) Análise da porcentagem de necrose no tecido renal avaliado em cortes com hematoxilina e eosina. Análise realizada às cegas por patologista. Foram avaliados 10 campos por rim. (B-C) Os níveis de citocinas pro-inflamatórias e de quimiocinas foram detectados no lisado do tecido renal (B) e no soro (C) de camundongos submetidos à IRI renal, tratados ou não com acetato. (D) Razão da medida da glutationa reduzida (GSH) e da glutationa oxidada (GSSG) no tecido renal. Teste $t$ student $. \mathrm{n}=5$ por grupo. $\mathrm{IRI}=$ isquemia reperfusão injury. $\mathrm{Ac}=$ acetato.

O estresse oxidativo foi avaliado pela dosagem da glutationa reduzida (GSH) e oxidada (GSSG). Na presença de estresse ocorrerá uma maior concentração de GSSG e uma diminuição na razão GSH/GSSG. Nós observamos que na IRI ocorre um aumento do estresse oxidativo, visto através da diminuição da razão (GSH/GSSG) e o tratamento com acetato retorna a níveis observados no controle (Figura 4D).

4.3 Análise dos níveis de expressão gênica e da ativação da via de sinalização NF-Kb

Também avaliamos, por PCR em tempo real, os níveis de expressão de citocinas próinflamatórias e quimiocinas no tecido renal e observamos que os camundongos tratados com acetato, possuem menores níveis de mRNA das moléculas CD68 e MCP1 que são marcadores 
de macrófagos e para a citocina pró-inflamatória IL-6 e para KC ainda que para estas duas últimas, nós não observamos diferença estatisticamente significante (Figura 5A). Verificamos se esta menor produção estava associada a uma inibição da via de ativação do fator de

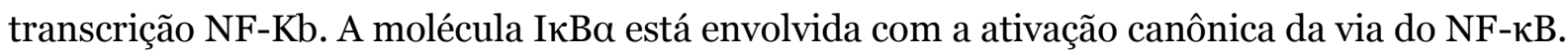
A via canônica é aquela ativada por LPS, TNF, entre outras. Uma vez ativada, a molécula I $\kappa a$ é ubiquitinada e degradada pelo proteassoma, o que permite com que o complexo migre para o núcleo e ative os genes responsivos a ele (90). Nós verificamos que o tratamento com acetato diminui a ativação desta via, através da maior quantidade (em unidades arbitrárias) da molécula IkBa no tecido renal (Figura $5^{B}$ ).
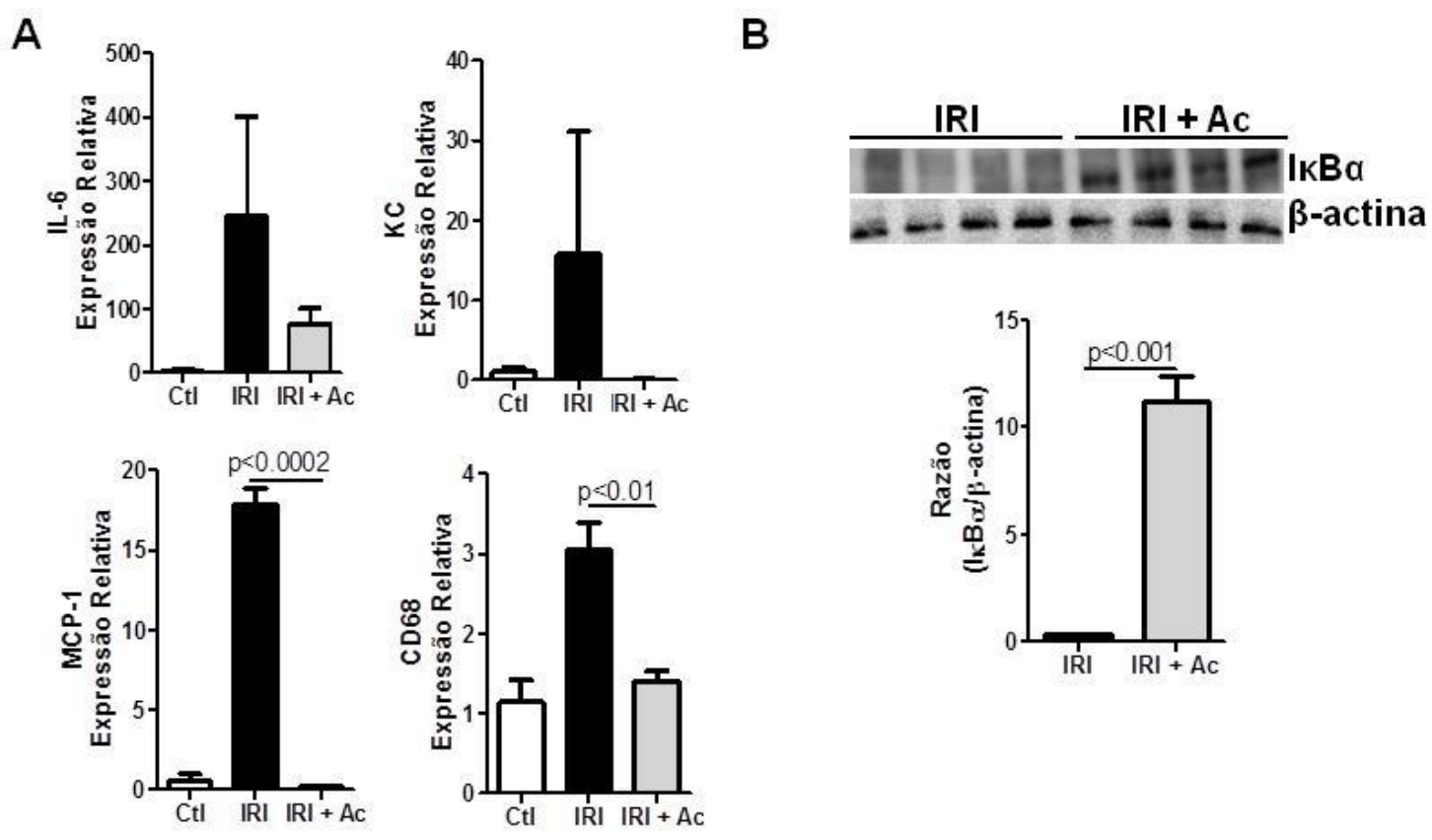

Figura 5. Nível de mRNA de moléculas pró-inflamatórias e de marcadores celulares e ativação da via de sinalização NF-kB. (A) Níveis de expressão gênica das moléculas IL-6, KC, MCP-1 e CD68 em camundongos submetidos a IRI renal tratados ou não com acetato. O nível de expressão foi normalizado pela expressão da $\beta$-actina e o grupo controle foi utilizado como calibrador.

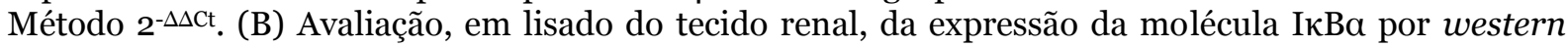
blot. A quantificação da expressão das moléculas é dada em unidades arbitrárias e o gráfico da razão do nível de expressão de IкBa pelo nível de expressão da actina nos dois grupos. Teste $t$ student IRI= isquemia reperfusão injury. $\mathrm{Ac}=$ acetato

4.4 Avaliação do infiltrado de leucócitos celular nos camundongos tratados com acetato

A observação de menores citocinas pró-inflamatórias e quimiocinas no tecido renal, tanto em nível protéico como de mRNA, juntamente com uma menor ativação de NF- $\kappa$ B nos motivou a verificar se isto estaria associado a um menor infiltrado de células do sistema imune no rim. A figura 6A mostra que em camundongos submetidos à IRI renal e tratados 
com acetato houve uma menor frequência de células $\mathrm{CD} 11 \mathrm{~b}+\mathrm{F} 4 / 80+$ (macrófagos) e uma tendência a uma menor frequência de células $\mathrm{CD} 11 \mathrm{c}+\mathrm{CD} 4 \mathrm{O}+$ (que poderiam ser macrófagos ou células dendríticas ativadas) quando comparados aos camundongos sem tratamento. Da mesma forma, a quantificação da enzima mieloperoxidase (MPO) no lisado renal, a qual serve como medida indireta da ativação de neutrófilos e macrófagos também foi observada níveis menores em camundongos tratados com acetato em relação aos não tratados (Figura 6B), o que também foi confirmado, ao menos para MPO, por imunohistoquímica (Figura 6C).

A
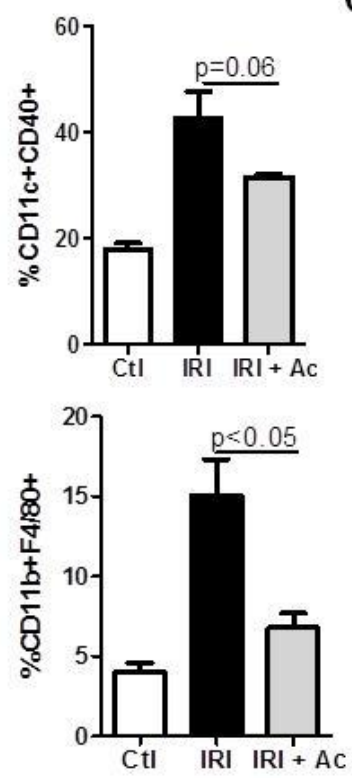

B

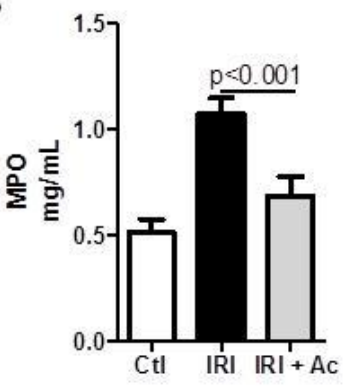

C
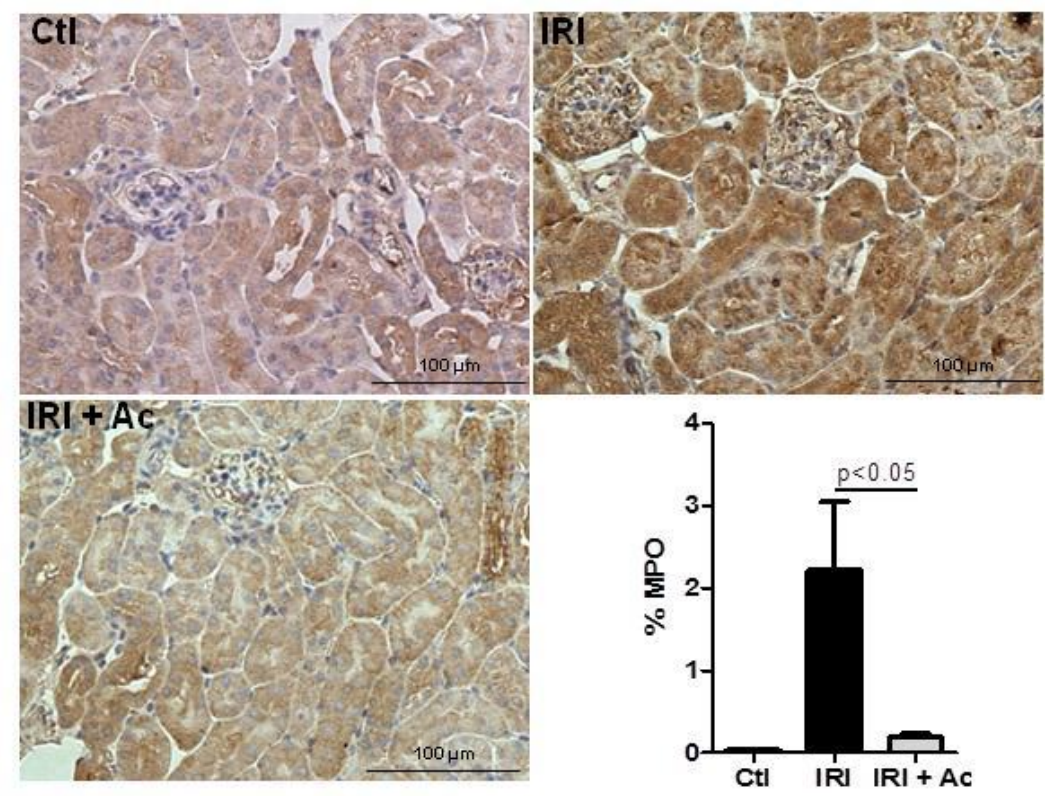

Figura 6. Avaliação do infiltrado de leucócitos no rim em camundongos submetidos à IRI renal e tratados com acetato. (A) Frequência de células $\mathrm{CD} 11 \mathrm{c}+\mathrm{CD} 4 \mathrm{O}+$ e de células $\mathrm{CD} 11 \mathrm{~b}+\mathrm{F} 4 / 80+$ a partir da purificação dos leucócitos do rim de camundongos submetidos à IRI renal e tratados com acetato. (B) Dosagem de MPO a partir da lisado renal (C) Imunohistoquímica para MPO em cortes histológicos e a \% de marcação para MPO. A quantificação foi realizada ao menos em 20 campos por rim. Teste $\mathrm{t}$ de student. $\mathrm{IRI}=$ isquemia reperfusão injury. $\mathrm{Ac}=$ acetato 
4.5 Avaliação da expressão de genes da imunidade inata e de seus ligantes endógenos

É sabido que na LRA são liberadas moléculas que podem servir de ligantes para receptores da imunidade inata, como receptores TLR4 e TLR2, e que está ativação está associada a um maior grau de lesão neste modelo (91-94). Portanto, nós verificamos a expressão desses genes e de alguns de seus ligantes endógenos na tentativa de verificar se o tratamento com o acetato modularia a produção desses receptores, o que interferiria nos sinais iniciais da inflamação decorrente da IRI. De maneira interessante, observamos que no tratamento com o acetato em camundongos submetidos à IRI renal, houve uma diminuição nos níveis de expressão de TLR4 e de seu ligante endógeno biglicano. Não observamos diferenças estatisticamente significantes na expressão de TLR2, na molécula adaptadora MYD88, e nos ligantes endógenos HMGB1 e HSP70 (Figuras 7A,B).

A
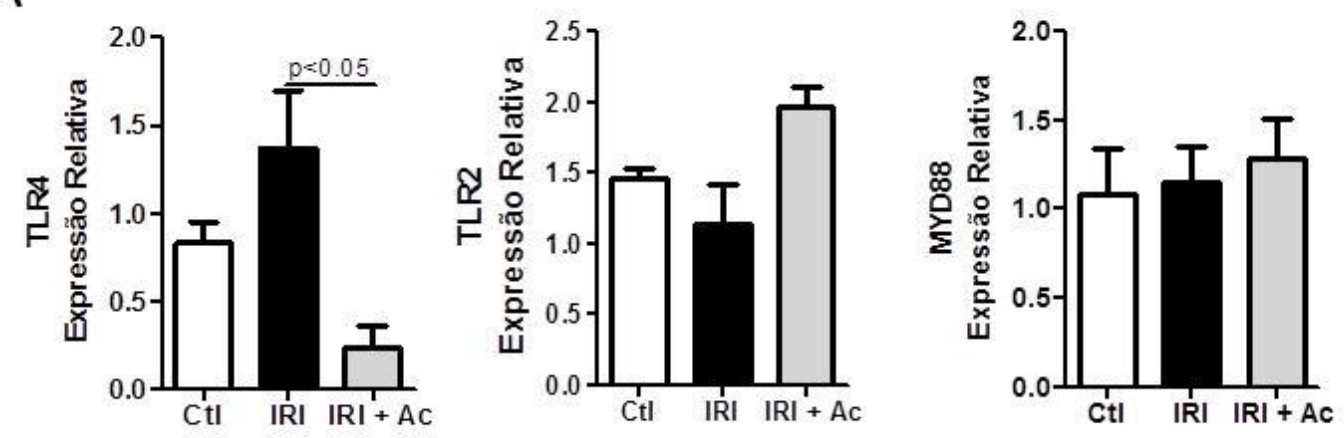

B
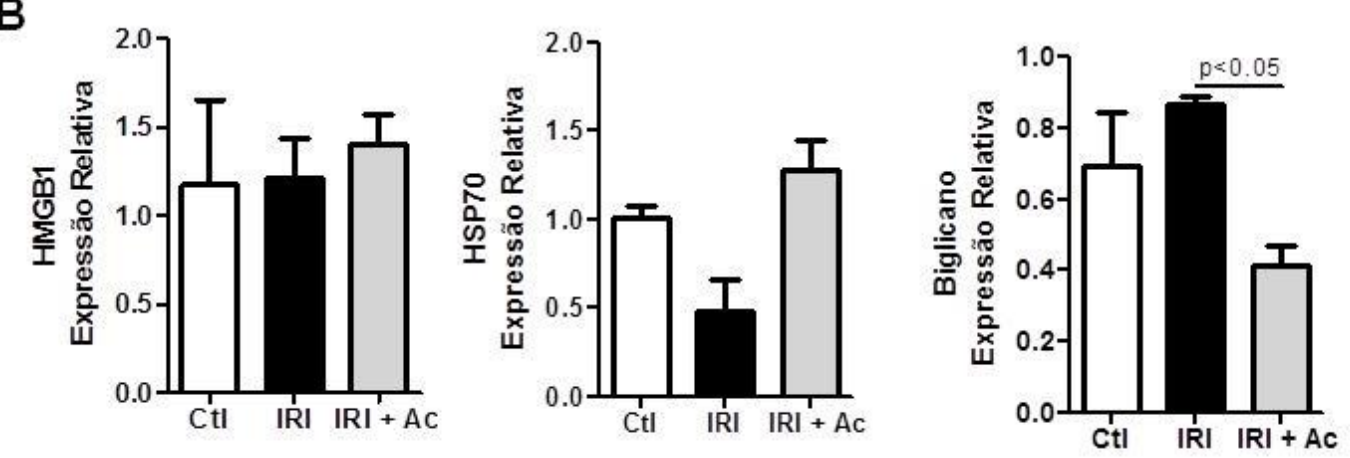

Figura 7. Níveis de expressão gênica de receptores da imunidade inata e de seus ligantes endógenos. (A) Níveis de mRNA dos receptores TLR4, TLR2 e da molécula adaptadora MYD88 em cDNA oriundo de tecido renal de camundongos tratados ou não com acetato e submetidos a IRI renal. (B) Níveis de mRNA de ligantes endógenos dos TLRs nas mesmas amostras. IRI: isquemia reperfusion injury; Ac: acetato. Em A e B os níveis de expressão foram normalizados pela expressão de $\beta$-actina e o grupo controle foi utilizado como calibrador. Método $2^{-\Delta \Delta \mathrm{Ct}}$. Teste $t$-student. 
4.6 Avaliação da apoptose e da proliferação/regeneração tecidual e conteúdo de DNA mitocondrial

Nós também avaliamos o grau de apoptose e de proliferação das células através das técnicas de TUNEL e avaliação da molécula PCNA, respectivamente. Observamos que os camundongos tratados com acetato na vigência da IRI renal possuem um menor grau de células em apoptose (Figura 8A). Da mesma forma, nesses animais também foi observado um maior marcação para a molécula PCNA, sugerindo que estas células além de não sofrerem apoptose, estão proliferando (Figura 8B). A expressão da molécula anti-apoptótica Bcl-2 estava aumentada no grupo tratado com acetato em relação ao grupo IRI (Figura 8C), ratificando o menor grau de apoptose após o tratamento com acetato.

Tem sido relatado que o tratamento com os AGCCs poderia induzir autofagia, retardando o processo de apoptose pela via mitocondrial (74). Nós observamos um aumento da molécula ATG-7, que está envolvida na formação do autofagossomo, no tratamento com acetato nos animais submetidos à IRI (Figura 8D). Também observamos que o conteúdo de DNA mitocondrial no rim dos animais tratados com acetato estava aumentado quando comparado aos animais submetidos à IRI (Figura 8E). Considerando estes resultados, nós acreditamos que o tratamento com acetato possa induzir a autofagia, inibindo o processo apoptótica, favorecendo a sobrevivência celular, o que se reflete em um maior nível no conteúdo mitocondrial. 
A

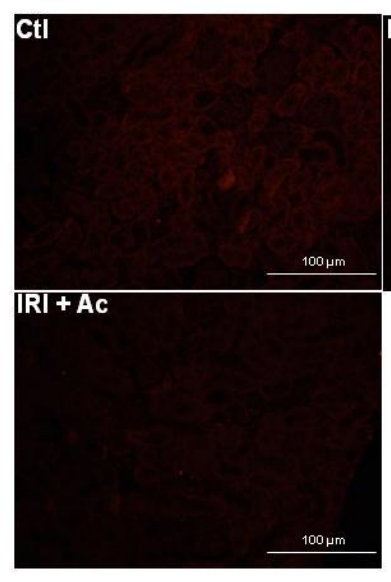

C

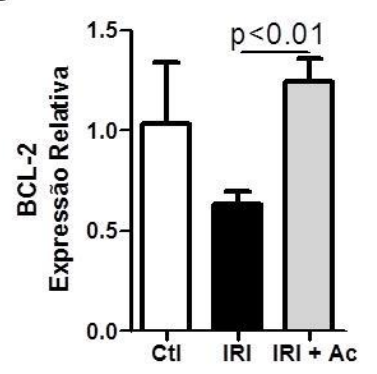

|RI
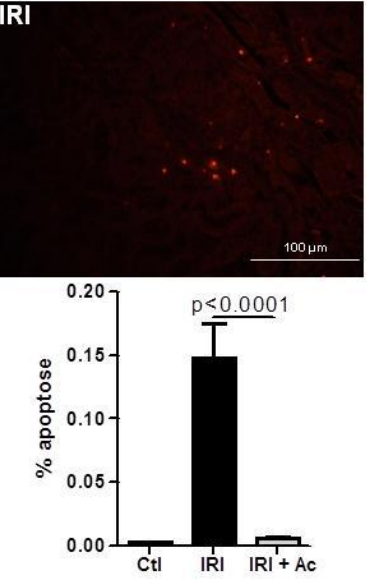

D

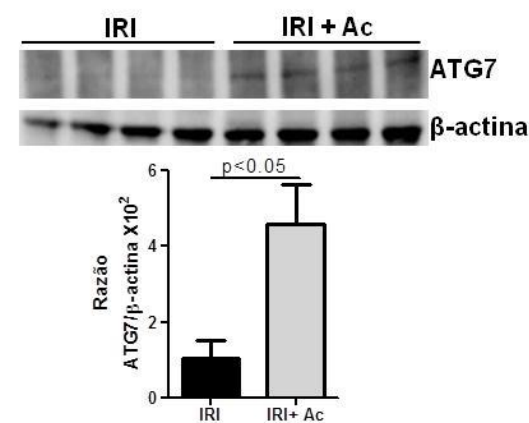

B
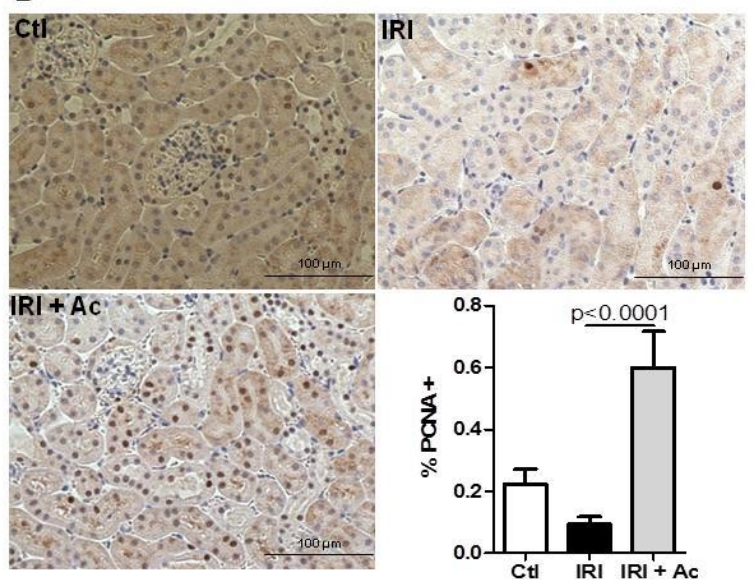

E

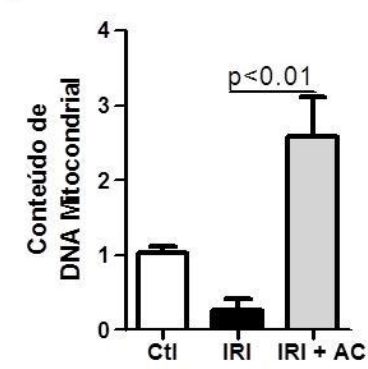

Figura 8. Avaliação do grau de apoptose e de proliferação celular e do conteúdo de DNA mitocondrial. (A) cortes histológicos foram dos grupos acima foram avaliados para o grau de apoptose através da técnica de TUNEL. A quantificação foi realizada ao menos 20 campos por rim. (B) Avaliação da proliferação celular através da marcação de PCNA nos grupos acima. A quantificação foi realizada da mesma maneira que em A. (C) expressão relativa do gene anti-apoptótico BCL-2 em amostras de tecido renal. (D) Avaliação, em lisado do tecido renal, da expressão da molécula ATG-7 por western blot. A quantificação da expressão das moléculas é dada em unidades arbitrárias e o gráfico da razão do nível de expressão de ATG-7 pelo nível de expressão da actina nos dois grupos. IRI: isquemia reperfusion injury; Ac: acetato. Teste t-student.

\subsection{Expressão dos receptores para AGCC no tecido renal}

Apesar de descrito que em humanos a expressão de GPR43 (FFar2) no rim é nula ou ausente (68), nós avaliamos a expressão dessa molécula e dos receptores GPR40 e 41, com o intuito de verificar se a proteção observada após o tratamento com o acetato na IRI renal estava associada a expressão desses receptores. Observamos que a expressão desses receptores é reduzida, por PCR em tempo real, e que nos animais submetidos à IRI ocorre uma diminuição nos níveis desses receptores (Figura 9). 

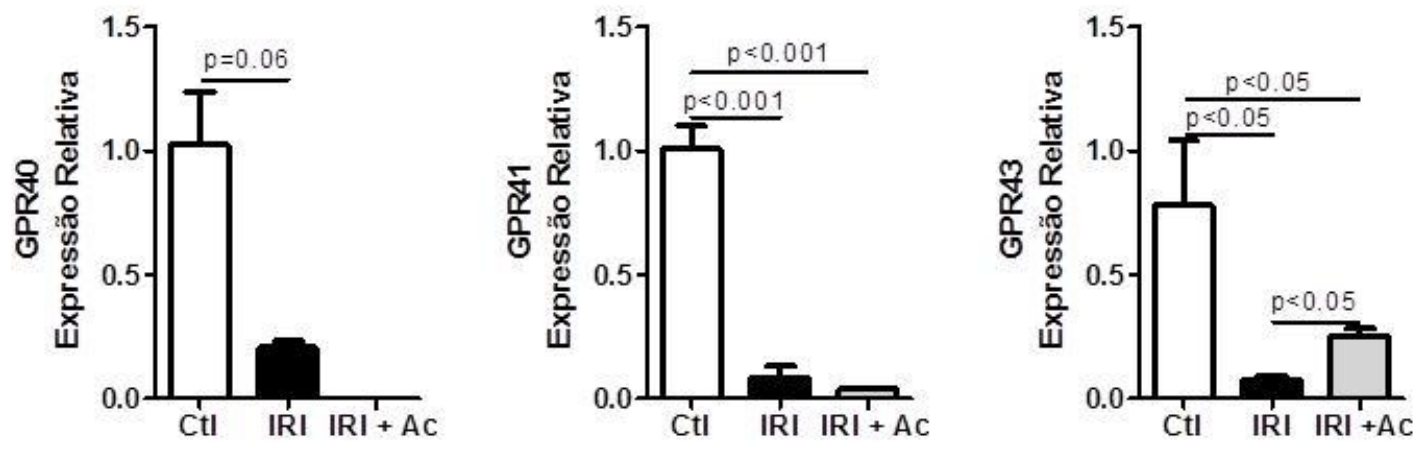

Figura 9. Nível de expressão gênica dos receptores para os AGCCs. A expressão dos receptores foi quantificado em cDNA oriundos de RNA total de tecido renal de camundongos submetidos a lesão renal de IRI tratados ou não com acetato. O nível de expressão foi normalizado pela expressão do gene $\beta$-actina e o grupo controle foi utilizado como calibrador. Método $2^{-\Delta \Delta C t}$. IRI: isquemia reperfusion injury; Ac: acetato. Teste t-student.

4.8 Avaliação da metilação do DNA, expressão gênica de moléculas envolvidas na modificação da cromatina e da atividade de histona deacetilase no tecido renal

Visto que os AGCCs podem atuar vias modificações epigenéticas, tendo sido relatado o principal mecanismo como inibidor de histona deacetilase, nós investigamos se o tratamento com o acetato modularia este processo. Foi observado que o tratamento com acetato diminuiu a atividade de histona deacetilase nos camundongos submetidos à IRI renal (Figuras 10A e B). Nós também avaliamos a expressão de 84 genes envolvidos na modificação da cromatina. Observamos que na isquemia ocorreu a modulação de 22 genes, sendo 4 genes tiveram sua expressão aumentada e 18 diminuída. Observamos que na comparação entre o grupo tratado com acetato em relação ao controle havia menos genes diferencialmente expressos. Já na comparação entre os grupos IRI vs IRI mais o tratamento com acetato, observamos que $10 \%$ do total de genes analisados estavam diferencialmente expressos (Figura 10A). Realizamos uma análise de comparação entre os três grupos e observamos que os genes que estavam aumentados ou diminuídos na lesão de isquemia, retornavam sua expressão após o tratamento com acetato (Figura 10B). Dentre os genes modulados, nenhum está relacionado com a transcrição de genes que codificam as enzimas com atividade de histona deacetilase. Além disso, observamos que a metilação global do DNA no tecido renal estava diminuída após a lesão de isquemia e reperfusão e o tratamento com acetato aumentou a percentagem de metilação global (Figura 10D). Desse modo, é possível que o mecanismo de ação do acetato na melhora da lesão renal in vitro seja através da modulação epigenética. 
A
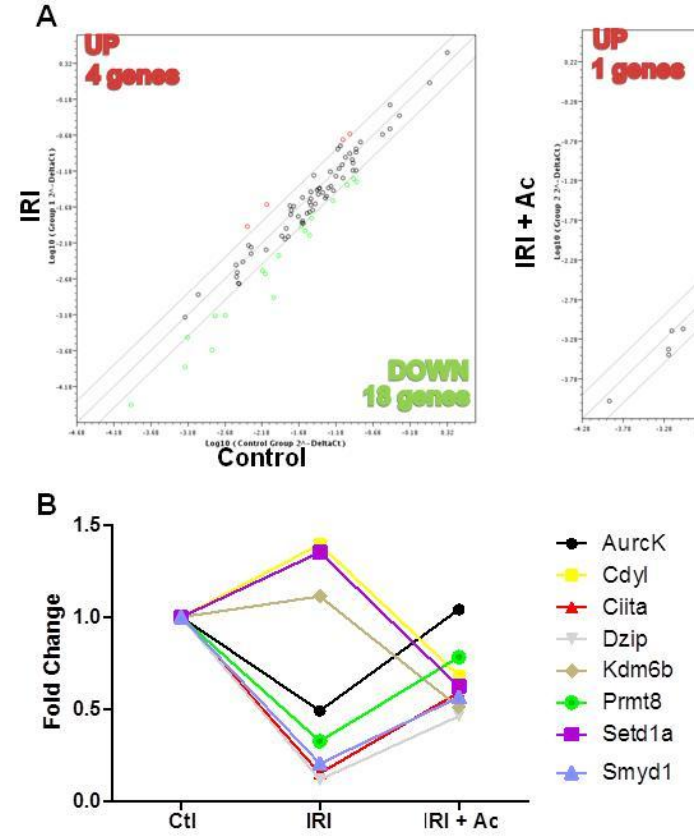

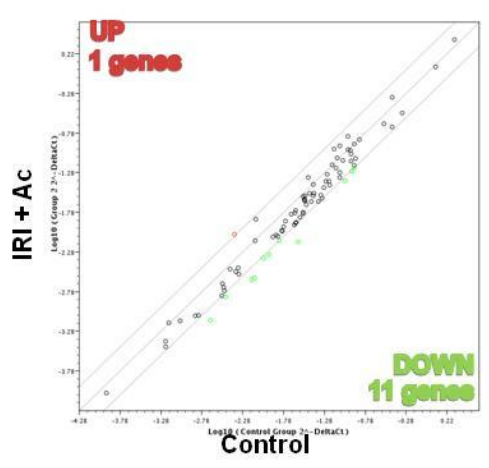

C

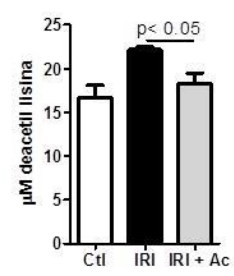

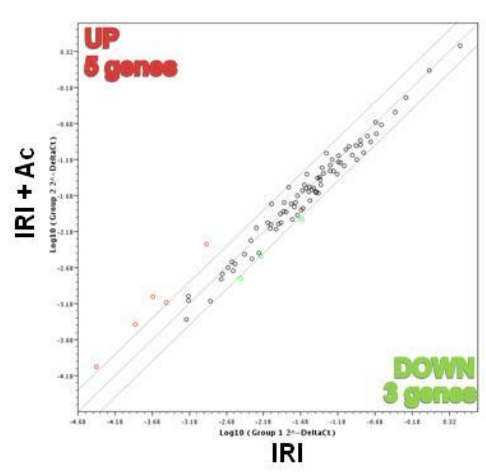

D

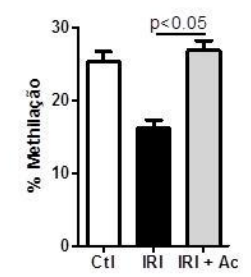

Figura 10. Avaliação da expressão de genes relacionados com modificação epigenética, da atividade da histona deacetilase e do perfil de metilação. (A) Comparação do perfil de expressão de genes relacionados com modificação da cromatina entre IR vs controle (esquerda), IR+Ac vs. controle (centro) e IR vs. IR+Ac (a direita) em amostras de tecido renal. Genes up (pontos em vermelho) e down (pontos em verde) regulados são em relação ao grupo que está no eixo da coordenada. (B) Variação da expressão de 8 genes diferencialmente expressos entre os grupos IR vs. IR+Ac em relação a todos os grupos. (C) Medida da atividade de histona deacetilase em tecido renal. (D) \% de metilação do DNA nas amostras de tecido renal. As amostras foram digeridas com enzimas sensíveis ou não a metilação e a \% da metilação foi calculada (descrito em métodos). IRI: isquemia reperfusion injury; Ac: acetato. Teste t-student.

4.9 Avaliação do tratamento de AGCCs na maturação de células dendríticas derivadas da medula óssea

Sabe-se que dentre as várias subpopulações de leucócitos, cada uma tem sua importância na LRA, pois suas ausências contribuem para melhora da lesão (17). Além disso, nós observamos uma menor frequência de células apresentadoras de antígenos em camundongos tratados com AGCC, nós verificamos se o mesmo ocorreria in vitro. $\mathrm{O}$ tratamento com todos os AGCC, acetato, butirato e propionato, reduziu a proporção de células positivas para marcadores de maturação de células dendríticas como CD80 e CD40 (Figura 11A) bem como os seus níveis de expressão (Figura 11B) após estímulo com LPS. 
A

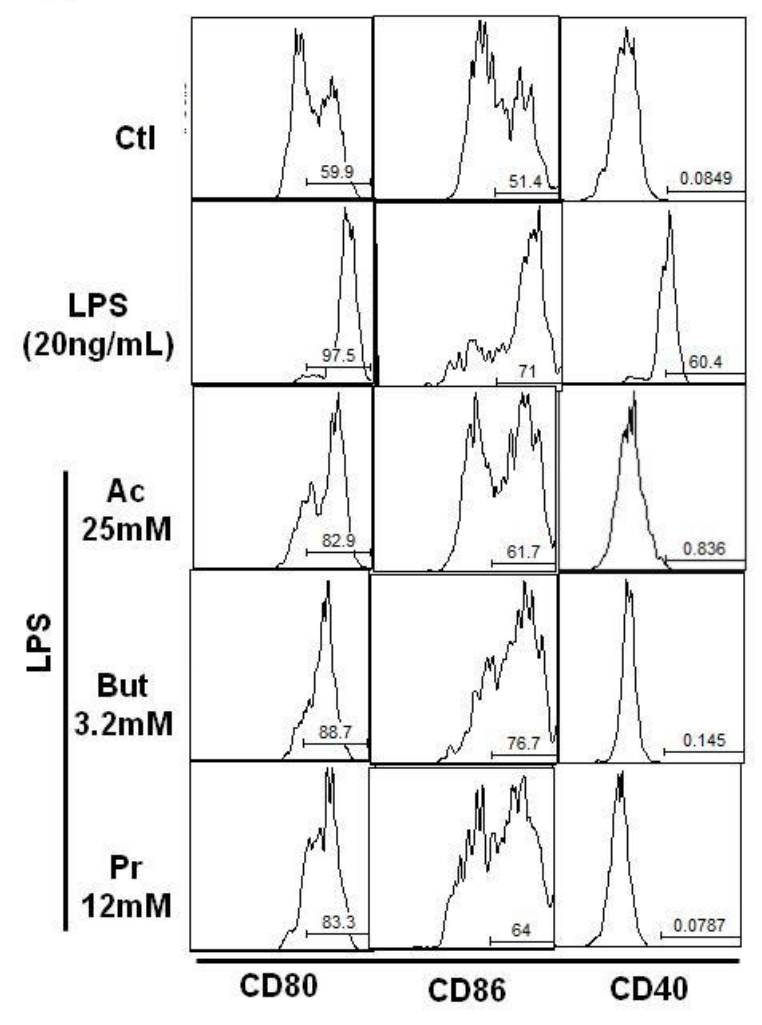

B
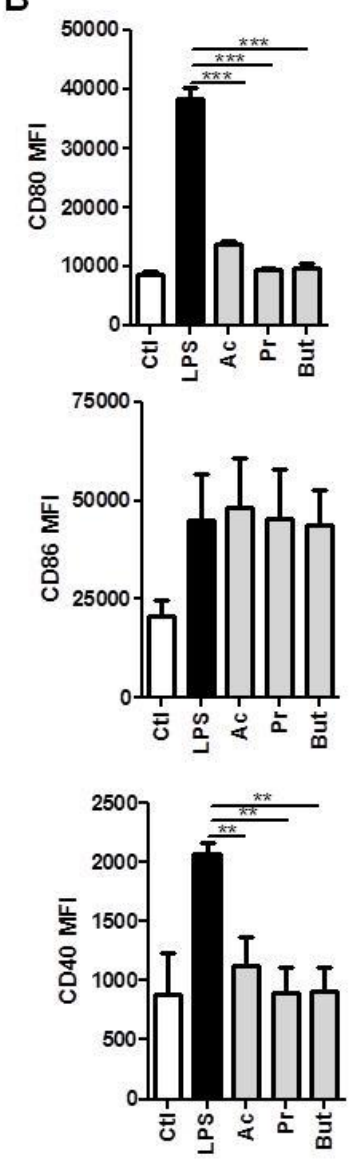

Figura 11. Avaliação do tratamento com AGCC na maturação de células dendríticas derivadas da medula óssea. Células derivadas da medula óssea foram colocadas em cultura por 6 dias na presença de GM-CSF ( $20 \mathrm{ng} / \mathrm{mL}$ ). No sexto dia de cultura, as células foram estimuladas com LPS, na presença ou ausência de Acetato (25mM); Propionato (12 mM) e Butitrato (3,2 mM) por 24h. (A) Histograma da análise de células positivas para a molécula CD80 e CD86 e CD40. (B) Mediana da intensidade de fluorescência para a expressão do CD80, CD86 e CD40. Ac: acetato, Prop: propionato, But: butirato NE: não estimulado.

As doses escolhidas foram baseadas em estudo de migração de neutrófilos (69, 70).

4.10 Avaliação da capacidade proliferativa de esplenócitos frente a um estímulo específico e a um estímulo policlonal

Também verificamos se o tratamento com AGCC, na mesma dose utilizada para células dendríticas, inibiria a capacidade de proliferação de esplenócitos frente a estímulos específicos e a estímulos policlonais (Figura 12). Observamos que na presença de estímulo policlonal (anti-CD3 + anti-CD28), os AGCC inibiram a proliferação de células T CD4+. Já para inibição antígeno específica (OVA), observamos uma redução na proliferação somente para propionato e butirato. 


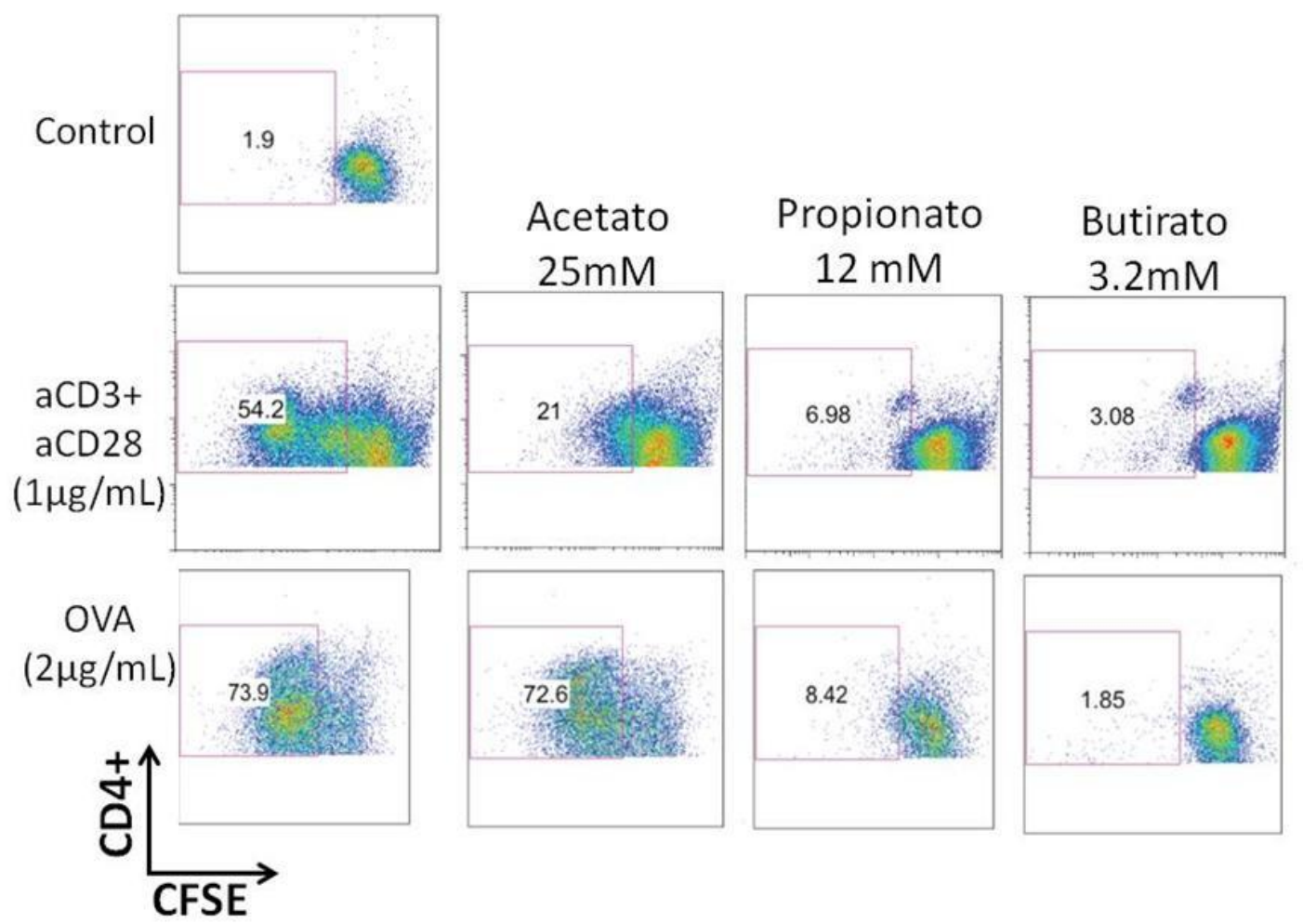

Figura 12. Avaliação da proliferação de esplenócitos in vitro na presença dos AGCCs. Esplenócitos de camundongos OT-II os quais possuem TCR específico para o antígeno ovalbumina foram marcados com CFSE e colocados em cultura na presença do seu estímulo específico (ovalbumina) ou com estímulo policlonal (anticorpos anti-CD3 e anti-CD28) na presença ou não de butirato $(3,2 \mathrm{mM})$, propionato $(12 \mathrm{mM})$ e acetato $(25 \mathrm{mM})$ por 4 dias para avaliar sua proliferação.

4.11 Avaliação na modulação da maturação das células apresentadoras de antígenos pelos AGCCs na sua capacidade de induzir a proliferação de células alogênicas

Tendo observado a modulação das células apresentadoras de antígenos derivadas da medula óssea pelos AGCC, nós verificamos se esta modulação era capaz de inibir a proliferação de linfócitos $\mathrm{T}$ em um modelo alogênico. Observamos que o tratamento de esplenócitos derivados de camundongos RAG KO (doador de células apresentadoras de antígeno, APCs) com os AGCC na presença de LPS por $24 \mathrm{~h}$ inibiu a proliferação tanto de linfócitos T CD4+ quanto de linfócitos T CD8+ de camundongos Balb/c (estímulo alogênico, figuras 13A e B). A modulação mais evidente ficou por conta das APCs pré-tratadas com butirato e propionato. Após os dois tratamentos, observou-se uma grande redução na proliferação tanto das células T CD4+ quanto de células T CD8+. 
A

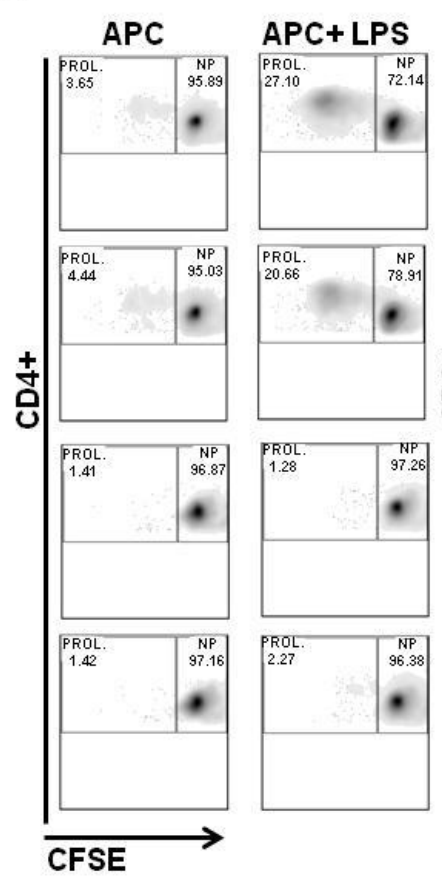

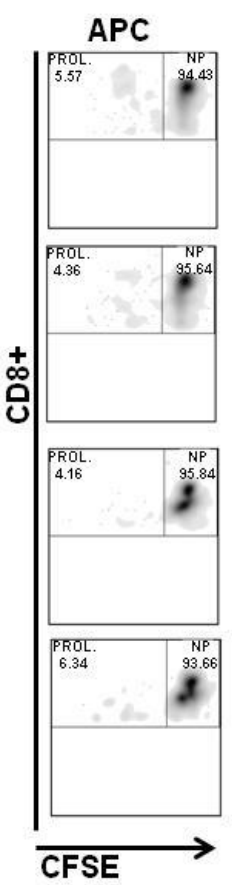

APC + LPS No APC
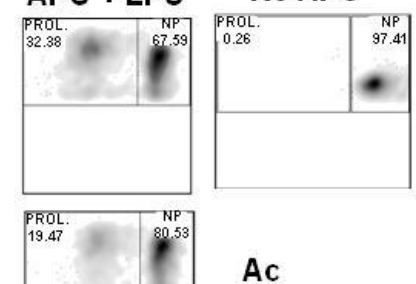

$25 \mathrm{mM}$
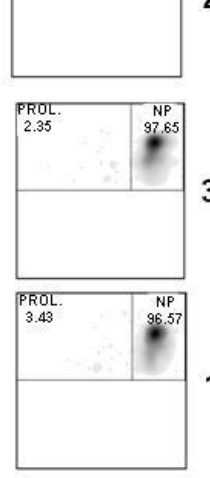

B
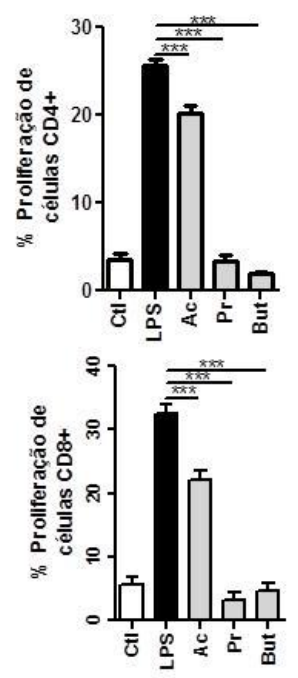

Figura 13. Proliferação de células $\mathrm{CD4}+$ e CD8+ em um contexto alogênico quando cocultivadas com células apresentadoras de antígenos tratadas com AGCCs. (A-B) Esplenócitos de camundongos RAG knockout (células apresentadoras de antígenos - APC) foram purificados e estimulados com LPS $(20 \mathrm{ng} / \mathrm{mL})$ na presença de butirato $(3,2 \mathrm{mM})$, propionato $(12 \mathrm{mM})$ e acetato $(25 \mathrm{mM})$ por $24 \mathrm{~h}$. Após este período, as células foram lavadas para retirada do AGCC e colocadas em co-cultivo com esplenócitos de Balb/c marcados com CFSE por 4 dias. (A) O grágico mostra a proliferação de células CD4+ e CD8+(B) Gráfico de percentagem de células CD4+ e CD8+ proliferando. Prol: células em proliferação; NP: células que não proliferaram.

Já para o pré-tratamento das APC com acetato ocorreu uma menor inibição da proliferação dessas células. De fato, na modulação da maturação de células dendríticas derivadas da medula óssea com acetato nós também observamos uma menor modulação na expressão de moléculas co-estimulatórias.

Portanto, os AGCC modulam a ativação e função de APCs e também inibem a proliferação de esplenócitos, ou seja, eles modulam células do sistema imune, que são importantes no processo de desencadeamento da função renal.

4.12 Avaliação da inflamação em linhagem de célula epitelial renal após o tratamento com os AGCC

Outro evento importante no processo de LRA é a ativação do endotélio e do epitélio renal frente a uma agressão isquêmica ou tóxica, com produção de citocinas e quimiocinas inflamatórias, que recrutarão novas células do sistema imune. Já foi demonstrado que os AGCC podem atuar em linhagens de células de cólon (74) ou em linhagem imortalizada de mama (95), mas não em células renais. Para verificar se os AGCCs eram, em primeiro lugar, 
capazes de atuar diretamente em células renais, nós estimulamos linhagem de células epitelial renal com um estímulo inflamatório, com o propósito de mimetizar o microambiente in vivo que esta célula está quando da ocorrência de uma LRA, na presença dos AGCC, acetato, propionato e butirato, e fomos observar a ativação de NF- $\kappa$ B. Nós observamos que o tratamento com o estímulo inflamatório aumentou a ativação de NF- $\kappa \mathrm{B}$ e que o tratamento com os AGCCs a reduziu (Figura 14A). Do mesmo modo, observamos que a produção de NO também estava diminuída nestas células sob estímulo inflamatório e tratadas com os AGCC (Figura 14B). Portanto, os AGCC podem atuar nas células renais e podem conter a ativação de $\mathrm{NF}-\kappa \mathrm{B}$, o que auxiliaria em uma menor produção de citocinas e quimiocinas inflamatórias.

A
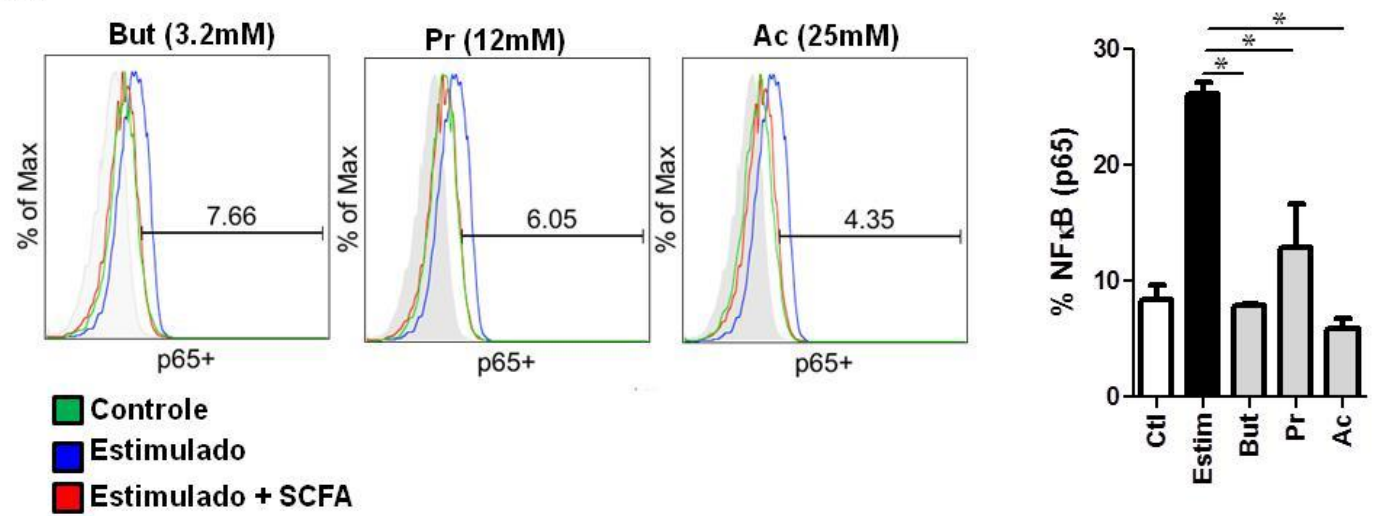

B
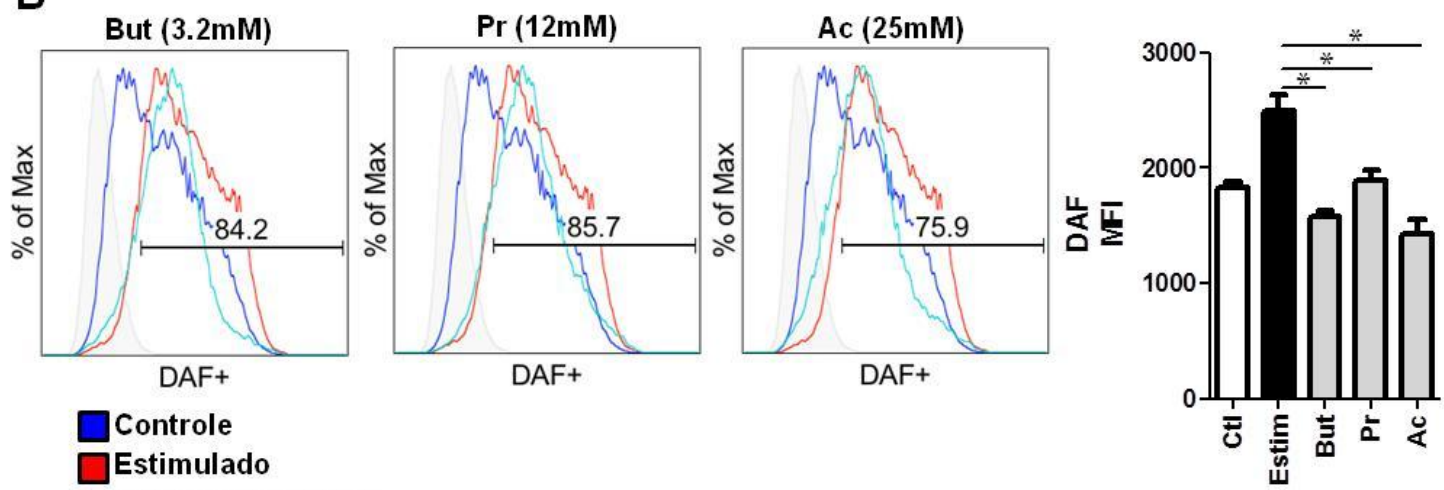

Controle

$\square$ Estimulado

Estimulado + SCFA

Figura 14. Avaliação da inflamação em linhagem de células epiteliais renais. Linhagem de célula epitelial renal de camudongo (MM55.k) foram estimuladas com LPS, IL-6, IL1- $\beta$, Zimosan e TNF- $\alpha$ e tratadas com AGCC por 24h. (A) analíse, histograma por citometria de fluxo, da \% de células positivas para a subunidade p65 do NF-кB. (B) dosagem indireta de óxido nítrico. Histograma da positividade em relação a células não marcada. Mean Fluorescence Intensitty (MFI) da intensidade para as células positivas. But 3.2mM : células tratadas com butirato na concentração de $3.2 \mathrm{mM}$; $\mathrm{Pr}$ 12mM: células tratadas com propionato na concentração de $12 \mathrm{mM}$; Ac $25 \mathrm{mM}$ : células tratadas com acetato na concentração de $25 \mathrm{mM}$. Ctl: controle não estimulado. Est: estimulado. But: estimulado e tratado com butirato; Prop: estimulado e tratado com propionato. Ac: estimulado e tratado com acetato. 
4.13 Avaliação do processo de hipóxia, da ativação de HIF-1a e da produção de lactato em células epiteliais renais

No processo de lesão isquêmica ocorre a liberação de ROS e a ativação do endotélio e de células do sistema imune residentes no rim. Nós submetemos as células MM55.k ou as HK-2, ambas linhagens epiteliais imortalizadas de rim de camundongo e humano, respectivamente, à 24 horas de hipóxia na presença ou não dos AGCC. Utilizamos o hipoxiprobe como marcador de hipóxia e observamos que após $24 \mathrm{~h}$ as células estão totalmente marcadas, e que o tratamento com os AGCCs diminuiu a marcação (Figura 15). Da mesma maneira, na isquemia ocorre a perda da fosforilação oxidativa pelas mitocôndrias e foi possível observar através do mitosox (marca a produção de superóxido pelas mitocôndrias), que após $24 \mathrm{~h}$ ocorre uma diminuição da marcação e o tratamento com os AGCCs melhora o funcionamento mitocondrial (Figura 15). 


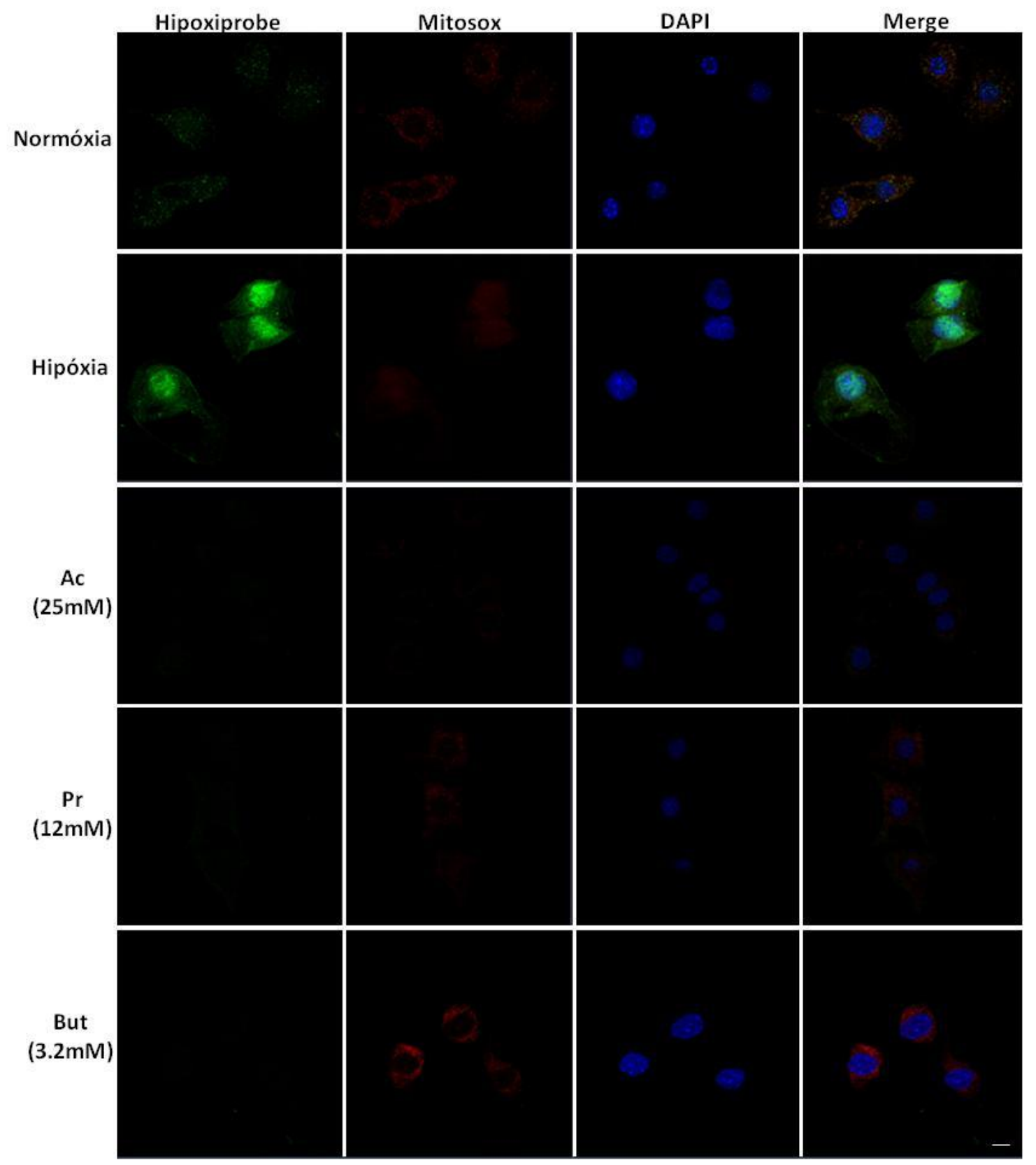

Figura 15. Hipóxia em células epiteliais tratadas com AGCC. Células HK-2 (humana) foram submetidas à $24 \mathrm{~h}$ de hipóxia e tratadas com os AGCC conforme as concentrações acima. Células foram marcadas com hipoxiprobe, mitosox e DAPI e analisadas por microscopia confocal. Ac: acetato; Pr: propionato; Ac: acetato.

A molécula HIF-1a está entre um dos principais fatores de transcrição envolvidos no processo de hipóxia, pois na ausência de oxigênio, ela transloca para o núcleo regula a transcrição de diversos genes (96). Desse modo, nós verificamos que o tratamento com os AGCCs nas células submetidas à hipoxia diminui a translocação de HIF-1a para o núcleo (Figura 16A). 


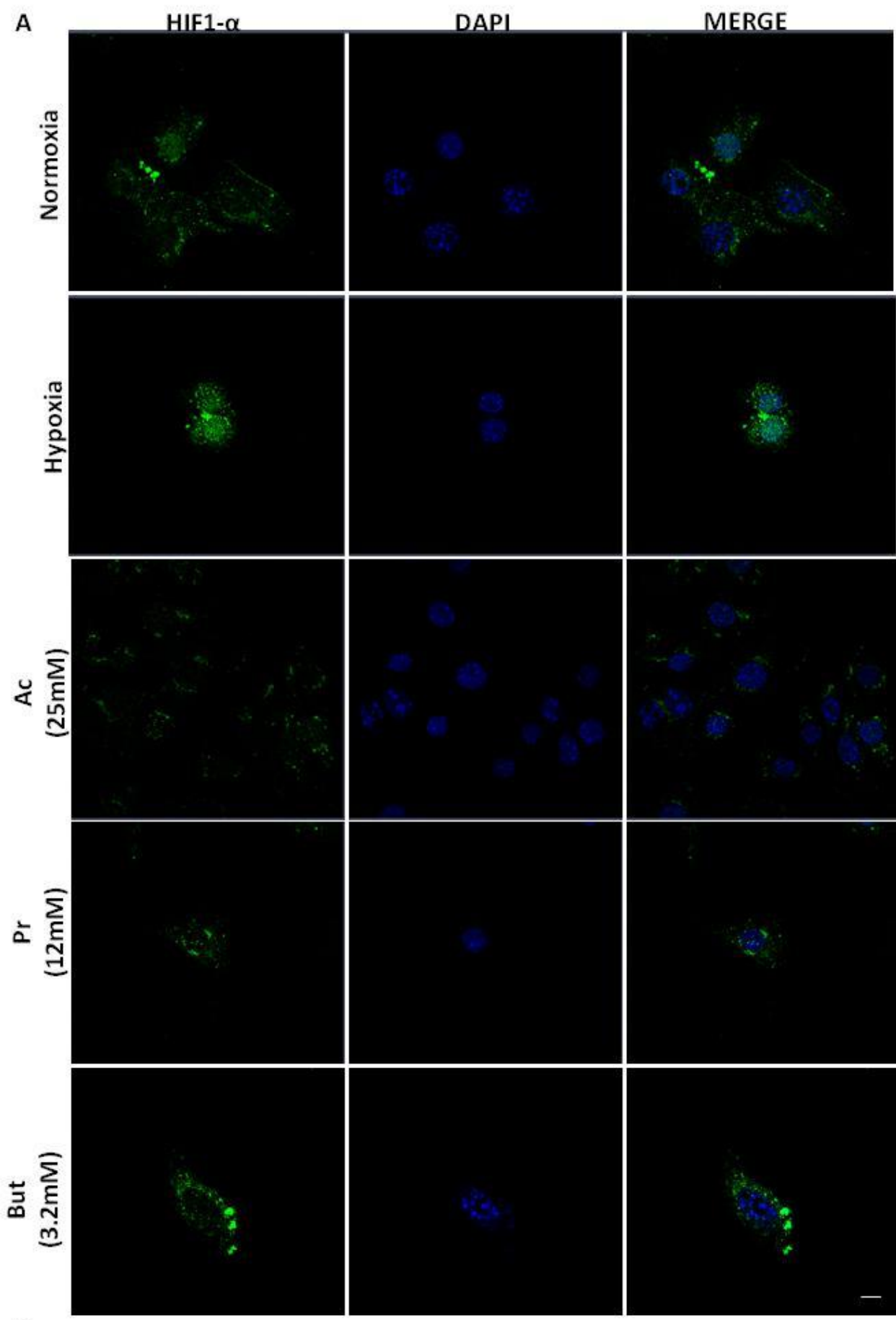

B

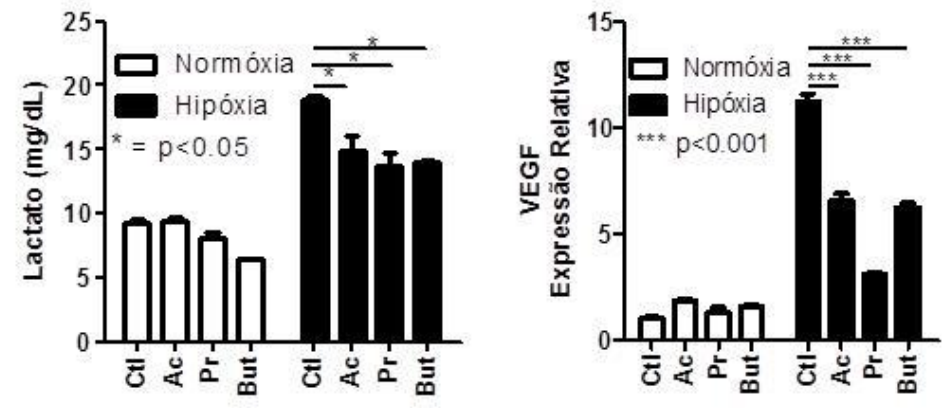


Figura 16. Análise de ativação de HIF-1a, expressão de VEGF e dosagem de lactato. Células epiteliais renais foram submetidas à 24 horas de hipóxia e tratados ou não com AGCC. (A) Imagem de microscopia confocal para HIF-1a. (B) Níveis de VEGF medidos por real time PCR. (C) Níveis de lactato no sobrenadante das células submetidas ou não à hipóxia e tratadas ou não com AGCCs. But: butirato; Pr: propionato; Ac: acetato; Ctl: controle.

Esta menor ativação de HIF-1 $\alpha$ foi também corroborada pela menor expressão do gene VEGF nessas células, que é um gene positivamente regulado pela ativação do HIF-1a (97) (Figura 16B). Nós também observamos que ocorre uma diminuição na produção de lactato no meio das células submetidas à hipóxia e tratadas com AGCCs (Figura 16B). Dessa maneira é possível inferir que o tratamento com os AGCCs diminuem os efeitos da hipóxia nas células epiteliais renais.

4.14 Administração dos probióticos Bifidobacterium longum e Bifidobacterium adolescentis na LRA

As bactérias $B$. longum e $B$. adolescentis são produtoras de acetato (60). Nós realizamos a administração de aproximadamente $10^{8}$ de cada bactéria durante 10 dias e submetemos os animais a LRA. Este tratamento aumentou os níveis de acetato no conteúdo cecal e no soro dos animais (Figuras 17 A e B). Não foi observado diferenças na variação de peso nem na ingestão alimentar (Figuras $17 \mathrm{C}$ e D). O tratamento também não alterou a função renal nos animais controle, pois os níveis de ureia e creatinina séricas mantiveram-se inalterados na comparação entre os períodos pré e pós-tratamento com a bactéria (Figura $17 \mathrm{E})$. 
A
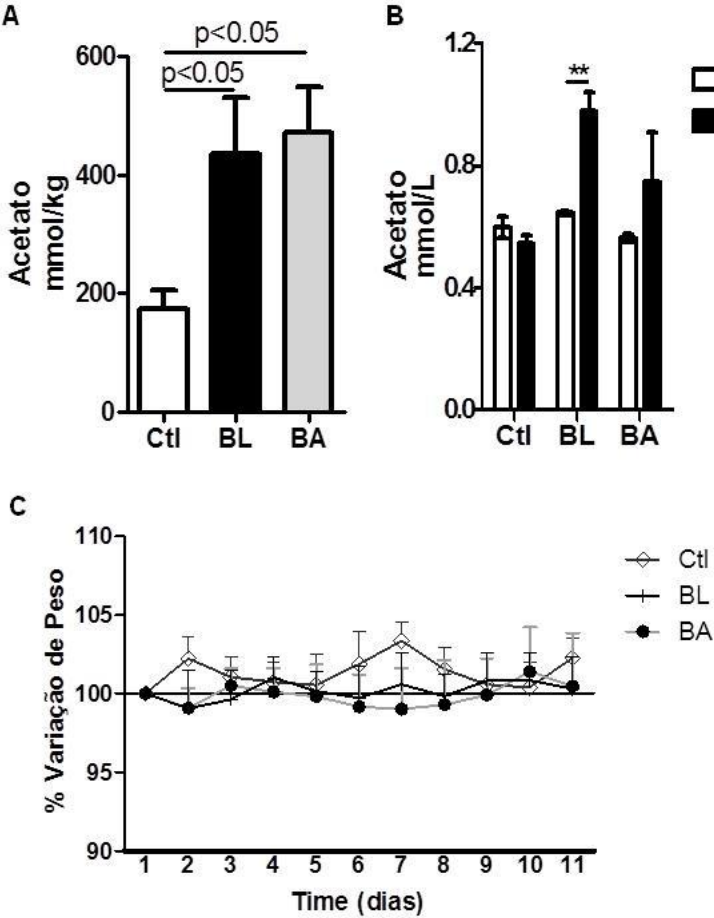

B

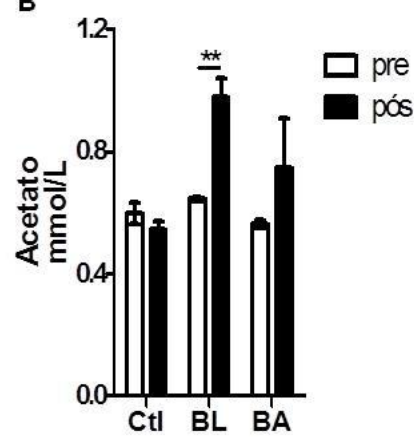

D

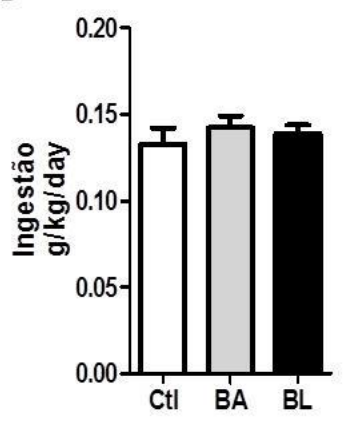

$E$

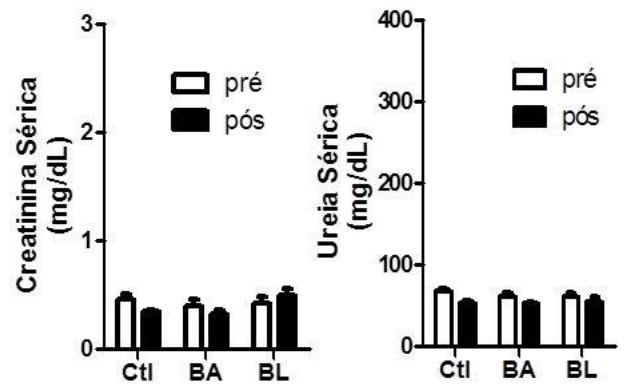

Figura 17. Tratamento com próbiotico Bifidobacterium longum (BL) e Bifidobacterium adolescentis (BA) aumenta os níveis de acetato sem prejudicar a função renal. Animais foram tratados com B. longum ou B. adolescentis durante 10 dias até o dia do sacrifício. (A) Níveis de acetato no conteúdo cecal dos animais tratados com os probióticos. (B,E) Níveis de acetato(B) e de creatinina e ureia séricos pré- e pós tratamento com a bactéria. (C,D) Variação de peso (C) e ingestão alimentar (D) dos animais durante o tratamento. (F) Creatinina e ureia sérica após tratamento com os probióticos e indução da isquemia e reperfusão. (G) Níveis séricos das citocinas IL-1 a IL-6 e MCP-1 dos animais pós-tratamento com os probióticos e indução da isquemia reperfusão. Ctl: animais controles não tratados com o probiótico.

No entanto, o tratamento com as bactérias protegeu os animais da lesão renal após a isquemia e reperfusão (Figura 18A). Esta melhora esteve associada a menores níveis de citocinas no soro dos animais tratados com as bactérias quando comparados aos animais sem tratamento (Figura 18B). 
A
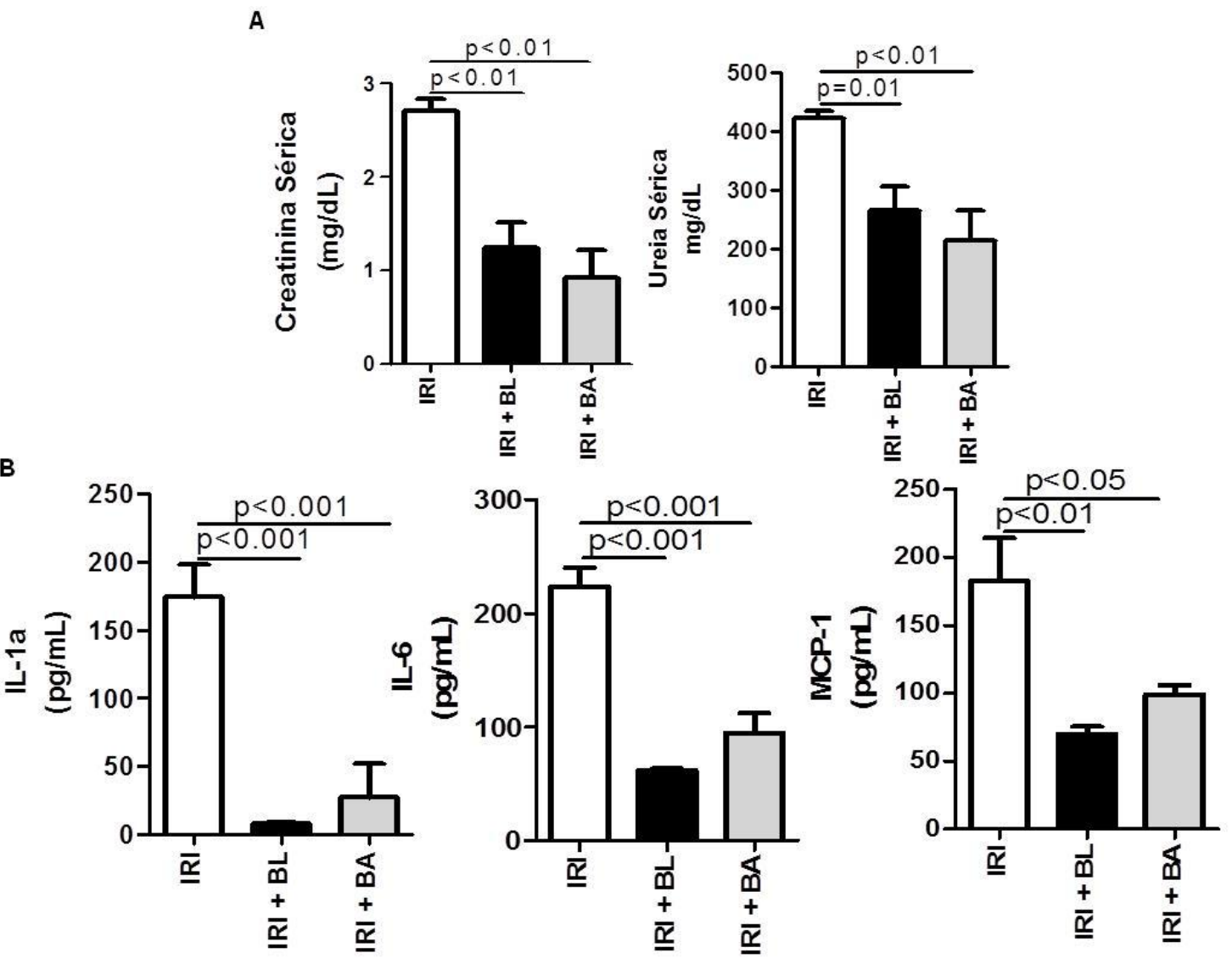

B

Figura 18. Tratamento com próbiotico Bifidobacterium longum (BL) e Bifidobacterium adolescentis (BA) protege os animais da IRI. Animais foram tratados com $B$. longum ou $B$. adolescentis durante 10 dias antes da indução da IRI renal até o dia do sacrifício. (A) Creatinina e ureia séricas. (B) Níveis séricos das citocinas IL-1a, IL-6 e MCP-1 dos animais pós-tratamento com os probióticos e indução da isquemia reperfusão. Ctl: animais controles não tratados com o probiótico.IRI= isquemia reperfusion injury, Teste $T$ de student

Portanto, o tratamento com as bactérias eleva os níveis de acetato nos animais e protege da LRA, sendo uma promissora ferramenta para modulação de processos inflamatórios 
4.15 Avaliação da lesão renal secundária à sepse em camundongos tratados com acetato

A próxima etapa foi verificar se a proteção conferida pelo acetato era somente em um único modelo. Então, nós avaliamos se o tratamento com o acetato protegeria camundongos da LRA secundária à sepse. Focamos no tratamento com este AGCC, pois na literatura já foi demonstrado o efeito do butirato em ratos e camundongos neste modelo $(88,89)$. Seguimos protocolos recentes de tratamento com butirato e o nosso no modelo de isquemia reperfusão, tratando os camundongos com $200 \mathrm{mg} / \mathrm{kg}$ de acetato, $1 \mathrm{~h}$ antes, $6 \mathrm{~h}$ pós cirurgia. Não observamos proteção com este tipo de tratamento, quando avaliamos o nível de creatinina sérica. Aumentamos a dose do acetato para $400 \mathrm{mg} / \mathrm{kg}$ e também o número de doses, sendo 1 dia antes, no momento da cirurgia e $6 \mathrm{~h}$ pós cirurgia e verificamos que os níveis séricos de creatinina e uréia estavam diminuídos em relação ao grupo não tratado (Figuras 19A e B). Nestes últimos casos, foi possível observar que os camundongos tratados com acetato têm uma maior sobrevida (Figura 19C). 
A

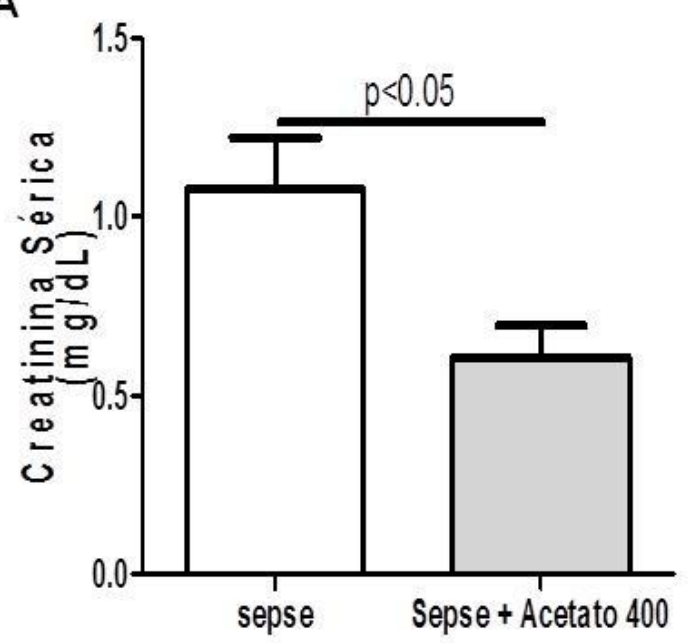

B

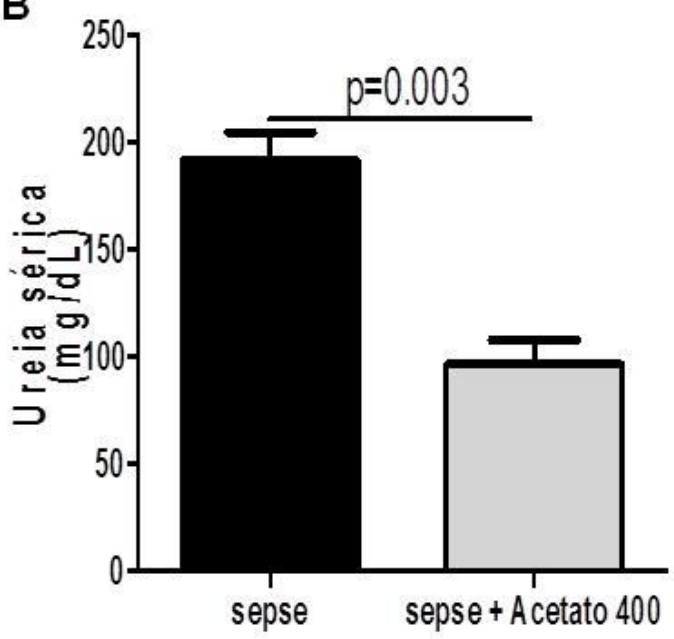

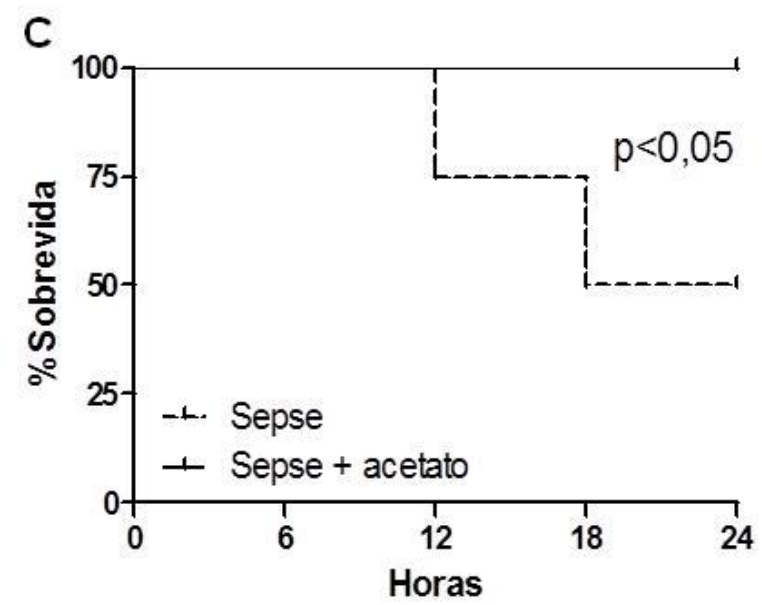

Figura 19. Função renal e sobrevida nos camundongos tratados com acetato e submetidos à sepse. (A) Níveis séricos de creatinina de camundongos que foram submetidos à sepse e tratados ou não com $200 \mathrm{mg} / \mathrm{kg}$ de acetato por $2 \mathrm{X}$ ou com $400 \mathrm{mg} / \mathrm{kg}$ de acetato por $3 \mathrm{X}$. (B) Nível de uréia sérica em camundongos tratados com acetato com $400 \mathrm{mg} / \mathrm{kg}$ de animal submetidos a sepse. (C) Curva de sobrevida em $24 \mathrm{~h}$ da sobrevida dos animais tratados com acetato ou não. Teste tstudent em A e B e Log-rank test em C.

4.16 Avaliação da inflamação sistêmica, do infiltrado inflamatório no lavado peritoneal e no rim dos camundongos submetidos à sepse

Para melhor caracterizar a melhora observada no tratamento com acetato após a sepse, nós avaliamos as citocinas inflamatórias no soro desses animais e observamos que o tratamento com o acetato diminuiu os níveis das moléculas inflamatórias IL-6 e IL-1 $\beta$ e não observamos diferenças na produção de IL-12p70 e IL-10 (Figura 20A). A diminuição de moléculas inflamatórias nos animais tratados com acetato esteve acompanhada de uma menor frequência de células inflamatórias, como neutrófilos, macrófagos, e células dendríticas no lavado peritoneal (Figura 20B). Já no rim, não observamos diferenças na 
frequência de neutrófilos (Ly6G+) e macrófago (CD11b+), mas observamos uma maior frequência de células dendríticas (CD11c+) nos animais tratados com acetato (Figura 20C).

A

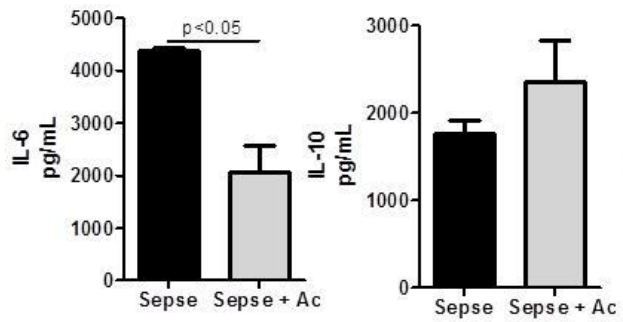

B
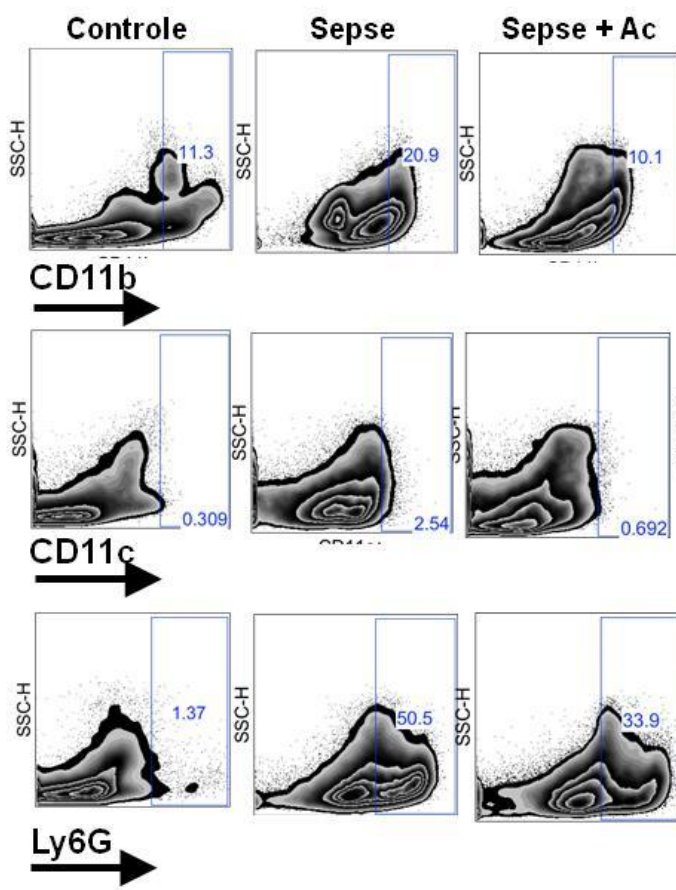

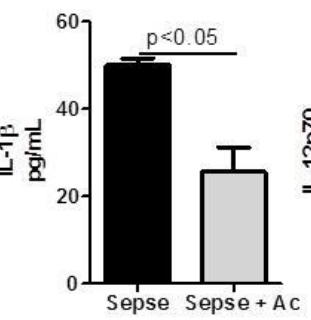

Sepse Sepse +Ac
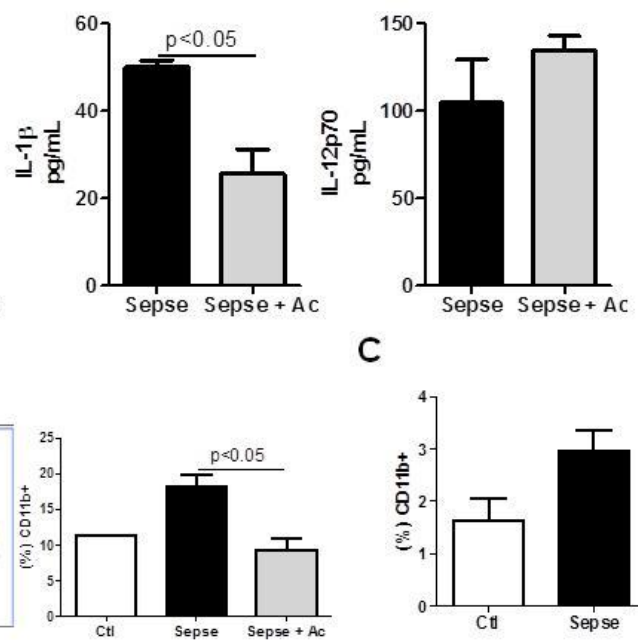

C
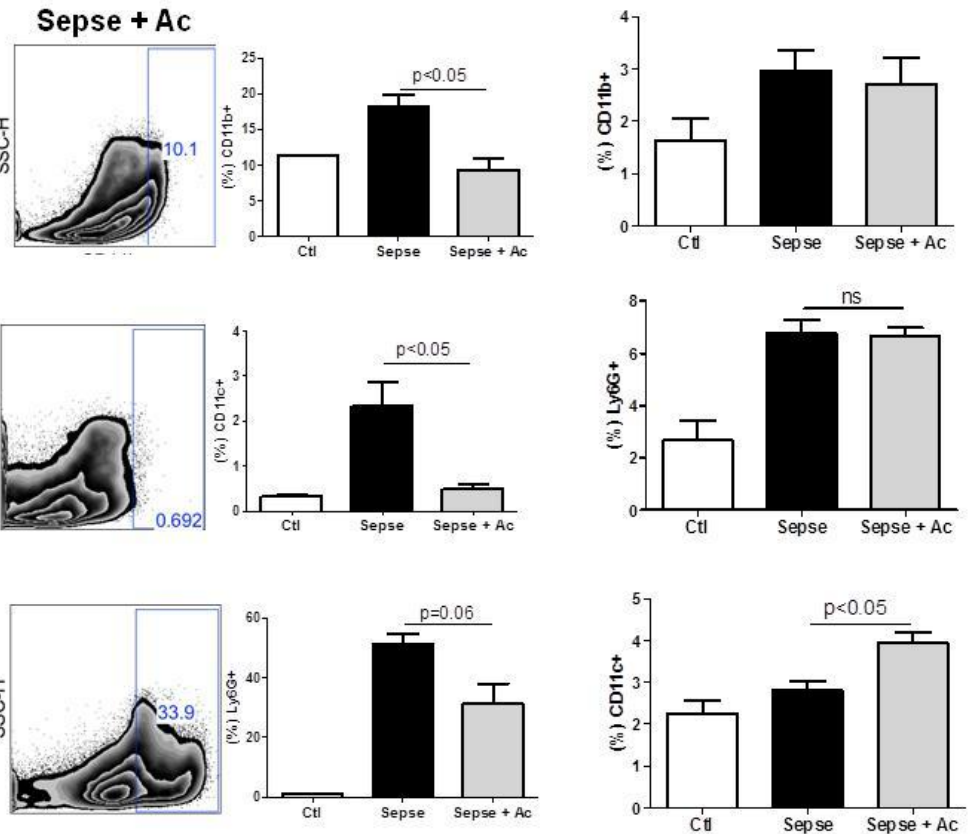

Figura 20. Níveis de citocinas sistemicamente e do infiltrado na cavidade peritoneal e no rim dos animais submetidos à sepse e tratados com acetato. (A) níveis de citocinas medidas no soro dos animais tratados com acetato. Avaliação da porcentagem de células positivas para neutrófilos (Ly6G), célula dendrítica (CD11c) e macrófago (CD11b) na cavidade peritoneal (B) e no rim (C) por citometria de fluxo nos animais submetidos à sepse e tratados com acetato. Ctl: animais controle; Sepse: grupo de animais com sepse; Sepse + Ac: grupo de animais com sepse e tratados com acetato. Teste T student.

Diante destes resultados, podemos concluir que o tratamento com acetato diminui o infiltrado inflamatório no peritônio, contribuindo para uma menor ativação das células do sistema imune,e consequente, menor inflamação, preservando a função renal e aumentando a sobrevida. 
5 DISCUSSÃo 
A LRA induzida pela isquemia e reperfusão tem uma complexa rede de eventos que envolvem um importante e bem conhecido processo inflamatório, que abrange as células tubulares epiteliais, as células endoteliais e as células imunes residentes. Além da alta taxa de mortalidade em pacientes em ambiente hospitalar, sua duração, extensão e os eventos adjacentes associados como a inflamação na LRA têm sido acreditados como fatores de risco para a DRC, perda do órgão e morte do paciente (4). Assim sendo, sua prevenção torna-se extremamente importante. Neste trabalho, nós investigamos se os AGCC, que possuem papel antiinflamatório e de inibidor de histona deacetilases, poderiam proteger ou melhorar a LRA secundária a duas causas distintas.

O tratamento com os AGCC, especialmente acetato, reduziu a lesão renal após a isquemia reperfusão. No melhor do nosso conhecimento, este é o primeiro estudo a demonstrar o papel protetor dos AGCC neste modelo de LRA. As concentrações empregadas neste estudo são equivalentes às encontradas no intestino (98). Outros estudos têm observado uma redução na lesão renal após o tratamento com os AGCC, em outros modelos como, nefrotoxicidade por antibiótico e nefropatia por contraste $(99,100)$. Outros ácidos graxos também já foram citados como protetores da LRA e da fibrose renal na lesão crônica $(87,101)$. Desse modo, os ácidos graxos são potenciais componentes a ser considerado no tratamento de doenças renais. A não proteção observada somente com uma dose de AGCC pode ser devida a sua rápida absorção, principalmente no intestino, onde eles são uma das principais fontes de energia para os colonócitos (102). A melhor proteção observada após o tratamento com o acetato poderia estar relacionada com a sua menor composição (dois carbonos), o que favoreceria a rápida entrada da molécula para ser metabolizada, enquanto que os outros AGCC precisam ser convertidos em moléculas precursoras. O tratamento com AGCC também tem sido mostrado como protetor na colite e em lesões de vias aéreas. (57, 103). Isso é de grande relevância, porque embora os AGCC sejam produzidos no intestino, principalmente no colon, eles podem alcançar a corrente sanguínea (62), ainda que a sua presença no rim não tenha sido descrita. De toda maneira, nós podemos especular que esta proteção observada poderia estar associada à ação dos AGCC diretamente no rim.

A inflamação e a apoptose são eventos de suma importância neste modelo e nós observamos que o tratamento com acetato inibiu os dois processos. Até certo ponto, este é um resultado esperado, visto que os AGCC têm sido previamente descritos ter propriedades antiinflamatórias. Uma pergunta que surge ao observar o resultado é se a redução da apoptose deveu-se pela diminuição da inflamação ou os AGCC também tem papéis antiapoptóticos. O que se tem descrito é que os AGCC, especialmente o propionato, podem induzir autofagia em uma estratégia de retardar a morte celular apoptótica mitocondrial (74). 
No rim Chien et al. mostraram a presença de genes relacionados com autofagia e de estruturas parecidas com autogassomos em modelo de isquemia reperfusão (104, 105). Entretanto, ainda não é totalmente aceito que a ocorrência de autofagia está relacionada com proteção, pois células submetidas a estresse tratadas com inibidor de autofagia observou-se prevenção da morte celular (105), sugerindo que autofagia induz morte celular nestas condições. Porém, dois recentes trabalhos que subtraíram moléculas relacionadas a autofagia especificamente em células epiteliais renais demonstraram que a ausência das moléculas ATG-5 e ATG-7 conferem maior susceptibilidade a morte celular pela IRI e por cisplatina $(106,107)$, o que reforça a tese de que a ocorrência de autofagia sob estresse também pode ser um mecanismo protetor para retardar o processo de apoptose das células renais. Em nosso trabalho, nós observamos um aumento da proteína ATG-7 nos animais submetidos à IRI e tratados com o acetato. Isto sugere que o menor grau de apoptose seja devido não somente a uma diminuição da inflamação, mas também a um aumento da autofagia nas células renais desses animais, preservando-as da morte. Desse modo, é plausível pensar que a indução da autofagia é um processo atuante nesta proteção observada com o tratamento com acetato.

Até hoje, dois são os mecanismos propostos pelos quais os AGCC podem atuar: como ligante para os receptores acoplados à proteína G, GPR41 e GPR43, ou como inibidor de histona deacetilase (HDAC). Este último acredita-se que deva ocorrer de maneira independente dos receptores (75). Neste trabalho, nós observamos níveis similares da expressão gênica de GPR41, enquanto os níveis de GPR43 estavam aumentados quando comparados os animais submetidos à IRI e os animais submetidos à IRI e tratados com acetato. Considerando a outra função atribuída aos AGCC, nós observamos uma redução da atividade de HDAC no tecido renal e uma modulação da expressão de genes que codificam enzimas relacionadas com modificações na cromatina. É importante mencionar que entre os genes diferencialmente expressos, nenhum deles codificava para HDAC, o que sugere que a ação dos AGCC como inibidores de HDAC seja somente ao nível proteico, e não gênico. Outros estudos também têm observado modulação da atividade de HDAC pelo acetato (108)

Ainda não está elucidado se a inibição da atividade de HDAC exercida pelos AGCC é dependente dos receptores GPR41 e GPR43. Recentemente, foi relatado que a inibição da atividade de HDAC pelo AGCC foi parcialmente dependente de GPR43 (109), mas outros também têm observado inibição da atividade de HDAC independente de GPR43 (110, 111). Embora nós tenhamos observado aumento na expressão do GPR43 no tecido renal após tratamento com acetato e IRI, sua expressão tem sido descrita como mínima ou nula no tecido renal $(68,112)$. Diante destes relatos, nós acreditamos que o tratamento com acetato possa modular o processo inflamatório através da regulação da modificação epigenética de 
maneira independente dos receptores GPRs. É salutar ressaltar que a inibição de histonas deacetilases acarreta em uma maior atividade das proteínas acetiltransferases, por conseguinte, acetilando tanto histonas quanto proteínas não histonas, o que acarreta em mudanças no nível de atividade dessas últimas $(111,113)$. Isto só faz aumentar a complexidade do uso dos AGCC como inibidores de HDAC. Outro interessante resultado obtido neste trabalho foi a observação do aumento da metilação global do DNA após o tratamento com acetato nos animais submetidos à IRI. Uma limitação desse achado é que esse ensaio é inespecífico, prevenindo qualquer distinção de quais regiões poderiam ser afetadas pela modificação no perfil de metilação. Visto que de maneira didática e geral, a presença da metilação está associada à repressão da transcrição gênica, a análise da região promotora de genes correlatos ou envolvidos na inflamação poderia ser interessante, visto que a maioria deles está com sua expressão diminuída após o tratamento com o acetato. Mas nós entendemos que estudos mais aprofundados deverão ser conduzidos a fim de esclarecer esta inter-relação entre metilação, atividade de HDAC e ativação de GPRs.

Para aprofundar o entendimento da ação protetora dos AGCCs, nós avaliamos o papel dos AGCC em células do sistema imune e em linhagens de células renais. Como observado in vivo, o tratamento com AGCC reduziu a expressão das moléculas co-estimuladoras CD40 e, em uma menor extensão, do CD80, em células dendríticas derivadas da medula óssea. Outros estudos também têm demonstrado redução tanto no desenvolvimento das DCs quando na ativação $(72,114,115)$. Além disso, nós observamos que a diminuição da expressão de moléculas co-estimuladoras após o tratamento das DCs com os AGCC foi funcional, pois somente com o tratamento das DCs foi possível inibir a proliferação de células T CD4+ e TCD8+.As DCs são as principais células que conectam a imunidade inata à adaptativa. Portanto, menor ativação de DC significa menor ativação linfocitária. Dados publicados pelo nosso grupo mostram que fatores relacionados à resposta de células $\mathrm{T}$ do tipo Th1 como as citocinas IFN- $\gamma$ e IL-12, bem como a ausência de células T reguladoras são importantes para o desenvolvimento da LRA (19, 20). Assim sendo, é admissível especular que menores frequências de DC ativadas poderiam induzir a uma menor ativação linfocitária in vivo. Nós também observamos que o tratamento com os AGCC é capaz de inibir a proliferação de esplenócitos in vitro, o que corrobora a ideia de menor ativação de DC, menor proliferação linfocitária. Esta inibição também foi verificada por Cavaglieri et al., (55). Visto que para os linfócitos diferenciarem em subtipos específicos deve ocorrer a expansão clonal, este resultado sugere que além da inibição de células dendríticas, os AGCC possam atuar inibindo a proliferação linfocitária in vivo, o que contribuiria para a melhora da lesão renal, ainda que não específica. Em um contexto mais amplo, esta inibição da proliferação de linfócitos com estímulo alogênico é especialmente importante no campo de transplantes, e já foi 
demonstrado que inibidores de histona deacetilases como os AGCC podem aumentar a sobrevida no transplante coração (113). Na literatura há relatos de que os AGCC podem induzir a diferenciação de linfócitos $\mathrm{T}$ dos subtipos Th1, Th17 e Treg in vivo e in vitro (109, 111, 116, 117). Estes resultados, em parte, vão de encontro com os nossos achados. Nós entendemos que essas diferenças devam ser em função das doses utilizadas nos diferentes estudos.

A isquemia na lesão renal é um importante evento que contribui para o desenvolvimento da lesão, porque junto a ela está a produção de ERO e a inflamação $(3,17)$. No transplante renal de doador falecido a LRA no transplante, chamada de DGF (Delayed Graft Function) tem sua ocorrência associada ao maior tempo de isquemia fria (118). Este tempo é no Brasil em média, de 24 horas, que é quando o órgão do doador permanece em baixas temperaturas até que seja realizada a escolha do receptor e o órgão, então, possa ser implantado no receptor. O tratamento com AGCC reduziu a ativação do NF-kb e a produção de NO em células tubulares epiteliais renais. Além disso, foi observada uma menor produção de ROS, menor translocação de HIF-1a e menor produção de lactato após hipóxia na presença dos AGCCs. Há uma associação direta entre a produção de lactato e a ativação de HIF-1a (119). A expressão dos GPRs no rim é mínima $(68,112)$, o que sugere que também nessas células o mecanismo de atuação dos AGCCs seria via inibição de HDAC, como observado in vivo. Outra possibilidade é que o tratamento com AGCC melhoraria a função mitocondrial após a isquemia, através do uso dos AGCC como fonte de energia e não como inibidor de HDAC, metabolizando estas moléculas. Esta ideia está respaldada pela observação de aumento nos níveis de DNA mitocondrial no tecido renal sujeito à IRI e tratado com acetato.

Observando nossos resultados in vivo e in vitro parece que o butirato exerceu um maior efeito in vitro do que in vivo. Nem todos os AGCC ligam-se nos mesmos receptores, como ratificado pelo estudo recentemente publicado para o receptor ORF78, o qual pode ser ativado por acetato e propionato, mas não pelo butirato e sua ativação via AGCC está envolvida na regulação da pressão sanguínea (120). Este novo achado permite levantar a hipótese se o acetato não estaria protegendo da LRA pela IRI através da ativação do Olr78. Se este for o caso, isso poderia explicar, ao menos para o tratamento com butirato, os melhores resultados observados in vitro, porque o Olr78 não é expresso em células epiteliais. De qualquer maneira, o tratamento com AGCC pode modular as vias envolvidas na lesão isquêmica e na inflamação em células tubulares renais submetidas à isquemia in vitro.

Por fim, nós tratamos os animais com bactérias produtoras de acetato e observamos melhora na função renal. Esta é uma estratégia alternativa, na qual nós conseguimos ratificar a proteção conferida pelo acetato no modelo de LRA induzido por IRI. $B$. longum, mas não $B$. 
adolescentis, foi reportada reduzir a morte dos animais em um modelo de infecção com $E$. coli enterohemorrágica, e esta proteção estava associada à produção de acetato (60). Em nosso trabalho, ambas as bactérias protegeram da LRA. Uma explicação encontrada para tal fato é que embora a bactéria $B$. adolescentis produza menos acetato comparada à $B$. longum, a quantidade produzida foi suficiente para proteger da LRA, mas outros estudos serão necessários para esclarecer esta questão. O que também se faz relevante mencionar é que a administração das bactérias nos animais foi realizada sem prévio tratamento dos animais com antibiótico, o que provavelmente prejudica a possibilidade dessas bactérias colonizarem os hospedeiros. Daí a ideia de se administrar o probiótico diariamente. A dificuldade de colonização não é exclusiva para esta espécie de bactéria. Estudos que realizaram este tipo de abordagem, seja administrando toda a microbiota, seja com a administração de somente uma espécie específica, têm feito tratamento prévio com antibiótico para aumentar as chances de colonização (121-123). De qualquer forma, futuros estudos são necessários para verificar se estas bactérias podem e, em quais condições, colonizariam o intestino.

A composição da microbiota intestinal está associada a diversos desfechos como obesidade, diabetes e doenças intestinais (124), mas agora começam a surgir associações da composição da microbiota e de seus metabólitos com doenças renais.

Animais germ-free são mais susceptíveis a LRA por IRI (51). A administração de acetato também é capaz de proteger da colite na ausência de microbiota (57), e a administração dos AGCC em camundongos selvagem também protege de outras enfermidades (99, 100, 103). Por outro lado, a DRC tem sido associada com quebra da barreira intestinal e mudança da microbiota intestinal, permitindo a entrada de bactérias patogênicas no epitélio intestinal e consequentemente na corrente sanguínea, o que pode exacerbar o processo inflamatório $(53,54)$. Aqui neste trabalho, nós demonstramos que produtos produzidos por bactérias da microbiota intestinal podem melhorar da LRA, colocando mais uma informação nesta complexa rede de interação que é microbiota, intestino e sistema imune e agora rim.

Apesar da importância da presença da microbiota em manter a homeostase intestinal e prevenir a inflamação, aparentemente um aumento na concentração dos AGCC poderia potencializar essa proteção. Já é conhecido que a microbiota intestinal pode mudar sua composição rapidamente mediante uma alteração na dieta alimentar (125). Aumento nos níveis de AGCC também pode ser alcançado através de mudanças na dieta e os probióticos poderiam ser investigados como estratégias terapêuticas em alguns contextos, reforçando a ideia que essas bactérias produtoras de acetato poderiam se tornar uma ferramenta no gerenciamento ou prevenção de processos inflamatórios. 
6 CONCLUSÕES 
Neste trabalho, nós podemos concluir que:

- O tratamento com os AGCC protege da LRA induzida pela lesão de isquemia e reperfusão;

- O tratamento com acetato diminui o processo apoptótico na IRI provavelmente por promoverem a autofagia, favorecendo a proliferação celular;

- O tratamento com acetato diminui a inflamação renal e sistêmica na IRI bem como a fluxo de células inflamatórias no rim;

- O efeito citoprotetor do acetato envolve processos epigenéticos no rim;

- A administração de bactérias produtoras de acetato protege os animais da lesão renal aguda induzida pela IRI;

-O tratamento com AGCC diminui a ativação e função das APCs bem como a proliferação linfocitária;

- Os AGCC atuam em células epiteliais renais, inibindo ativação de NF-кB e produção de NO frente a um estímulo inflamatório; e

- Os AGCC diminuem os efeitos da hipóxia em células epitelial renal, com menor ativação de HIF-1a.

Ainda, em relação ao modelo experimental de sepse, nós podemos concluir que:

- O tratamento com acetato protege da LRA secundária à sepse, por inibir o influxo de CE células imunes na cavidade peritoneal e a inflamação sistêmica.

Assim, os AGCC, mais especificamente o acetato, protegem da LRA de isquemia reperfusão e da secundária à sepse, por diminuir a inflamação provavelmente através da regulação de mecanismos epigenéticos. 


\section{REFERÊNCIAS}

1. Brown JR, Kramer RS, Coca SG, Parikh CR. Duration of acute kidney injury impacts long-term survival after cardiac surgery. The Annals of Thoracic Surgery. 2010;90(4):1142-8.

2. Moore EM, Bellomo R, Nichol A, Harley N, Macisaac C, Cooper DJ. The incidence of acute kidney injury in patients with traumatic brain injury. Renal Failure. 2010;32(9):10605.

3. Thadhani R, Pascual M, Bonventre JV. Acute renal failure. The New England Journal of Medicine. 1996;334(22):1448-60.

4. Rewa O, Bagshaw SM. Acute kidney injury-epidemiology, outcomes and economics. Nature Reviews Nephrology. 2014;10(4):193-207.

5. Lameire NH, Bagga A, Cruz D, De Maeseneer J, Endre Z, Kellum JA, et al. Acute kidney injury: an increasing global concern. The Lancet. 2013;382(9887):170-9.

6. Costa e Silva VT, de Castro I, Liano F, Muriel A, Rodriguez-Palomares JR, Yu L. Sequential evaluation of prognostic models in the early diagnosis of acute kidney injury in the intensive care unit. Kidney International. 2009;75(9):982-6.

7. Uchino S, Kellum JA, Bellomo R, Doig GS, Morimatsu H, Morgera S, et al. Acute renal failure in critically ill patients: a multinational, multicenter study. Jama. 2005;294(7):813-8.

8. Susantitaphong P, Cruz DN, Cerda J, Abulfaraj M, Alqahtani F, Koulouridis I, et al. World incidence of AKI: a meta-analysis. Clinical Journal of the American Society of Nephrology. 2013;8(9):1482-93.

9. Kosieradzki M, Rowiński W. Ischemia/reperfusion injury in kidney transplantation: mechanisms and prevention. Transplantation Proceedings. 2008;40(10):3279-88.

10. Schrier RW, Wang W, Poole B, Mitra A. Acute renal failure: definitions, diagnosis, pathogenesis, and therapy. The Journal of Clinical Investigation. 2004;114(1):5-14.

11. Tábara LC, Poveda J, Martin-Cleary C, Selgas R, Ortiz A, Sanchez-Niño MD. Mitochondria-targeted therapies for acute kidney injury. Expert Reviews in Molecular Medicine. 2014;16:e13.

12. Land WG. The role of postischemic reperfusion injury and other nonantigendependent inflammatory pathways in transplantation. Transplantation. 2005;79(5):505-14.

13. Perico N, Cattaneo D, Sayegh MH, Remuzzi G. Delayed graft function in kidney transplantation. The Lancet. 2004;364(9447):1814-27.

14. Dong X, Swaminathan S, Bachman LA, Croatt AJ, Nath KA, Griffin MD. Resident dendritic cells are the predominant TNF-secreting cell in early renal ischemia-reperfusion injury. Kidney International. 2007;71(7):619-28.

*De acordo com:

International Committee of Medical Journal Editors. [Internet]. Uniform requirements for manuscripts submitted to Biomedical Journal: sample references. [updated 2011 Jul 15]. Available from: http://www.icmje.org 
15. Awad AS, Rouse M, Huang L, Vergis AL, Reutershan J, Cathro HP, et al. Compartmentalization of neutrophils in the kidney and lung following acute ischemic kidney injury. Kidney International. 2009;75(7):689-98.

16. Burne-Taney MJ, Ascon DB, Daniels F, Racusen L, Baldwin W, Rabb H. B cell deficiency confers protection from renal ischemia reperfusion injury. The Journal of Immunology. 2003;171(6):3210-5.

17. Jang HR, Ko GJ, Wasowska BA, Rabb H. The interaction between ischemiareperfusion and immune responses in the kidney. Journal of Molecular Medicine. 2009;87(9):859-64.

18. Jo SK, Sung SA, Cho WY, Go KJ, Kim HK. Macrophages contribute to the initiation of ischaemic acute renal failure in rats. Nephrology, Dialysis, Transplantation. 2006;21(5):12319.

19. Monteiro RM, Camara NO, Rodrigues MM, Tzelepis F, Damiao MJ, Cenedeze MA, et al. A role for regulatory $\mathrm{T}$ cells in renal acute kidney injury. Transplant Immunology. 2009;21(1):50-5.

20. de Paiva VN, Monteiro RM, Marques Vde P, Cenedeze MA, Teixeira Vde P, dos Reis MA, et al. Critical involvement of Th1-related cytokines in renal injuries induced by ischemia and reperfusion. International Immunopharmacology. 2009;9(6):668-72.

21. Marques VP, Goncalves GM, Feitoza CQ, Cenedeze MA, Fernandes Bertocchi AP, Damiao MJ, et al. Influence of $\mathrm{TH} 1 / \mathrm{TH} 2$ switched immune response on renal ischemiareperfusion injury. Nephron Experimental Nephrology. 2006;104(1):e48-56.

22. Feitoza CQ, Camara NO, Pinheiro HS, Goncalves GM, Cenedeze MA, Pacheco-Silva A, et al. Cyclooxygenase 1 and/or 2 blockade ameliorates the renal tissue damage triggered by ischemia and reperfusion injury. International Immunopharmacology. 2005;5(1):79-84.

23. Wang PH, Campanholle G, Cenedeze MA, Feitoza CQ, Goncalves GM, Landgraf RG, et al. Bradykinin [corrected] $\mathrm{B} 1$ receptor antagonism is beneficial in renal ischemia-reperfusion injury. PloS One. 2008;3(8):e3050.

24. Shimizu MH, Araujo M, Borges SM, de Tolosa EM, Seguro AC. Influence of age and vitamin E on post-ischemic acute renal failure. Experimental Gerontology. 2004;39(5):82530.

25. de Araujo M, Andrade L, Coimbra TM, Rodrigues AC, Jr., Seguro AC. Magnesium supplementation combined with $\mathrm{N}$-acetylcysteine protects against postischemic acute renal failure. Journal of the American Society of Nephrology. 2005;16(11):3339-49.

26. Campanholle G, Landgraf RG, Goncalves GM, Paiva VN, Martins JO, Wang PH, et al. Lung inflammation is induced by renal ischemia and reperfusion injury as part of the systemic inflammatory syndrome. Inflammation Research. 2010;59(10):861-9.

27. Li X, Hassoun HT, Santora R, Rabb H. Organ crosstalk: the role of the kidney. Current Opinion in Critical Care. 2009;15(6):481-7.

28. Schrier RW, Wang W. Acute renal failure and sepsis. The New England Journal of Medicine. 2004;351(2):159-69. 
29. Schor N. Acute renal failure and the sepsis syndrome. Kidney International. 2002;61(2):764-76.

30. Cohen J. The immunopathogenesis of sepsis. Nature. 2002;420(6917):885-91.

31. Harada KM, Mandia-Sampaio EL, de Sandes-Freitas TV, Felipe CR, Park SI, PinheiroMachado PG, et al. Risk factors associated with graft loss and patient survival after kidney transplantation. Transplantation Proceedings. 2009;41(9):3667-70.

32. Yarlagadda SG, Coca SG, Formica RN, Jr., Poggio ED, Parikh CR. Association between delayed graft function and allograft and patient survival: a systematic review and metaanalysis. Nephrology, Dialysis, Transplantation. 2009;24(3):1039-47.

33. Goldstein SL, Devarajan P. Progression from acute kidney injury to chronic kidney disease: a pediatric perspective. Advances in Chronic Kidney Disease. 2008;15(3):278-83.

34. Liano F, Tenorio MT, Rodriguez-Mendiola N, Ponte B. Acute kidney injury as a risk factor for chronic kidney diseases in disadvantaged populations. Clinical Nephrology. 2010;74 Suppl 1:S89-94.

35. Yang L, Besschetnova TY, Brooks CR, Shah JV, Bonventre JV. Epithelial cell cycle arrest in G2/M mediates kidney fibrosis after injury. Nature Medicine. 2010;16(5):535-43, 1p following 143 .

36. Ko GJ, Grigoryev DN, Linfert D, Jang HR, Watkins T, Cheadle C, et al. Transcriptional analysis of kidneys during repair from AKI reveals possible roles for NGAL and KIM-1 as biomarkers of AKI-to-CKD transition. American Journal of Physiology. 2010;298(6):F147283.

37. Liu Y. Renal fibrosis: new insights into the pathogenesis and therapeutics. Kidney International. 2006;69(2):213-7.

38. Venkatachalam MA, Griffin KA, Lan R, Geng H, Saikumar P, Bidani AK. Acute kidney injury: a springboard for progression in chronic kidney disease. American Journal of Physiology. 2010;298(5):F1078-94.

39. Bedi S, Vidyasagar A, Djamali A. Epithelial-to-mesenchymal transition and chronic allograft tubulointerstitial fibrosis. Transplantation Reviews. 2008;22(1):1-5.

40. Jo SK, Rosner MH, Okusa MD. Pharmacologic treatment of acute kidney injury: why drugs haven't worked and what is on the horizon. Clinical Journal of the American Society of Nephrology. 2007;2(2):356-65.

41. Cerf-Bensussan N, Gaboriau-Routhiau V. The immune system and the gut microbiota: friends or foes? Nature Reviews Immunology.10(10):735-44.

42. Elinav E, Strowig T, Kau AL, Henao-Mejia J, Thaiss CA, Booth CJ, et al. NLRP6 inflammasome regulates colonic microbial ecology and risk for colitis. Cell.145(5):745-57.

43. Round JL, Mazmanian SK. Inducible Foxp3+ regulatory T-cell development by a commensal bacterium of the intestinal microbiota. Proceedings of the National Academy of Sciences of the United States of America.107(27):12204-9. 
44. Atarashi K, Tanoue T, Shima T, Imaoka A, Kuwahara T, Momose Y, et al. Induction of colonic regulatory T cells by indigenous Clostridium species. Science.331(6015):337-41.

45. Ivanov, II, Atarashi K, Manel N, Brodie EL, Shima T, Karaoz U, et al. Induction of intestinal Th17 cells by segmented filamentous bacteria. Cell. 2009;139(3):485-98.

46. Vaishnava S, Yamamoto M, Severson KM, Ruhn KA, Yu X, Koren O, et al. The antibacterial lectin RegIIIgamma promotes the spatial segregation of microbiota and host in the intestine. Science.334(6053):255-8.

47. Salzman NH, Ghosh D, Huttner KM, Paterson Y, Bevins CL. Protection against enteric salmonellosis in transgenic mice expressing a human intestinal defensin. Nature. 2003;422(6931):522-6.

48. Hooper LV, Littman DR, Macpherson AJ. Interactions between the microbiota and the immune system. Science.336(6086):1268-73.

49. Siener R, Bangen U, Sidhu H, Hönow R, von Unruh G, Hesse A. The role of Oxalobacter formigenes colonization in calcium oxalate stone disease. Kidney International. 2013;83(6):1144-9.

50. Kaufman DW, Kelly JP, Curhan GC, Anderson TE, Dretler SP, Preminger GM, et al. Oxalobacter formigenes may reduce the risk of calcium oxalate kidney stones. Journal of the American Society of Nephrology. 2008;19(6):1197-203.

51. Jang HR, Gandolfo MT, Ko GJ, Satpute S, Racusen L, Rabb H. Early exposure to germs modifies kidney damage and inflammation after experimental ischemia-reperfusion injury. American Journal of Physiology Renal Physiology. 2009;297(5):F1457-65.

52. McCarthy DD, Kujawa J, Wilson C, Papandile A, Poreci U, Porfilio EA, et al. Mice overexpressing BAFF develop a commensal flora-dependent, IgA-associated nephropathy. The Journal of Clinical Investigation. 2011;121(10):3991-4002.

53. Anders HJ, Andersen K, Stecher B. The intestinal microbiota, a leaky gut, and abnormal immunity in kidney disease. Kidney International. 2013;83(6):1010-6.

54. Vaziri ND. CKD impairs barrier function and alters microbial flora of the intestine: a major link to inflammation and uremic toxicity. Current Opinion in Nephrology and Hypertension. 2012;21(6):587-92.

55. Cavaglieri CR, Nishiyama A, Fernandes LC, Curi R, Miles EA, Calder PC. Differential effects of short-chain fatty acids on proliferation and production of pro- and antiinflammatory cytokines by cultured lymphocytes. Life sciences. 2003;73(13):1683-90.

56. Fukuda S, Toh H, Hase K, Oshima K, Nakanishi Y, Yoshimura K, et al. Bifidobacteria can protect from enteropathogenic infection through production of acetate. Nature.469(7331):543-7.

57. Maslowski KM, Vieira AT, Ng A, Kranich J, Sierro F, Yu D, et al. Regulation of inflammatory responses by gut microbiota and chemoattractant receptor GPR43. Nature. 2009;461(7268):1282-6.

58. Singh N, Thangaraju M, Prasad PD, Martin PM, Lambert NA, Boettger T, et al. Blockade of dendritic cell development by bacterial fermentation products butyrate and 
propionate through a transporter (Slc5a8)-dependent inhibition of histone deacetylases. The Journal of Biological Chemistry.285(36):27601-8.

59. Wang H, Zhang W, Zuo L, Zhu W, Wang B, Li Q, et al. Bifidobacteria may be beneficial to intestinal microbiota and reduction of bacterial translocation in mice following ischaemia and reperfusion injury. British Journal of Nutrition. 2013;109(11):1990-8.

6o. Fukuda S, Toh H, Hase K, Oshima K, Nakanishi Y, Yoshimura K, et al. Bifidobacteria can protect from enteropathogenic infection through production of acetate. Nature. 2011;469(7331):543-7.

61. Macfarlane GT, Macfarlane S. Fermentation in the human large intestine: its physiologic consequences and the potential contribution of prebiotics. Journal of Clinical Gastroenterology. 2011;45 Suppl:S120-7.

62. Pomare EW, Branch WJ, Cummings JH. Carbohydrate fermentation in the human colon and its relation to acetate concentrations in venous blood. The Journal of Clinical Investigation. 1985;75(5):1448-54.

63. Brown AJ, Goldsworthy SM, Barnes AA, Eilert MM, Tcheang L, Daniels D, et al. The Orphan G protein-coupled receptors GPR41 and GPR43 are activated by propionate and other short chain carboxylic acids. The Journal of Biological Chemistry. 2003;278(13):113129 .

64. Covington DK, Briscoe CA, Brown AJ, Jayawickreme CK. The G-protein-coupled receptor 40 family (GPR40-GPR43) and its role in nutrient sensing. Biochemical Society Transactions. 2006;34(Pt 5):770-3.

65. Le Poul E, Loison C, Struyf S, Springael JY, Lannoy V, Decobecq ME, et al. Functional characterization of human receptors for short chain fatty acids and their role in polymorphonuclear cell activation. The Journal of Biological Chemistry. 2003;278(28):25481-9.

66. Millar RP, Newton CL. The year in G protein-coupled receptor research. Molecular Endocrinology.2010;24(1):261-74.

67. Hirasawa A, Itsubo C, Sadakane K, Hara T, Shinagawa S, Koga H, et al. Production and characterization of a monoclonal antibody against GPR40 (FFAR1; free fatty acid receptor 1). Biochemical and Biophysical Research Communications.2008;365(1):22-8.

68. Nilsson NE, Kotarsky K, Owman C, Olde B. Identification of a free fatty acid receptor, FFA2R, expressed on leukocytes and activated by short-chain fatty acids. Biochemical Biophysical Research Communications.2003;303(4):1047-52.

69. Vinolo MA, Hatanaka E, Lambertucci RH, Newsholme P, Curi R. Effects of short chain fatty acids on effector mechanisms of neutrophils. Cell Biochemistry and Function. 2009;27(1):48-55.

70. Vinolo MA, Rodrigues HG, Hatanaka E, Hebeda CB, Farsky SH, Curi R. Short-chain fatty acids stimulate the migration of neutrophils to inflammatory sites. Clinical Science. 2009;117(9):331-8.

71. Vinolo MA, Ferguson GJ, Kulkarni S, Damoulakis G, Anderson K, Bohlooly YM, et al. SCFAs induce mouse neutrophil chemotaxis through the GPR43 receptor. PloS One. 2011;6(6):e21205. 
72. Singh N, Thangaraju M, Prasad PD, Martin PM, Lambert NA, Boettger T, et al. Blockade of dendritic cell development by bacterial fermentation products butyrate and propionate through a transporter (Slc5a8)-dependent inhibition of histone deacetylases. The Journal of Biological Chemistry. 2010;285(36):27601-8.

73. Zaibi MS, Stocker CJ, O'Dowd J, Davies A, Bellahcene M, Cawthorne MA, et al. Roles of GPR41 and GPR43 in leptin secretory responses of murine adipocytes to short chain fatty acids. FEBS letters. 2010;584(11):2381-6.

74. Tang Y, Chen Y, Jiang H, Nie D. Short-chain fatty acids induced autophagy serves as an adaptive strategy for retarding mitochondria-mediated apoptotic cell death. Cell Death and Differentiation. 2011;18(4):602-18.

75. Vinolo MA, Rodrigues HG, Nachbar RT, Curi R. Regulation of inflammation by short chain fatty acids. Nutrients. 2011;3(10):858-76.

76. Donohoe DR, Collins LB, Wali A, Bigler R, Sun W, Bultman SJ. The Warburg effect dictates the mechanism of butyrate-mediated histone acetylation and cell proliferation. Molecular Cell. 2012;48(4):612-26.

77. Fox CJ, Hammerman PS, Thompson CB. Fuel feeds function: energy metabolism and the T-cell response. Nature Reviews Immunology. 2005;5(11):844-52.

78. Rubinsztein DC, Codogno P, Levine B. Autophagy modulation as a potential therapeutic target for diverse diseases. Nature reviews. Drug Discovery.2012;11(9):709-30.

79. Periyasamy-Thandavan S, Jiang M, Schoenlein P, Dong Z. Autophagy: molecular machinery, regulation, and implications for renal pathophysiology. American journal of Physiology. 2009;297(2):F244-56.

8o. Pyo JO, Nah J, Jung YK. Molecules and their functions in autophagy. Experimental \& Molecular Medicine. 2012;44(2):73-80.

81. Sina C, Gavrilova O, Forster M, Till A, Derer S, Hildebrand F, et al. G protein-coupled receptor 43 is essential for neutrophil recruitment during intestinal inflammation. The Journal of Immunology. 2009;183(11):7514-22.

82. Cox MA, Jackson J, Stanton M, Rojas-Triana A, Bober L, Laverty M, et al. Short-chain fatty acids act as antiinflammatory mediators by regulating prostaglandin E(2) and cytokines. World Journal of Gastroenterology. 2009;15(44):5549-57.

83. Tedelind S, Westberg F, Kjerrulf M, Vidal A. Anti-inflammatory properties of the short-chain fatty acids acetate and propionate: a study with relevance to inflammatory bowel disease. World Journal of Gastroenterology. 2007;13(20):2826-32.

84. Kwon HS, Yang EH, Lee SH, Yeon SW, Kang BH, Kim TY. Rapid identification of potentially probiotic Bifidobacterium species by multiplex PCR using species-specific primers based on the region extending from 16S rRNA through 23S rRNA. FEMS Microbiol Lett. 2005;250(1):55-62.

85. Hillegass LM, Griswold DE, Brickson B, Albrightson-Winslow C. Assessment of myeloperoxidase activity in whole rat kidney. Journal of Pharmacological Methods. 1990;24(4):285-95. 
86. Sharma S, De Carvalho DD, Jeong S, Jones PA, Liang G. Nucleosomes containing methylated DNA stabilize DNA methyltransferases $3 \mathrm{~A} / 3 \mathrm{~B}$ and ensure faithful epigenetic inheritance. PLoS Genetics. 2011;7(2):e1001286.

87. Liu H, Jia Z, Soodvilai S, Guan G, Wang MH, Dong Z, et al. Nitro-oleic acid protects the mouse kidney from ischemia and reperfusion injury. American Journal of Physiology. 2008;295(4):F942-9.

88. Zhang L, Jin S, Wang C, Jiang R, Wan J. Histone deacetylase inhibitors attenuate acute lung injury during cecal ligation and puncture-induced polymicrobial sepsis. World Journal of Surgery. 2010;34(7):1676-83.

89. Zhang LT, Yao YM, Lu JQ, Yan XJ, Yu Y, Sheng ZY. Sodium butyrate prevents lethality of severe sepsis in rats. Shock (Augusta, Ga. 2007;27(6):672-7.

90. Nishikori M. Classical and Alternative NF-kB Activation Pathways and Their Roles in Lymphoid Malignancies. Journal of Clinical and Experimental Hematopathology. 2005;45(1):15-24.

91. Leemans JC, Stokman G, Claessen N, Rouschop KM, Teske GJ, Kirschning CJ, et al. Renal-associated TLR2 mediates ischemia/reperfusion injury in the kidney. The Journal of clinical investigation. 2005;115(10):2894-903.

92. Pulskens WP, Teske GJ, Butter LM, Roelofs JJ, van der Poll T, Florquin S, et al. Tolllike receptor-4 coordinates the innate immune response of the kidney to renal ischemia/reperfusion injury. PloS One. 2008;3(10):e3596.

93. Wu H, Chen G, Wyburn KR, Yin J, Bertolino P, Eris JM, et al. TLR4 activation mediates kidney ischemia/reperfusion injury. The Journal of Clinical Investigation. 2007;117(10):2847-59.

94. Wu H, Ma J, Wang P, Corpuz TM, Panchapakesan U, Wyburn KR, et al. HMGB1 contributes to kidney ischemia reperfusion injury. Journal of the American Society of Nephrology. 2010;21(11):1878-90.

95. Yonezawa T, Kobayashi Y, Obara Y. Short-chain fatty acids induce acute phosphorylation of the p38 mitogen-activated protein kinase/heat shock protein 27 pathway via GPR43 in the MCF-7 human breast cancer cell line. Cellular Signalling. 2007;19(1):18593 .

96. Lee JW, Bae SH, Jeong JW, Kim SH, Kim KW. Hypoxia-inducible factor (HIF1)alpha: its protein stability and biological functions. Experimental \& Molecular Medicine. 2004;36(1):1-12.

97. Safronova O, Morita I. Transcriptome remodeling in hypoxic inflammation. Journal of Dental Research. 2010;89(5):430-44.

98. Cummings JH, Pomare EW, Branch WJ, Naylor CP, Macfarlane GT. Short chain fatty acids in human large intestine, portal, hepatic and venous blood. Gut. 1987;28(10):1221-7.

99. Sun X, Zhang B, Hong X, Zhang X, Kong X. Histone deacetylase inhibitor, sodium butyrate, attenuates gentamicin-induced nephrotoxicity by increasing prohibitin protein expression in rats. European Journal of Pharmacology. 2013;707(1-3):147-54. 
100. Machado RA, Constantino LeS, Tomasi CD, Rojas HA, Vuolo FS, Vitto MF, et al. Sodium butyrate decreases the activation of NF- $\kappa B$ reducing inflammation and oxidative damage in the kidney of rats subjected to contrast-induced nephropathy. Nephrology, Dialysis, Transplantation. 2012;27(8):3136-40.

101. Van Beneden K, Geers C, Pauwels M, Mannaerts I, Verbeelen D, van Grunsven LA, et al. Valproic acid attenuates proteinuria and kidney injury. Journal of the American Society of Nephrology. 2011;22(10):1863-75.

102. Agarwal VP, Schimmel EM. Diversion colitis: a nutritional deficiency syndrome? Nutrition Reviews. 1989;47(9):257-61.

103. Trompette A, Gollwitzer ES, Yadava K, Sichelstiel AK, Sprenger N, Ngom-Bru C, et al. Gut microbiota metabolism of dietary fiber influences allergic airway disease and hematopoiesis. Nature Medicine. 2014;20(2):159-66.

104. Chien CT, Shyue SK, Lai MK. Bcl-xL augmentation potentially reduces ischemia/reperfusion induced proximal and distal tubular apoptosis and autophagy. Transplantation. 2007;84(9):1183-90.

105. Suzuki C, Isaka Y, Takabatake Y, Tanaka H, Koike M, Shibata M, et al. Participation of autophagy in renal ischemia/reperfusion injury. Biochemical and Biophysical Research Communications. 2008;368(1):100-6.

106. Jiang M, Wei Q, Dong G, Komatsu M, Su Y, Dong Z. Autophagy in proximal tubules protects against acute kidney injury. Kidney International. 2012;82(12):1271-83.

107. Liu S, Hartleben B, Kretz O, Wiech T, Igarashi P, Mizushima N, et al. Autophagy plays a critical role in kidney tubule maintenance, aging and ischemia-reperfusion injury. Autophagy. 2012;8(5):826-37.

108. Tan J, McKenzie C, Potamitis M, Thorburn AN, Mackay CR, Macia L. The role of short-chain fatty acids in health and disease. Advances in Immunology. 2014;121:91-119.

109. Smith PM, Howitt MR, Panikov N, Michaud M, Gallini CA, Bohlooly YM, et al. The microbial metabolites, short-chain fatty acids, regulate colonic Treg cell homeostasis. Science. 2013;341(6145):569-73.

110. Aoyama M, Kotani J, Usami M. Butyrate and propionate induced activated or nonactivated neutrophil apoptosis via HDAC inhibitor activity but without activating GPR41/GPR-43 pathways. Nutrition. 2010;26(6):653-61.

111. Park J, Kim M, Kang SG, Jannasch AH, Cooper B, Patterson J, et al. Short-chain fatty acids induce both effector and regulatory $\mathrm{T}$ cells by suppression of histone deacetylases and regulation of the mTOR-S6K pathway. Mucosal Immunology. 2014.

112. Kimura I, Ozawa $\mathrm{K}$, Inoue $\mathrm{D}$, Imamura $\mathrm{T}$, Kimura $\mathrm{K}$, Maeda $\mathrm{T}$, et al. The gut microbiota suppresses insulin-mediated fat accumulation via the short-chain fatty acid receptor GPR43. Nature Communications. 2013;4:1829.

113. Tao R, de Zoeten EF, Ozkaynak E, Chen C, Wang L, Porrett PM, et al. Deacetylase inhibition promotes the generation and function of regulatory $\mathrm{T}$ cells. Nature Medicine. 2007;13(11):1299-307. 
114. Nascimento CR, Freire-de-Lima CG, da Silva de Oliveira A, Rumjanek FD, Rumjanek VM. The short chain fatty acid sodium butyrate regulates the induction of CD1a in developing dendritic cells. Immunobiology. 2011;216(3):275-84.

115. Wang B, Morinobu A, Horiuchi M, Liu J, Kumagai S. Butyrate inhibits functional differentiation of human monocyte-derived dendritic cells. Cellular Immunology. 2008;253(1-2):54-8.

116. Furusawa Y, Obata Y, Fukuda S, Endo TA, Nakato G, Takahashi D, et al. Commensal microbe-derived butyrate induces the differentiation of colonic regulatory $\mathrm{T}$ cells. Nature. 2013;504(7480):446-50.

117. Arpaia N, Campbell C, Fan X, Dikiy S, van der Veeken J, deRoos P, et al. Metabolites produced by commensal bacteria promote peripheral regulatory $\mathrm{T}$-cell generation. Nature. 2013;504(7480):451-5.

118. van der Vliet JA, Warle MC, Cheung CL, Teerenstra S, Hoitsma AJ. Influence of prolonged cold ischemia in renal transplantation. Clinical Transplantation. 2011;25(6):E6126.

119. Sonveaux P, Copetti T, De Saedeleer CJ, Vegran F, Verrax J, Kennedy KM, et al. Targeting the lactate transporter MCT1 in endothelial cells inhibits lactate-induced HIF-1 activation and tumor angiogenesis. PLoS One. 2012;7(3):e33418.

120. Pluznick JL, Protzko RJ, Gevorgyan H, Peterlin Z, Sipos A, Han J, et al. Olfactory receptor responding to gut microbiota-derived signals plays a role in renin secretion and blood pressure regulation. Proceedings of the National Academy of Sciences of the United States of America. 2013;110(11):4410-5.

121. Vijay-Kumar M, Aitken JD, Carvalho FA, Cullender TC, Mwangi S, Srinivasan S, et al. Metabolic syndrome and altered gut microbiota in mice lacking Toll-like receptor 5 . Science. 2010;328(5975):228-31.

122. Elinav E, Strowig T, Kau AL, Henao-Mejia J, Thaiss CA, Booth CJ, et al. NLRP6 inflammasome regulates colonic microbial ecology and risk for colitis. Cell. 2011;145(5):74557.

123. Devkota S, Wang Y, Musch MW, Leone V, Fehlner-Peach H, Nadimpalli A, et al. Dietary-fat-induced taurocholic acid promotes pathobiont expansion and colitis in Il10-/mice. Nature. 2012;487(7405):104-8.

124. Honda K, Littman DR. The microbiome in infectious disease and inflammation. Annual Review of Immunology. 2012;30:759-95.

125. David LA, Maurice CF, Carmody RN, Gootenberg DB, Button JE, Wolfe BE, et al. Diet rapidly and reproducibly alters the human gut microbiome. Nature. 2014;505(7484):559-63. 
APÊNDICE - Trabalhos publicados no doutorado 
Trabalhos publicados de primeiro autor

1) Andrade-Oliveira V, Campos EF, Goncalves-Primo A, Grenzi PC, Medina-Pestana JO, Tedesco-Silva H, Gerbase-DeLima M. TLR4 mRNA levels as tools to estimate risk for early posttransplantation kidney graft dysfunction. Transplantation. 2012 Sep 27;94(6):589-95.

2) Andrade-Oliveira V, Amano MT, Correa-Costa M, Castoldi A, Felizardo RJF, de Almeida DC, Bassi EJ, Moraes-Vieira PM, Hiyane MI, Rodas ACD, Peron JPS, Aguiar CF, Reis MA, Ribeiro WR, Valduga CJ, Curi R, Vinolo MA, Ferreira CM, Câmara NO. Gut bacteria products prevent acute kidney injury induced by ischemia-reperfusion. Journal of the American Society of Nephrology. Aceito para publicação (segunda página a seguir)

Trabalhos publicados em colaboração

1) Miyagi MY, Seelaender M, Castoldi A, de Almeida DC, Bacurau AV, Andrade-Oliveira V, Enjiu LM, Pisciottano M, Hayashida CY, Hiyane MI, Brum PC, Camara NO, Amano MT. Long-Term Aerobic Exercise Protects against Cisplatin-Induced Nephrotoxicity by Modulating the Expression of IL-6 and HO-1.PLoS One. 2014 Oct 1;9(10):e108543.

2) Correa-Costa M, Braga TT, Felizardo RJ, Andrade-Oliveira V, Perez KR, Cuccovia IM, Hiyane MI, da Silva JS, Câmara NO.Macrophage trafficking as key mediator of adenineinduced kidney injury. Mediators of Inflammation. 2014; 2014:291024.

3) Goncalves-Primo A, Mourão TB, Andrade-Oliveira V, Campos EF, Medina-Pestana JO, Tedesco-Silva H, Gerbase-DeLima M. Investigation of apoptosis-related gene expression levels in preimplantation biopsies as predictors of delayed kidney graft function.Transplantation. 2014 Jun 27;97(12):1260-5.

4) Correa-Costa M, Andrade-Oliveira V, Braga TT, Castoldi A, Aguiar CF, Origassa CS, Rodas AC, Hiyane MI, Malheiros DM, Rios FJ, Jancar S, Câmara NO Activation of plateletactivating factor receptor exacerbates renal inflammation and promotes fibrosis. Laboratory Investigation. 2014 Apr;94(4):455-66.

5) Moraes-Vieira PM, Larocca RA, Bassi EJ, Peron JP, Andrade-Oliveira V, Wasinski F, Araujo R, Thornley T, Quintana FJ, Basso AS, Strom TB, Câmara NO.Leptin deficiency 
impairs maturation of dendritic cells and enhances induction of regulatory $\mathrm{T}$ and Th17 cells. European Journal of Immunology. 2014 Mar;44(3):794-806.

Trabalhos submetidos para publicação

Almeida CS, Andrade-Oliveira V, Jacysyn JF, Câmara NO, Faquim-Mauro EL. CROTOXIN FROM Crotalus durissus terrificus IS ABLE TO DOWN-MODULATE acute intestinal inflammation in mice. Submetido a Plos One. 
BASIC RESEARCH www.jasn.org

\title{
Gut Bacteria Products Prevent AKI Induced by Ischemia-Reperfusion
}

\author{
Vinicius Andrade-Oliveira, ${ }^{*}$ Mariane T. Amano, ${ }^{*}$ Matheus Correa-Costa, ${ }^{*}$ Angela Castoldi, ${ }^{*}$ \\ Raphael J.F. Felizardo, ${ }^{\dagger}$ Danilo C. de Almeida, ${ }^{\dagger}{ }^{2}$ Enio J. Bassi, ${ }^{\star}$ Pedro M. Moraes-Vieira, ${ }^{\dagger}$ \\ Meire I. Hiyane, ${ }^{\dagger}$ Andrea C.D. Rodas, ${ }^{\dagger}$ Jean P.S. Peron, ${ }^{\dagger}$ Cris F. Aguiar, ${ }^{\dagger}$ Marlene A. Reis, ${ }^{\ddagger}$ \\ Willian R. Ribeiro, ${ }^{\S}$ Claudete J. Valduga, ${ }^{\S}$ Rui Curi," Marco Aurelio Vinolo," \\ Caroline M. Ferreira," and Niels Olsen Saraiva Câmara* ${ }^{\star}$ \\ *Laboratory of Transplantation Immunobiology, Department of Immunology, Institute of Biomedical Sciences IV, University \\ of São Paulo, São Paulo, Brazil; 'Laboratory of Clinical and Experimental Immunology, Nephrology Division, Federal \\ University of São Paulo, São Paulo, Brazil; ${ }^{\ddagger}$ Division of Pathology, Universidade Federal do Triângulo Mineiro, Uberaba, \\ Brazil; §Department of Pharmacy and Biotechnology, Universidade Anhanguera de São Paulo UNIAN-SP, São Paulo, Brazil; \\ and "Department of Physiology and Biophysics, Institute of Biomedical Sciences IV, University of São Paulo, São Paulo, Brazil
}

\begin{abstract}
Short-chain fatty acids (SCFAs) are fermentation end products produced by the intestinal microbiota and have anti-inflammatory and histone deacetylase-inhibiting properties. Recently, a dual relationship between the intestine and kidneys has been unraveled. Therefore, we evaluated the role of SCFA in an AKI model in which the inflammatory process has a detrimental role. We observed that therapy with the three main SCFAs (acetate, propionate, and butyrate) improved renal dysfunction caused by injury. This protection was associated with low levels of local and systemic inflammation, oxidative cellular stress, cell infiltration/activation, and apoptosis. However, it was also associated with an increase in autophagy. Moreover, SCFAs inhibited histone deacetylase activity and modulated the expression levels of enzymes involved in chromatin modification. In vitro analyses showed that SCFAs modulated the inflammatory process, decreasing the maturation of dendritic cells and inhibiting the capacity of these cells to induce $C D 4^{+}$and $C D 8^{+} \mathrm{T}$ cell proliferation. Furthermore, SCFAs ameliorated the effects of hypoxia in kidney epithelial cells by improving mitochondrial biogenesis. Notably, mice treated with acetate-producing bacteria also had better outcomes after AKI. Thus, we demonstrate that SCFAs improve organ function and viability after an injury through modulation of the inflammatory process, most likely via epigenetic modification.
\end{abstract}

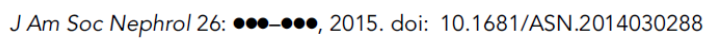

AKI is an inflammatory process frequently observed in hospitalized patients. AKI is associated with the development of CKD and causes distress to the patient. ${ }^{1,2} \mathrm{AKI}$ induced by ischemia and reperfusion injury (IRI) is closely linked to the activation of tubular epithelial and endothelial cells by endogenous danger signals released after cell stress and death due to enhanced production of reactive oxygen species (ROS), among other inducers. ${ }^{3}$ Additionally, IRI involves the migration and activation of innate and adaptive immune cells into the kidneys.

Increased ROS production disrupts the ratio of oxidant/antioxidant enzymes, leading to mitochon- drial-mediated apoptotic cell death. Activation of endothelial cells enhances adhesion molecule expression, which recruits immune cells, contributing to ROS production. ${ }^{3}$ Similarly, kidney tubular

Received March 19, 2014. Accepted October 1, 2014.

Published online ahead of print. Publication date available at www.jasn.org

Correspondence: Dr. Niels Olsen Saraiva Câmara, Department of Immunology, Institute of Biomedical Sciences, University of São Paulo, Av. Prof. Lineu Prestes, 1730 Cid. Universitaria, São Paulo 05508-000, Brazil. Email: niels@icb.usp.br

Copyright $\odot 2015$ by the American Society of Nephrology 